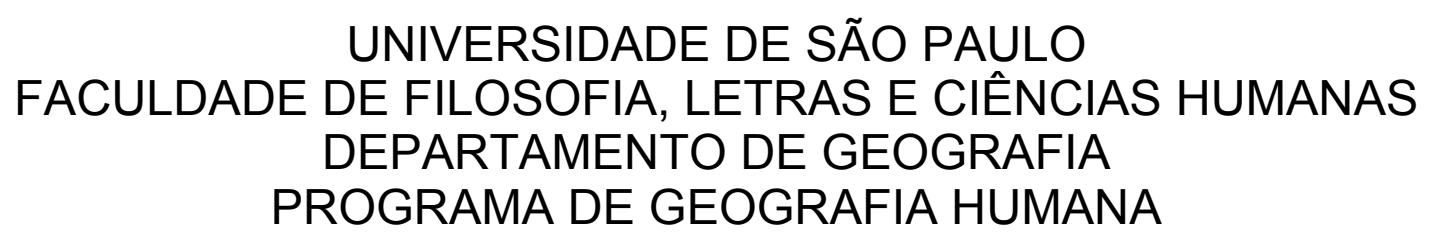

\title{
O PAPEL DOS PROCESSOS DE PARTICIPAÇÃO POPULAR NA GESTÃO MUNICIPAL: ESTUDO DO ORÇAMENTO PARTICIPATIVO NO MUNICÍPIO DE RIO CLARO/SP
}

Fabiane Pizzirani 
UNIVERSIDADE DE SÃO PAULO

FACULDADE DE FILOSOFIA, LETRAS E CIÊNCIAS HUMANAS

DEPARTAMENTO DE GEOGRAFIA

PROGRAMA DE PÓS-GRADUAÇÃO EM GEOGRAFIA HUMANA

\section{O PAPEL DOS PROCESSOS DE PARTICIPAÇÃO POPULAR NA GESTÃO MUNICIPAL: ESTUDO DO ORÇAMENTO PARTICIPATIVO NO MUNICÍPIO DE RIO CLARO/SP}

Fabiane Pizzirani

Dissertação apresentada ao Programa de PósGraduação em Geografia Humana, do Departamento de Geografia da Faculdade de Filosofia, Letras e Ciências Humanas da Universidade de São Paulo, para obtenção do título de Mestre em Geografia.

Orientadora: Profa. Dra. Ana Fani Alessandri Carlos 


\section{Agradecimentos}

O percurso desta dissertação acompanhou o percurso de minha vida. Meus agradecimentos são àqueles que me acompanharam neste caminho...

Primeiramente agradeço à Profa. Dra. Ana Fani Alessandri Carlos por ter me aceitado como orientanda, pelos puxões de orelha nas horas certas, pelos conselhos e orientações para a dissertação e para a vida e também por sua inestimável contribuição para a geografia.

Contribuição importante à esta dissertação foi dada pela Profa. Dra. Arlete Moysés Rodrigues, que aceitou participar de meu Exame de Qualificação e trouxe importantes questões e sugestões ao trabalho, reflexo de sua grande contribuição à ciência geográfica e à gestão das cidades.

À Profa. Dra. Silvana Maria Pintaudi cabe todo meu agradecimento, pois é grande responsável pelo meu desenvolvimento acadêmico, pela minha entrada na pósgraduação, graças ao seu permanente incentivo para o desenvolvimento desta pesquisa. É também responsável por grande parte do que eu sou hoje, profissionalmente e academicamente. Parte fundamental de minha vida.

Agradeço à todos os companheiros de trabalho da Prefeitura Municipal de Rio Claro, onde tive minha primeira experiência profissional como geógrafa. À todos que contribuiram para a obtenção de informações e para o debate. Em especial ao amigo Darci Cesar de Lima, que sempre me apoiou e me auxiliou em todos meus passos.

Um ano na França, um ano de novas experiências pessoais e profissionais, possíveis pela ajuda do Prof. Dr. Yves Sintomer, da Universidade Paris VIII, que me ajudou bastante nos primeiros meses, relevando o meu francês capenga. Muito obrigada.

Fundamental neste percurso foram os amigos que perto ou distante sempre me apoiaram na realização da dissertação:

Márcio Toledo doce, diplomático e integro, especial em tudo, amigo sempre.

Tatiane M. P. de Godoy sem ela a produção desta dissertação seria impossível. Ela esteve presente em todos os momentos deste percurso, sempre contribuindo imensamente para minhas reflexões, para o debate e orientações que necessitava.

Sandra Pereira, Patrícia Martinelli e Kleber Valadares sempre me deram apoio e força, principalmente, nos momentos que parecia que eu iria esmorecer.

Carlos Henrique Costa Da Silva nossas conversas e confrontos, os diferentes modos de pensar e ver a vida contribuiram muito para minha reflexão.

Cristiano Cardoso por seu carinho, por me escutar e me compreender.

Paulo Estevão, Suzana Hebling e Rafaela Localli pelas inesquecíveis baladas, sem 
elas eu não aguentaria.

Todo o percurso, todo o trabalho seria impossível de ser realizado sem o amor, carinho e compreensão de minha família:

Jayme e Cidinha, pais queridos, amigos e exemplo de força e caráter. Razão de viver.

Vó Marina, impossibilitada de aprender ler e escrever sempre nos apoiou em tudo, para conquistarmos aquilo que ela não pôde...

Tia Nice e Tio Wado, tios-pais, sempre presentes nos diversos percursos da vida. Obrigada por tudo e pelos almoços diários.

Flávia e Guilherme irmãos e amigos companheiros em tudo e todas as horas, exemplos de garra, competência e singeleza. Ao Luciano e a Tati por cuidarem tão bem deles...

Ao meu querido Djamel Sandid que entrou em minha vida depois de iniciado este percurso e tornou-se essencial para sua produção e conclusão. Obrigada pelo constante apoio e me desculpe pelo mau-humor e nervosismo ao final. 


\section{SUMÁRIO}

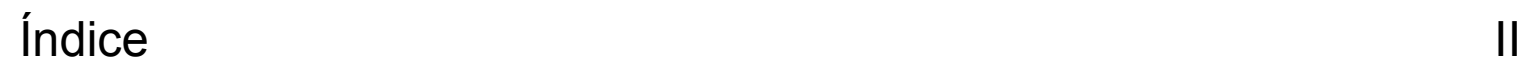

Índice das Tabelas e Quadros III

Índice de Mapas e Figuras III

Resumo IV

Abstract $\quad$ V

Introdução 1

Capítulo 1

Capítulo $2+38$

Capítulo $3 \quad 111$

$\begin{array}{ll}\text { Considerações Finais } & 131\end{array}$

$\begin{array}{ll}\text { Bibliografia } & 136\end{array}$ 
Índice

$\begin{array}{ll}\text { Introdução } & 1\end{array}$

Capítulo 1 - Produção do Espaço Urbano de Rio Claro/SP 13

Cidade e Territorialidade 13

Produção Espacial da Cidade de Rio Claro $\quad 16$

O Contexto Político 24

Capítulo 2 - Práticas Participativas na Gestão da Cidade: o orçamento participativo em Rio Claro $\quad 38$

Contexto Espacial das Regiões do Orçamento Participativo 41

Debate sobre as Divisões Territoriais no OP 51

Funcionamento do Orçamento Participativo em Rio Claro 55

Perfil dos Participantes das Reuniões do OP 60

$\begin{array}{ll}\text { Prioridades } & 70\end{array}$

Orçamento Participativo e Planejamento 95

Orçamento Municipal $\quad 97$

A Normatização dos Processos de Participação Popular 101

Capítulo 3 - Gestão Participativa e Cidadania 111

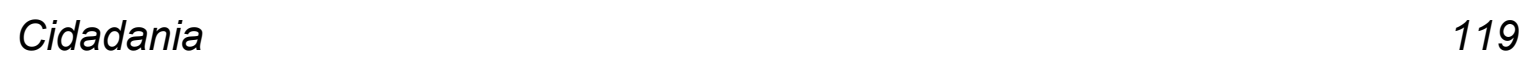

$\begin{array}{ll}\text { Educação e Cultura Política } & 126\end{array}$

$\begin{array}{ll}\text { Considerações Finais } & 131\end{array}$

$\begin{array}{ll}\text { Bibliografia } & 136\end{array}$

Glossário dos Partidos Políticos 139 


\section{Tabelas e Quadros}

Tabela 1 - Faixa Etária dos participantes das Reuniões Regionais do OP 2004

Tabela 2 - Distribuição por sexo dos participantes das Reuniões Regionais do OP 2004

Tabela 3 - Escolaridade dos participantes das Reuniões Regionais do OP 2004

Tabela 4 - Participação em reuniões anteriores do OP

Tabela 5 - Participação em entidades, associações, etc.

Tabela 6 - Entidades ou associações que a população participa

Tabela 7 - Número de reivindicações X Valor Destinado

Quadro 1 - Prioridades Discutidas nas Reuniões do Orçamento Participativo 2004

Quadro 2 - Destinação Final da Verba do Orçamento Participativo 2004

\section{Mapas e Figuras}

Mapa 1 - Divisão Regional do Orçamento Participativo - Rio Claro/SP 40

Mapa 2 - Expansão Urbana da Cidade de Rio Claro/SP - 1893-1981

Mapa 3 - Rendimentos da População Residente em Rio Claro em 2000 segundo Censo IBGE

Foto

Gráfico 1 - Gastos da Prefeitura de Rio Claro/2004

Organograma do Funcionamento do Processo do Orçamento Participativo - Rio Claro/SP 


\section{RESUMO}

Esta dissertação analisa o espaço da participação popular através do processo intitulado orçamento participativo. $O$ estudo da realidade do município de Rio Claro/SP através da discussão e deliberação por parte da população, proposta pela administração municipal, durante sete anos de execução, revelou uma cidade produzida socialmente, porém apropriada de forma desigual e cujas carências urbanas evidenciam a reprodução do processo de produção capitalista. Apresentamos ainda como o processo de produção desigual do espaço urbano se evidencia nas reivindicações feitas pela população quando ela passa a discutir sobre parte dos investimentos do município por meio do orçamento participativo. Debatemos também como a gestão participativa da cidade aponta para o debate da cidadania e os limites deste instrumento de gestão pública.

\section{Palavras-chave}

Espaço Urbano - Orçamento Participativo - Cidadania - Desigualdade Sócioespacial - Gestão Pública 


\begin{abstract}
This dissertation analyzes the space of the popular participation through a process named Participative Budget. The study of the town of Rio Claro/SP reality through the discussion and the deliberation from the population, proposal by the municipal administration, during seven years of execution, revealed a city socially produced, however unequally appropriated and which urban lacks show the capitalism reproduction process.

We present as well how the process of unequal production of urban space highlighted by claims made by the population when they discuss on part of investments of the city by means of the participative budget. We also discuss how the participative management of the city emphasizes the discuss of the citizenship and the limits of this of public management instrument.
\end{abstract}

\title{
Key-words
}

Urban Space - Participative Budget - Citizenship - Social-space Inequalities - Public Management 
A dissertação de mestrado que apresentamos neste momento é produto das reflexões sobre o orçamento participativo e a produção e reprodução do espaço urbano. Tivemos como objeto de estudo a realidade local do município de Rio Claro/SP. A pesquisa foi realizada com acompanhamento direto do processo de organização e realização, do qual integrávamos a equipe de trabalho. O acompanhamento da prática diária de uma secretaria de planejamento aliado à pesquisa teórica possibilitou a observação e análise crítica de todas as etapas do Orçamento Participativo de Rio Claro/SP.

$\mathrm{Na}$ grande maioria dos municípios brasileiros é a democracia representativa a única prática democrática reconhecida pela população como forma de exercer seus direitos civis e que tem seu principal momento nas eleições. No entanto, o que vivenciamos hoje como representatividade política é o distanciamento dos partidos políticos com suas ideologias fundadoras, o "afastamento" dos eleitos com seus eleitores e com suas plataformas de governo, que são amplamente difundidas durante as campanhas eleitorais. Um distanciamento entre eleitores e eleitos que cria a sensação de desorientação dos cidadãos. Por outro lado, percebemos que há uma ausência de participação, produto desta democracia representativa que absolutiza a representação e desloca o poder do representado ao representante pelo ato da eleição, criando um distanciamento - que é inerente ao sistema representativo. Não existe, para a maior parte da população, uma prática democrática cotidiana.

O quadro atual da democracia representativa, em nosso país, confirma sua insuficiência e impossibilidade de representar corretamente grande parte da população, que insatisfeita com a situação colocada, busca a efetivação de seus direitos de cidadãos agindo em seu lugar, manifestando-se contra o que é dado. Porém, ainda é uma parcela reduzida da população que se posiciona e questiona ativamente as irregularidades e a não-presentatividade praticada pelos partidos políticos e governantes do país.

Com a constatação, de uma crise econômica, fiscal e política do Estado na década de 1980, quando ocorre um esgotamento do modelo de intervenção 
desenvolvimentista e centralizador, o Brasil passa a traçar novos caminhos. O país começa a caminhar em direção ao neoliberalismo, caracterizado pela descentralização, através da redução do papel do Estado, marcando o momento de uma nova articulação com a iniciativa privada.

De outro lado, com a descentralização do Governo Federal, o governo local torna-se a instância de reinvindicação da população, pois se trata da instância que está de modo mais claro ligado aos problemas que surgem na vida cotidiana - no plano do vivido. A cidade passa a ganhar destaque e sua produção revela a situação do país e do mundo.

E a reprodução da cidade amplia a mancha urbana, distanciando lugar de moradia e o lugar de trabalho, criando a necessidade de ampliação do sistema de transportes. O crescimento da cidade traz para as Prefeituras Municipais a necessidade de implantação de novos investimentos em infraestrutura (água, esgoto, iluminação), casas populares, segurança, saúde, educação e lazer. Essa gama de obras e serviços necessários à reprodução da vida na cidade é requerida por ampla parcela da população, que quer ter no seu local de moradia as condições mínimas necessárias para a reprodução da vida. Nos bairros centrais, geralmente os mais ricos das cidades, toda essa infra-estrutura e serviços já estão implantados. Nos bairros periféricos, mais carentes, a população reinvidica o que é essencial para a sua reprodução. Para que haja diminuição da desigualdade entre os diferentes locais de moradia e para que todos tenham igualdade de direitos, é necessário que toda a cidade seja provida da infra-estrutura e serviços necessários para a reprodução da vida, sendo estes entendidos como dever do poder público. As obras e instituições públicas devem servir a todos os indivíduos. O acesso à educação, moradia, lazer e saúde aparecem, para a população, hoje, como conquistas pessoais dadas pelo poder aquisitivo que alguns indivíduos detêm e não como direitos sociais. Mas porque há essa diferenciação entre os lugares de uma mesma cidade? Essa diferenciação que revela a fragmentação da cidade, a segmentação da sociedade, existe pela maneira como o espaço urbano foi utilizado pelo poder público e especuladores imobiliários, que utilizam o solo urbano como principal ferramenta para a dominação e a reprodução do modo de produção capitalista. 
Nas cidades se impõe, através da reprodução do capital, uma lógica que aparece como 'ordem estabelecida', que define o modo como a cidade vai se reproduzir. Essa lógica é realizada através da ação dos promotores imobiliários, das estratégias financeiras e da gestão política, algumas vezes de maneira conflitante, algumas vezes de maneira convergente. Essa lógica orienta e reorganiza o processo de reprodução espacial por meio da realização da divisão sócio-espacial do trabalho, da hierarquização dos lugares e da fragmentação dos espaços vendidos e comprados no mercado. A ação do Estado, por intermédio do poder local e através de leis, normativas econômicas, entre outras ações, intervém no processo de produção da cidade e reforça a hierarquia de lugares, criando novas centralidades e expulsando para a periferia os antigos habitantes, criando um espaço de dominação.

A participação popular não rompe com essa lógica, pois ela não interfere nas relações estabelecidas entre promotores imobiliários, sistemas financeiros e gestão política. Essa relação tríade é mantida e não se rompe. A participação popular vai interferir no sentido de amenizar as diferenciações de oferta de serviços e de infra-estrutura entre os lugares da cidade. Mesmo com as atuais discussões públicas e participativas dos planos diretores, a população ainda não tem apreensão sobre a negociação e o jogo de interesses entre essas três esferas, ela somente reivindica o que Ihe é necessário para a reprodução da vida naquele instante específico, não tem uma noção de cidade e da apropriação da cidade como um todo, um pensamento para o futuro da cidade e da vida na cidade. Com isso, as prefeituras enfrentam grandes dificuldades para discutir planos na cidade, à longo prazo, mas também garante uma hegemonia nas decisões.

É nesse contexto que, em alguns municípios brasileiros, se redefinem as relações entre sociedade civil e Estado, com uma maior aproximação entre governante e governado. A participação popular ganha forma e mais adeptos, nunca nos esquecendo que esta participação é sempre comandada pelo poder público, por quem está formalmente no poder, pois não existe entre a população movimentos sociais que reivindiquem esta participação. Porém, para que ocorra a solidificação da prática da participação política e a construção e apropriação de novos espaços de poder, é preciso que a participação direta do cidadão se efetive, é preciso que a cultura política presente em nossa 
sociedade se transforme e que a população "tome para si" o espaço que está se abrindo em algumas prefeituras municipais.

A reconstrução da cultura política é um processo que não gera resultados em pouco tempo. É uma atividade que ocorre como exigência prática, pois num país como o Brasil, que foi governado por uma ditadura militar altamente repressiva e onde, os direitos políticos foram durante muitos anos negado à população, por formas diretas, como a prisão e morte de inúmeros cidadãos que não concordavam com o que era deliberado pelos representantes políticos e, também de maneira indireta através das alterações e manipulações feitas no currículo escolar, por exemplo, com a instauração de disciplinas escolares como a Educação Moral e Cívica. A população em sua grande maioria não tem a prática participativa política como uma das suas formas de expressão e a apropriação dos atuais processos de participação popular, propostos pelo poder público hoje, não é alcançada.

No entanto, surge no Brasil, no final da década de 1980, o orçamento participativo $^{1}$ em Porto Alegre/RS, onde se desenvolveu enormemente após a implantação e aperfeiçoamento do processo em 3 mandatos do Partido dos Trabalhadores e, hoje, com sua continuidade pelo governo do Partido Popular Socialista.

O processo do orçamento participativo em Porto Alegre/RS se inicia em 1989, na gestão do prefeito petista Olívio Dutra, mas se aprofunda e ganha notoriedade maior a partir de 1993, com o governo do prefeito Tarso Genro, que cria uma série de mecanismos de participação e planejamento popular na cidade. Em 1996, com Raul Pont como prefeito, o PT alcança seu terceiro mandato municipal e consolida o orçamento participativo como principal instrumento de governo da cidade e como um "paradigma", segundo Genro (1997 p.45), "para a esquerda e as forças democráticas nacionais e internacionais". Hoje, o PT não está mais no poder municipal de Porto Alegre/RS, pois nas eleições de 2004 o partido não elegeu seu candidato a prefeito e a Prefeitura Municipal de Porto Alegre foi assumida por José Fogaça, do PPS, que em seu programa de governo assegurava para a população a

\footnotetext{
${ }^{1}$ A sigla OP será utilizada nesta dissertação para abreviação de Orçamento Participativo.
} 
continuidade do processo do orçamento participativo, que embora se apresente com uma nova roupagem, mantém a marca de governo popular e participativo.

A idéia do processo do orçamento participativo não nasce descontextualizada de um quadro, pelo qual nosso país estava passando. Diversos fatores favoreceram a implantação e o sucesso do OP em Porto Alegre/RS. Para Souza (2001) pode-se determinar 3 fatores principais que auxiliaram a implantação e permanência do processo, que são:

- Existência de experiências semelhantes antes da redemocratização brasileira. Neste item a autora se refere, principalmente, as experiências de Lages/SC e Piracicaba/SP, que ainda no período da ditadura militar, durante os governos municipais de 1977 a 1982, onde os então prefeitos do MDB iniciaram experiências embrionárias de participação popular, mas com uma ação ligada a administração municipal, visto que, a mobilização e formação dos grupos organizados da população era realizado pela prefeitura. Ainda sobre iniciativas de participação popular anteriores ao OP de Porto Alegre/RS, encontramos as experiências descritas por Costa (1997) sobre os municípios mineiros de Governador Valadares, Uberlândia e Juiz de Fora, onde prefeitos do PMDB incentivaram a formação de associações de moradores nos bairros das cidades, para que esses se tornassem os principais elos de ligação entre administração municipal e população.

- Aumento dos recursos municipais após a abertura política e a Constituição de 1988 e reforma fiscal implantada por alguns municípios, o que aumentou a capacidade de arrecadamento dessas instituições municipais, e permitem maiores investimentos nas cidades por parte das prefeituras municipais.

- Aumento da presença de partidos considerados de esquerda nos governos locais, principalmente do PT. Segundo Souza (2001) houve um grande aumento de prefeituras comandadas pelo PT. O Partido dos Trabalhadores, que em 1988 administrava 32 prefeituras municipais passou para 53 em 1992; 115 em 1996 e alcançou em 2000, 187 prefeituras municipais. Já nas eleições de 2004 o número de prefeituras brasileiras governadas pelo PT subiu 120\%, em relação a 2000 , e alcançou o número de 411 prefeitos eleitos. Como a principal bandeira 
do partido é governar junto com a população, através da participação popular, isso beneficiou a implantação do OP em diversos municípios brasileiros, que se tornou compromisso eleitoral dos candidatos e uma das principais marcas positivas do partido.

Um outro fator, que não foi apontado por Costa (1997), mas que nos parece determinante para a implantação de processos de participação popular tem ligação com o fim da ditadura militar, que durante anos impediu a livre manifestação e reivindicação popular em nosso país, trazendo com isso um quadro de distanciamento da população, de maneira geral, com a vida pública e política. Os partidos de esquerda, que em sua origem carregam uma característica fortemente popular e da maioria excluída, têm como um dos seus principais objetivos trazerem de volta e fortalecer os movimentos sociais, as expressões populares, que até então eram perseguidos. Esses partidos e, em especial o PT - que foi criado com base nos movimentos sindicais e sociais - , tem a intenção de fazer renascer e/ou criar movimentos populares reivindicatórios.

O orçamento participativo aparece como uma das ações capazes de restituir a participação da população na construção das políticas que visam às transformações na cidade. Mas não é a única. Concomitantemente, é preciso que se exerçam diversas outras formas de gestão participativa, pois não é somente de orçamento que se compõe às atividades do município. A participação popular na gestão de cidades apresenta-se de diversas formas, em diversos municípios brasileiros. Como exemplo, podemos citar os diversos conselhos temáticos que se ampliam pelas cidades brasileiras, os congressos da cidade, que discutem questões para o futuro da cidade ao longo prazo e os conselhos gestores, que atuam na gestão de escolas e unidades de saúde. Dentre os vários processos de participação popular encontrados, nessa pesquisa, nos dedicaremos ao do orçamento participativo, pois através dele encontramos a destinação de investimentos da cidade nas mais diferentes áreas e regiões dos municípios.

O orçamento participativo se apresenta como uma forma de articulação entre a burocratização encontrada nas administrações municipais e os anseios da população na cidade e vai desenvolvendo-se e adaptando-se de maneira dinâmica, revelando transformações pelas quais a cidade vem passando, a 
partir da participação da sociedade local. As prioridades colocadas pela população revelam necessidades que surgem, no plano da vida cotidiana, devido à "explosão da cidade" gerando a crescente periferização e aprofundando o processo de segregação.

A idéia orientadora do orçamento participativo, difundida pelos governantes dos diversos municípios que contam com esse processo no seu programa de gestão e defendida por seus criadores é a da transparência da gestão municipal, o fim do clientelismo, da corrupção e da demagogia através do estímulo capaz de reunir os interessados na identificação dos problemas que precisam ser resolvidos, estabelecer hierarquias nos investimentos e nas prioridades mais urgentes, analisar os recursos que a prefeitura tem em disponibilidade, buscar medidas fiscais para aumentar a arrecadação municipal e redistribuir a riqueza. Isso não garante que todas as experiências implementadas trabalhem e efetivem essas mesmas idéias, já que o OP é proposto e gerido pelos poderes públicos municipais que possuem interesses e ideologias diversos.

Para Genro (1997 p. 23) a essência do OP é a de:

... democratizar as decisões de uma nova gestão, a partir de Conselhos Populares... permitir que cada cidadão pudesse interferir na criação das políticas públicas e nas demais decisões de governo que tivessem importância para o futuro da cidade.

Para se lograr esses objetivos seria necessário, segundo o autor, realizar uma espécie de transferência de poder para a população para se alcançar gradativamente a substituição da representação política pela democracia direta.

O fato é que após 17 anos de implantação e execução do OP em Porto Alegre/RS - experiência mais conhecida e duradoura no Brasil - o processo se aprimorou, chegando a alcançar complexidade e nível burocrático elevado por se tratar de uma forma de gestão popular, o que nos parece que complica o entendimento da população que participa do processo, porém sem até o momento ter alcançado a superação da representação, como imaginado por seus idealizadores.

A execução de processos de participação popular, e em especial o OP, traz à população e às administrações municipais um novo modelo de gestão 
das cidades, que inclui um processo educativo daqueles que participam do processo (prefeitos, vereadores, população); um avanço para o exercício da democracia, visto que, a população se aproxima da estrutura de funcionamento da administração pública, mantém um maior contato com seus representantes e consegue melhor avaliar e participar do desempenho de um governo que ela, durante as eleições, escolheu. Ações como essas combinam democracia representativa com participação, mudam a vida política das pessoas que se dispõem a participar do processo, trazem uma nova forma de relacionamento entre poder público local e a sociedade como um todo, sem, no entanto, substituir a representação.

O OP também vai revelar a fragmentação do espaço urbano através das reivindicações feitas pela população. As reivindicações por infra-estrutura básica revelam os fragmentos do espaço que têm e os que não têm essa infraestrutura. Revela a segregação da população. Segregação que é a negação do urbano e da vida urbana, pois não permite a apropriação e o uso do espaço urbano.

Isso evidencia a necessidade da análise dos resultados que estão sendo obtidos com a participação da população na gestão dos municípios, identificando se estão sendo notadas diferenças no planejamento e organização das cidades e os resultados disso na produção e na reprodução do espaço. Estas são questões bastante pertinentes, visto que, inúmeras cidades do Brasil, estão adotando essa prática para a formulação do orçamento municipal e há a possibilidade de uma mudança no planejamento urbano, que conta agora, com a participação dos moradores dos distintos lugares do município.

Consideramos que é necessário identificar se realmente há uma maior distribuição de recursos financeiros para as periferias, em detrimento, da concentração de obras e serviços nas áreas centrais e bairros mais abastados da cidade, e a inclusão, participação e conscientização da população na construção da democracia.

Por outro lado é preciso identificar e entender qual conceito de cidade está presente, tanto por parte do Estado, como da sociedade civil, embasando a participação dos interessados e como se confrontam os interesses do 
Estado, da sociedade local e da iniciativa privada - através de um "jogo de forças" que se realiza no plano do político, mas que aponta o processo de reprodução da cidade e da vida na cidade. Esse é o encaminhamento de nosso trabalho, que será analisado através do modo como o orçamento participativo, enquanto elemento da gestão se realiza revelando as contradições na cidade.

É importante que se tenha a real noção das mudanças e transformações que essas práticas trazem aos municípios, porque entendemos que o espaço enquanto produto e condição de reprodução das relações sociais pode conter novas possibilidades que permitam mudanças na vida cotidiana.

Pretendemos também identificar e analisar críticamente nesta dissertação as transformações e configurações que, especificamente, a prática do orçamento participativo trouxe para o município de Rio Claro/SP, em relação ao que se apresentava anteriormente, ou seja, as decisões sobre os investimentos na cidade que se concentravam, totalmente, nas mãos do prefeito e seus assessores. Esta prática é bastante nova e pouco analisada, em relação aos resultados apresentados no espaço urbano.

Analisaremos o papel que o orçamento participativo trouxe para a prática espacial do município de Rio Claro. A escolha do município de Rio Claro/SP, para área de pesquisa, se refere ao período e regularidade na prática do Orçamento Participativo. No período 1998 a 2004 o município contou com a execução do processo do orçamento participativo e no decorrer desse período o processo passou por algumas modificações, apresentando-se como a possibilidade de um exercício de cidadania e também como uma concretização da prática participativa. Esta continuidade do processo permitirá que se analisem os resultados apresentados e as dificuldades enfrentadas.

O governo progressista em questão se deu durante os anos de 1997 a 2004 e teve como uma das principais características a implantação de processos de participação popular na administração municipal, processos esses que incluem a realização de duas grandes conferências municipais, que reuniram mais de 4.000 pessoas (por volta de $2 \%$ da população do município) e que teve como principal objetivo discutir o futuro da cidade de Rio Claro, juntamente com sua população. Inclui também a criação de 21 conselhos municipais temáticos que trabalham com diversas questões ligadas ao 
interesse de toda a população, entre eles podemos citar os conselhos de educação, saúde, segurança, consciência negra, e o conselho que analisaremos neste trabalho, que é o do Orçamento Participativo.

O município de Rio Claro, que após 8 anos administrado por este governo, cuja coligação perde as eleições em 2004 para um partido com orientações de extrema direita, volta a ter um governante que já havia sido prefeito, deste mesmo município, sendo que parte do mandato foi cumprido dentro da prisão. E este governante após assumir a prefeitura abandonou totalmente as práticas participativas implantadas anteriormente, e deixou de realizar as obras previstas pelo orçamento participativo no ano de 2004.

O desvendamento do processo de constituição do Orçamento Participativo em Rio Claro/SP nos leva a questionar se ele estaria revelando a possibilidade de concretização de mudanças na vida urbana e em que direção. Questionamos também qual é a direção desejada pela população. Na medida em que o OP gera uma política de intervenção no espaço, qual é a potência dessas transformações ou se essas transformações permitem uma mudança na produção do espaço?

Esta dissertação apresenta as nossas constatações e reflexões sobre a prática do OP e dá continuidade aos estudos iniciados ainda no Trabalho de Graduação realizado na conclusão do Curso de Geografia, na Universidade Estadual Paulista, Campus Rio Claro/SP, onde realizamos um estágio, junto ao Departamento de Desenvolvimento Urbano e Gestão Territorial, que foi o setor responsável pela organização e desenvolvimento do Orçamento Participativo. Durante esse período pudemos estabelecer maior proximidade com 0 processo, que nos foi apresentado como uma maneira inovadora de desenvolver a gestão municipal com a participação da população local.

Após a realização do Trabalho de Graduação continuamos a trabalhar junto ao departamento de organização do OP onde acompanhamos durante mais 2 anos o funcionamento deste processo. Esse contato constante com o OP nos trouxe uma visão bastante vantajosa, pois pudemos estabelecer relações com as pessoas que participam do OP e do Conselho do Orçamento Participativo, observamos os avanços, desafios que esse processo produz e tivemos um contato maior com a realidade administrativa do município. 
A participação em projetos de cooperação internacional nos proporcionou também um contato com experiências diversas de participação popular. Pudemos conhecer a realidade de Leon (segunda maior cidade da Nicarágua) e onde a população, ao contrário do ocorrido em Rio Claro/SP, exige a oportunidade de participação sem que este convite parta da administração municipal. Os habitantes de Leon vivem cotidianamente a prática participativa, que está incorporada em sua maneira de viver. Lá não há possibilidade que os processos democráticos se percam ou mudem com a troca de governo, pois a participação está contida na prática cotidiana dessas pessoas. Conhecemos também a realidade participativa de Issy-les-Moulineaux (pequena cidade da região de Paris, na França) onde a população de alto poder aquisitivo, trabalha todo o dia e tem seus afazeres noturnos fazendo com que as as reuniões presenciais não surtissem efeito, e por essa razão a prática participativa teve que ser adaptada a essa realidade. Atualmente, com a participação eletrônica, os habitantes de Issy-les-Moulineaux podem opinar através do uso da internet e também participar das sessões da Câmara Municipal através da televisão e com perguntas telefônicas.

- A dissertação que ora apresentamos está dividida em três capítulos assim distribuídos: Capítulo 1: Produção do Espaço Urbano de Rio Claro/SP. Nele tratamos da questão da produção do espaço urbano, especificamente na cidade de Rio Claro. Também abordamos o processo de formação da cidade e sua territorialidade.

- Capítulo 2: Práticas Participativas na Gestão da Cidade: o orçamento participativo em Rio Claro/SP. Neste capítulo encontramos as especificidades da produção deste espaço urbano, através da análise dos mapas de Expansão Urbana de Rio Claro e dos Rendimentos da População da Cidade em 2000, baseado nos dados do IBGE. Trazemos o debate sobre a divisão territorial que é realizada no processo do OP, juntamente com a descrição do funcionamento do processo em Rio Claro. Analisamos também o perfil dos participantes do OP, em 2004, através de um questionário aplicado à 610 moradores. Ainda neste capítulo fazemos uma análise espacial com referência às prioridades discutidas nas reuniões regionais do OP, onde podemos visualizar de 
maneira mais concreta as desigualdades espaciais e a carência pela qual a cidade vive.

- Capítulo 3: Gestão Participativa e Cidadania. Debatemos, neste capítulo, a cidadania, suas diferentes concepções e o que ela revela ao processo de produção social do espaço. Apresentamos também a necessidade de mudança da cultura e educação política para que possa existir um avanço nas questões políticas da sociedade e como elas podem contribuir para a gestão da cidade.

- Em nossas considerações finais pautamos as motivações comuns para implantação de processos participativos e as expectativas e interesses diversos que os sustentam, discutindo os interesses de organismos internacionais na promoção destes processos, que afirmam a permanência do processo de produção capitalista. Apresentamos os desafios da conquista e efetivação da cidadania e democracia dentro do sistema capitalista. Finalmente tecemos algumas considerações sobre o período de execução do orçamento participativo em Rio Claro e sua não continuidade. 


\section{Capítulo 1 - Produção do Espaço Urbano de Rio Claro/SP}

\section{Cidade e Territorialidade}

O espaço é produto das realizações humanas, que ao produzir sua existência, sua sobrevivência (re) produz também o espaço urbano. Dinâmico e em constante (re) produção, o espaço contém elementos históricos, porque é produzido constantemente e historicamente. Porém, o espaço não é apenas produto das realizações da sociedade é também condição e meio para esta, pois o espaço que está dado hoje vai comportar a produção do espaço do amanhã.

A análise geográfica permite desvendar os processos que constituem a produção do espaço social. Portanto, cabe ao geógrafo analisar os processos de produção espacial levando em consideração as relações sociais que o produzem, juntamente com o processo histórico que o acompanha sem interrupção, para assim, compreender o espaço de hoje e suas possibilidades.

A cidade é resultado da materialização do processo histórico e social de produção do espaço geográfico. A cada momento histórico se produz um espaço, revelando sempre, uma cidade e suas possibilidades. "A reprodução do espaço urbano é um fenômeno contínuo, em movimento, o que significa que a cidade vai se transformando à medida que a sociedade se metamorfoseia." Carlos (1997 p. 22).

O espaço urbano e a cidade são produzidos sob a égide do modo de produção capitalista, que tem na propriedade privada da terra o seu modo de apropriação. Temos a produção social do espaço e sua apropriação privada, o que gera conflitos e desigualdades. Nessa lógica o valor de uso da cidade se encontra em detrimento do valor de troca contido na ação que transformou o espaço urbano em mercadoria. $O$ processo de reprodução espacial revela a contradição entre o processo de produção social do espaço, pois são as relações sociais que produzem este espaço e sua apropriação se dá de maneira privada, resultado do processo de acumulação de capital.

$\mathrm{Em}$ fato, o processo de reprodução revela outras contradições. A contradição entre estratégias do Estado que, muitas vezes, aliado aos promotores imobiliários e as estratégias financeiras visam à reprodução do capital e a dominação do espaço, que está em conflito com a reprodução da 
vida, que visa o uso do espaço e sua apropriação não como mercadoria, mas sim como base material para a vida.

Então, sabemos que o espaço hoje é produto da sucessão de momentos históricos que constante e dinamicamente o transformam e que também deixam a marca do seu tempo. Na paisagem urbana podemos identificar testemunhos dessa sucessão de períodos históricos no qual o espaço se metamorfoseia. Mas a metamorfose do espaço não acontece somente pela sucessão de tempos, ele também é transformado através da ação da sociedade que se reproduz neste espaço, ao mesmo tempo que o produz. "O espaço aparece enquanto condição, meio e produto da reprodução social." (CARLOS, In: Revista Cidades, 2005 p. 227.)

Observamos a reprodução das relações sociais ao mesmo tempo reproduz a cidade, que é realidade material carregada de realidades sociais distintas.

Para a análise da cidade Carlos (2005), nos alerta para a importância da consideração de três dimensões espaço-temporais.

"Primeiro, em sua dimensão histórica, a cidade é obra da civilização e nessa condição, produto realizado ao longo de uma série de gerações (portanto trabalho materializado) e, nesse plano, aparece como acumulação de tempos. Em segundo lugar, enquanto prática social, a cidade é espaço tempo da ação que funda a vida humana em sua objetividade (não limitada a um simples campo de experiência segunda a definição de Augustin Berque). Nessa condição, a cidade é, por excelência, o lugar da apropriação da vida, através do corpo e de todos os sentidos, que para Lefebvre são as determinações do ser humano. Finalmente, devemos pensá-la como virtualidade, possibilidade futura de realização da vida nesse plano, ela aponta a universalidade do humano." (CARLOS, In: Revista Cidades, 2005, p. 225).

Hoje, a produção espacial da cidade nos revela em sua paisagem e na vida cotidiana, a apropriação desigual, produto da desigualdade social. espaço urbano é o lugar da apropriação da vida, porém deixada para segundo plano, para se tornar apropriação privada, mercadoria.

Definida por Roncayolo (1990, p.29):

"A noção de cidade implica a aglomeração de uma população. Concentra lugar de morar e atividades, porém atividades que se distinguem da exploração direta do solo, são atividades especializadas e contribuem também para as trocas e relações da sociedade; um modo de vida; uma organização 
dos espaços e objetos urbanos que implicam um arranjo coletivo."

E a especificidade da cidade se mostra em duas direções:

- A cidade não pode ser entendida unicamente no interior de seus limites. Ela não acontece isoladamente. Ela tem relação com o espaço ao seu redor, com outras cidades e espaços distantes.

- Ela também não se reduz aos objetos urbanos ou a uma combinação de funções. Ela reune uma população caracterizada por uma composição demográfica, social e étnica. Ela define uma forma de comunidade ou coletividade, então é essencialmente política no seu princípio.

O espaço urbano e a cidade não podem ser vistos como resultado material produzido através do tempo sem interligação com seu entorno. Não é apenas palco de intervenções urbanísticas realizadas por agentes públicos que visam benefício de um pequeno grupo, reproduzindo o modo de produção capitalista. A cidade é um produto coletivo, com características específicas, construídas através do tempo e que revela a acumulação de períodos históricos. É resultado da vida que nela acontece, da apropriação dos lugares, da identidade criada por seus cidadãos e da possibilidade futura, virtualidade.

Não se pode analisar a cidade como um ator social autonômo, fora do tempo e da sociedade. Uma fotografia da vida que acontece na cidade e o lugar que ela se localiza não explica por eles mesmos a sociedade e suas atitudes.

A cidade vai revelar elementos que a formam e que dão sentido a sua materialidade. Ela tem uma territorialidade. Territorialidade esta que tem origem social. Definida por Soja (apud Roncayolo, 1988, p. 182), como:

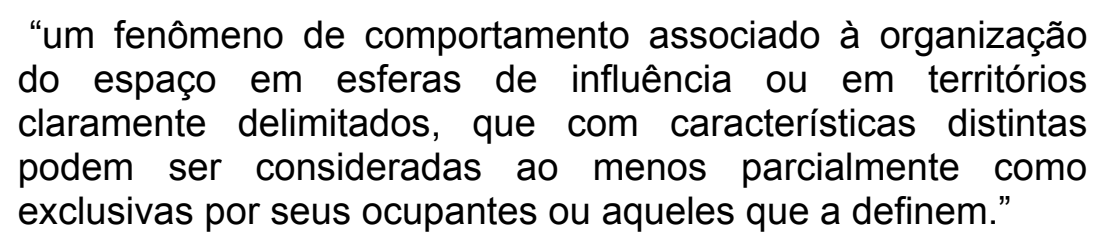

A territorialidade construída socialmente tem estreita relação com a identidade, que vem da cultura mais do que da localização física. A identidade vem do sentimento de pertencimento, da apropriação que ela pode propiciar. A apropriação e a aproximação produto da territorialidade "é uma combinação de 
consciência de pertencer a uma comunidade e sentido da territorialidade" Roncayolo (1990, p. 60).

A vizinhança espacial não é suficiente para aproximar os indivíduos e anular as distâncias sociais, mas ao contrário, pode levar ao confronto de experiências, expectativas e sensibilidades opostas. Numa mesma cidade encontramos territorialidades diferenciadas, apropriações distintas e que juntas dão características à cidade.

As desigualdades espaciais e sociais encontradas na cidade são resultado da reprodução e acumulação do capital realizado pelos especuladores urbanos e auxiliados pelo Estado, que colabora com essa reprodução. A apropriação privada do solo urbano vai expulsar os trabalhadores, que não acompanham a evolução do valor do solo urbano, principalmente, no centro. Estes trabalhadores são expulsos para as periferias, onde o valor do morar é mais acessível. Mas esta expulsão rompe com a identidade, com o sentimento de pertencimento, que se tinha com a cidade. Os trabalhadores são expropriados da vida urbana. A cidade passa a ser local de moradia e trabalho e as relações de vizinhança e territorialidade se perdem.

\section{Produção Espacial da Cidade de Rio Claro}

Cabe nesse momento construirmos um conhecimento sobre a cidade de Rio Claro. Construir o entendimento do que é a cidade hoje e como se deu sua produção espacial.

Rio Claro é uma cidade que se produziu de forma desigual, fruto da apropriação privada da terra, causada pelo modo de produção capitalista. Essa desigualdade está evidente na paisagem urbana, que revela os diferentes usos, os diferentes tempos, que deixam sua marca e diferentes formas de ocupação. Percebemos caminhando pela cidade, que existem áreas dotadas de toda sorte de infra-estrutura e serviços urbanos e há também aquelas áreas que vivem a carência diária, convivem com a falta de pavimentação, iluminação e com o mau atendimento da saúde e educação pública.

A cidade de Rio Claro, localizada no interior de São Paulo, nasce em 1827 como pouso de tropas que se direcionavam para o interior do país.

Em meados do século XIX a cidade conhece um período de desenvolvimento por ser ponta de trilho da ferrovia paulista, que se expande no 
estado, graças à necessidade de circulação do café, que era o produto mais importante da economia brasileira.

Já no início do aglomerado urbano, em 1840, estabeleceu-se na cidade um arruamento em tabuleiro de xadrez. Esta forma de organização da cidade era considerada por seus idealizadores e fazendeiros da região como símbolo do progresso, ordem, planejamento, racionalidade e modernização. Esta forma de arruamento se perpetua até os dias de hoje.

A expansão da cidade se dá no eixo norte-sul criando uma espinha dorsal, que orienta o crescimento urbano durante certo período. Essa orientação se dá pelas barreiras físicas encontradas na expansão da cidade: a leste o Horto Florestal e rio Ribeirão Claro e a sudoeste a Rodovia Washington Luís, esta última barreira já transposta em 1967.

Porém a maior expansão urbana e a multiplicação dos bairros da cidade, ocorre no período 1940-1967, intensificando-se ainda mais a partir de 1970 com o aumento do perímetro urbano. Este crescimento da área urbana se dá pela instalação ao norte da cidade, do distrito industrial, que atraiu muitos trabalhadores para essa região.

De 1970 a 1980 intensificam-se os processos de especulação imobiliária, com grande aumento do perímetro urbano, que passa a conter maior número de loteamentos do que se necessita, "houve um número maior de quarteirões vazios do que ocupados." Silva (1994, p.75)

O crescimento da cidade de Rio Claro e o desenvolvimento de sua economia estão totalmente conectados com a evolução cafeeira e industrial, no estado de São Paulo e no Brasil. As relações capitalistas de produção se intensificam no país, logo na cidade, intensificando a produção do espaço urbano.

O rápido crescimento da cidade traz grandes problemas para a vida que nela se desenvolve, visto que, o crescimento populacional era maior do que a oferta de emprego existente. Os migrantes e imigrantes, muitos vindos da zona rural não tinham como morar no centro da cidade ou nos bairros que já possuíam toda infra-estrutura e serviços públicos, pois estes se apresentavam como locais mais caros para se viver. A alternativa encontrada por essa população é viver nas periferias mais distantes, onde os terrenos são mais baratos, ou onde há loteamentos clandestinos. Então, a autoconstrução 
praticada, principalmente, aos finais de semana, em lotes periféricos, muitas vezes irregulares e sem nenhuma infra-estrutura são ocupados e tornando-se a solução possível para estas pessoas.

Outra alternativa de sobrevivência encontrada pela população nessa periferia mais carente é a divisão do lote comprado por dois ou mais compradores, o que garante o pagamento das prestações, já que o valor será dividido. Isto fortalece as irregularidades da propriedade, já que, legalmente, é proibido o desmembramento de lotes.

É na área norte da cidade onde mais se localizam os bairros periféricos e onde concentra em maior número a população de baixos rendimentos. Essa localização acontece devido a instalação do único distrito industrial da cidade, em 1974. Porém as indústrias que ali se instalam não absorvem toda a mãode-obra que vem para próximo deste distrito.

Muitas vezes, quando não encontram trabalho nessa área ou quando vêem seu imóvel valorizado, pela instalação de algumas infra-estruturas, os trabalhadores migram internamente na cidade buscando bairros mais periféricos, casas menores ou de pior qualidade de construção, logo, com menor preço.

A população de baixa renda sem alternativa se encontra cada vez mais na periferia distante, sem serviços sociais e sem infra-estrutura. Aqui, muitas vezes, os movimentos sociais se fortalecem e reivindicam melhorias para o seu bairro; serviços que são essenciais à reprodução da vida. Os melhoramentos em infra-estrutura e serviços sociais, quando instalados, são motivos de grande euforia entre os moradores, porém, rapidamente transformam-se em problema, porque isso significará o aumento de taxas, impostos, contas que extrapolam os rendimentos dessas famílias e essa população novamente se vê expulsa para áreas mais periféricas com menos serviços, menos infra-estrutura, logo, com menor valor da terra e menos contas a pagar.

O que é direito inalienável do cidadão, o direito de morar, é conquistado mediante estas estratégias de sobrevivência do trabalhador, visto que, nas periferias a autoconstrução, a apropriação clandestina e os cortiços se configuram como as formas predominantes do morar da classe de baixa renda.

Outro problema enfrentado pelo crescente distanciamente centroperiferia é a dependência cada vez maior que a população de baixa renda tem 
com os meios de transporte coletivo e também o aumento dos gastos que essa dependência traz para esta população, que já tem seus rendimentos tão reduzidos.

O distanciamento da área central e dos locais de trabalho faz com que essas pessoas de menor poder aquisitivo, que são obrigadas a viver na periferia da cidade, necessitem dos transportes públicos para se locomover. Essa população se torna dependente dos transportes públicos e cada vez mais aumenta a parcela que devem pagar para poder utiliza-los, o que traz um impacto significante em seus rendimentos. O fornecimento deste serviço é precário e o aumento da demanda não é suprido pelo poder público, que em sua política valoriza o transporte individual rodoviário. A demanda por transporte público, principalmente, os ônibus, cresce e o aumento dos veículos disponíveis não acompanha o crescimento. Além da insuficiência de frota para atender a demanda crescente, o tempo gasto no percurso casa-trabalho é um outro agravante da periferização da cidade e da falta de investimentos significantes no transporte ferroviário e metroviário. Isto traz um desgaste físico e mental ao trabalhador e a diminuição do seu tempo livre.

Periferização e imobilidade são fatores que contribuem para o isolamento das pessoas e a fragmentação do espaço. A territorialidade é desfeita, a identidade com o lugar se perde.

Santos (1990) aponta a opção pública feita pelo desenvolvimento rodoviário, em detrimento de outras opções de transporte, como o ferroviário, por exemplo, como um dos principais fatores de aumento da malha urbana tão acelerada que ocorreu, principalmente, nas cidades dos países subdesenvolvidos. Como conseqüência da criação de longas avenidas, verifica-se a formação de cidades espalhadas, ótima para o crescimento da especulação imobiliária. A especulação se dá através da fácil acessibilidade a lugares distantes do centro da cidade, que obrigam a população de baixa renda a se mudar, visto que, nas áreas mais centrais o preço do solo urbano é elevado devido a localização central, a acessibilidade e a provenção de meios de consumo coletivo. Essa população expulsa do centro busca as periferias distantes para viver, principalmente, aquelas que ainda não possuem serviços sociais e de infra-estrutura instalados, pois essa carência de serviços significa preços mais baixos. 
A forma espacial da cidade e a paisagem urbana revelam a contradição na produção do espaço, contradição esta causada pela apropriação privada da terra e pelo modelo de desenvolvimento econômico concentrador. O espaço geográfico é segregado segundo a estrutura de classes sociais e cabe a classe mais carente ocupar as áreas mais degradadas ou despreparadas da cidade.

O que é mais surpreendente quando analisamos essa ocupação do espaço da cidade é quando interligamos os elementos relacionados à questão da renda da terra e especulação imobiliária e seu relacionamento com o poder político. Constatamos que o crescimento urbano e sua orientação têm forte relação com a estrutura de poder no município.

A especulação imobiliária é o fator que garante o aumento da renda da terra urbana para seus proprietários. A especulação é " a antecipação das expectativas da sociedade enquanto a criação de novos valores urbanos, benefício passivo de uma mais valia de origem externa" Roncayolo (1988, p.96)

O mesmo autor analisando os produtores do espaço urbano aponta a existência de três atores principais.

1) Os proprietários do solo urbano e de imóveis, que atuam para a constituição e gestão de seu patrimônio exercendo um poder social.

2) As organizações econômicas, que se dividem naqueles que:

- utilizam o espaço para fins específicos (bancos, comércios, espetáculos) e, por isso, intervém no que Roncayolo chama de "fabricação da cidade";

- e nas companhias ou sociedades imobiliárias, empresas de construção, organismos de financiamento.

3) Os poderes públicos, que acompanham as operações do capital privado.

Em Rio Claro, o que observamos é que os três atores produtores do espaço, apontados por Roncayolo, concentram-se em um só. O que traz maior intensidade na desigualdade da produção do espaço urbano.

As estratégias utilizadas para a prática da especulação imobiliária pelos loteadores são diversas. Há os que consideram e cobram pela expansão da rede de energia elétrica, água e esgotos considerando-os como melhorias do loteamento, sendo que, tais serviços são previstos por lei e são obrigatórios para comercialização de lotes. Há os loteadores que colocam à venda, 
primeiramente, parte da gleba de terra, onde estão localizados os piores lotes e, após, a ocupação destes lotes e o recebimento de toda infra-estrutura partem para a venda de novas áreas da gleba onde se encontram os lotes mais bem localizados e agora com toda a infra-estrutura instalada tendo seu preço muito maior e, conseqüentemente, maior será a renda auferida ao proprietário.

As modalidades de expansão da especulação imobiliária não são privilégio de promotores imobiliários, pois até mesmo, ações do Estado colaboram para o aumento dessa prática. $O$ poder público se demonstra perverso em algumas ações.

O exemplo do Banco Nacional de Habitação (BNH), utilizado por Santos (1990), demonstra uma dessas modalidades. A escolha de locais para implantação de conjuntos habitacionais públicos parecem ter passado por um requisito obrigatório, que era o do distanciamento de centros urbanos. Essa prática deixa espaços vazios em seu caminho e a implantação de conjuntos habitacionais, realizados através de uma política pública, torna obrigatória a instalação de serviços públicos beneficiando, dessa forma, os espaços vazios deixados e seus proprietários. O próprio poder público cria as desigualdades espaciais e beneficia a especulação.

O que é surpreendente é que, ao contrário, do que se pode imaginar nem sempre a maior especulação imobiliária acontece nas localizações destinadas à bairros nobres ou centrais. Lucca (1981) realizou pesquisa junto aos classificados dos jornais locais da cidade de Rio Claro, no período de 1971 a 1981, e constatou que os lotes da periferia tiveram aumento percentual bastante superior quando comparado aos lotes localizados nas áreas centrais e nas áreas destinadas à população de maior poder aquisitivo.

“... observa-se que há uma grande diferença na evolução dos preços dos bairros da classe mais abastada, para a classe mais pobre, indicando que há uma maior especulação com a terra, que serve de moradia para a classe trabalhadora, do que nos loteamentos das classes mais abastadas da população." (LUCCA ,1981 p.23)

Isto mostra que embora os bairros centrais tenham maior valor, não são eles que possuem maior valorização de seu preço, pois percentualmente, os bairros periféricos destinados à instalação da população de baixa renda são os que apresentam valorização mais acentuada no período. 
Nesta mesma pesquisa verificou-se através de dados coletados, junto à Prefeitura Municipal de Rio Claro, que havia uma estreita ligação entre as pessoas que ocupavam cargos administrativos municipais, responsáveis pelas alterações do perímetro urbano e permissão para implantação de novos loteamentos e os agentes imobiliários. Havia, dentro do poder público municipal, manipulação de informações e ações que favorecia determinados proprietários de terras, que tinham de alguma forma ligação com quem ocupava o poder. Os proprietários de determinadas terras, quando chegavam ao poder obtinham rapidamente benefícios para instalação de infra-estrutura em seus lotes; projetos de lei que aumentavam o perímetro urbano para beneficiar suas propriedades e aprovação de loteamentos, muitas vezes, que não estavam dentro das normas exigidas por lei.

Lucca (1981) apresenta alguns exemplos de benefícios concedidos a glebas de terra que tinham estreita ligação com membros do poder público municipal. Entre eles citamos três exemplos:

Entre 1956 e 1959 é aprovado o loteamento Jardim Ipê, de propriedade de João Augusto Hoefling. Neste mesmo período encontravam-se dois membros da família em cargos públicos municipais. Argemiro Hoefling, então vice-prefeito e Paulo Hoefling, vereador municipal.

Em 1967 é aprovada na Câmara Municipal a alteração do perímetro urbano de Rio Claro, através do decreto n¹558/67. É também aprovado o loteamento denominado A. Karam, de propriedade de Alfredo Karam, sendo que, Waldemar Karam era vereador neste período. A área expandida do perímetro urbano, aprovado pelo decreto, abrange este mesmo loteamento, que anteriormente, encontrava-se na zona rural. Já em 1977 é aprovada uma outra parte do loteamento A. Karam, esta nova parte de propriedade do, ainda vereador, Waldemar Karam.

No ano de 1978 foi loteado o bairro da Assistência, que pertencia a Nereu Mamprim e a Demerval da Fonseca Nevoeiro Junior, prefeito municipal na época e é hoje, o atual prefeito de Rio Claro.

O que vemos é que diversas leis municipais aprovadas beneficiaram os capitalistas locais e que, muitas vezes, são os detentores do poder público.

Uma outra irregularidade que verificamos é relacionada a infra-estrutura dos bairros. Os loteamentos direcionados para as classes mais altas recebem 
toda a infra-estrutura existente, enquanto os loteamentos direcionados para a classe trabalhadora não possuem infra-estrutura e quando são implantadas, muitas vezes, são pagas adicionalmente ao valor do lote pelos moradores. A obrigatoriedade do pagamento de taxas referente a benefícios de infraestrutura nos bairros, expulsa os moradores para áreas ainda mais periféricas, já que estes não têm condição de pagar pela implantação dos novos serviços ou veêm a venda de seu imóvel valorizado como alternativa para solucionar problemas financeiros.

A acumulação e concentração de capital, logo, da propriedade da terra traz ao espaço uma configuração desigual, pois sua distribuição e apropriação serão determinadas pelo lugar que o indivíduo ocupa na sociedade capitalista. O espaço se configura em um instrumento político, manipulável e estratégico para a realização e manutenção do poder.

Se tivermos em conta que são as relações sociais que comandam o processo de (re) produção do espaço geográfico e que este espaço é uma produção social e histórica, concreta e dinâmica poderemos compreender de maneira mais clara as transformações que a sociedade e, conjuntamente, o espaço urbano vem sofrendo atualmente.

Sabemos que a sociedade, através das suas relações sociais, produz a vida e ao mesmo tempo o espaço da vida e, que esta produção está ligada ao processo do trabalho e da produção de mercadorias, pois, através das atividades produtivas, se materializa espacialmente e, se fundamenta a luta de classes marcada pela contradição entre a produção espacial social e a apropriação privada realizada, comumente, pelos setores econômicos mais privilegiados.

Os espaços produzidos são marcados pelo estágio de desenvolvimento de forças produtivas sociais e são carregados de desigualdades espaciais e sociais, consequência da apropriação privada da terra. A produção espacial é desigual porque o espaço é produto da produção social capitalista que acontece e se reproduz desigualmente, sociedade e espaço, conseqüentemente, trazem consigo desigualdade e fragmentação. Desigualdade essa que é criada a partir da relação de dominação e 
subordinação ligada fortemente ao processo centralizador de propriedade e poder.

A urbanização apresentada hoje foi gerada pela industrialização e pelo processo de apropriação privada da terra, elemento base para 0 desenvolvimento do capitalismo e, apresenta características bastante peculiares com aspectos e significados diferentes. As disparidades espaciais estão presentes no crescimento e desenvolvimento das cidades, produzindo espaços diferenciados e desigualmente desenvolvidos.

As contradições urbanas são resultado do crescimento rápido das cidades e da urbanização acelerada e sem controle, onde o Estado se coloca a serviço do setor privado, privilegiando os setores economicamente mais poderosos. O espaço urbano se reproduz, desta maneira, produzindo segregação e desigualdade. Durante o processo de formação das cidades 0 poder público deu privilégios para uma pequena parcela da sociedade brasileira, e desta forma, alguns interesses foram privilegiados em detrimento de necessidades gerais da sociedade. Questões familiares e elitistas se sobrepuseram a questões fundamentais ao desenvolvimento do país

O crescimento urbano se dá concomitantemente ao desenvolvimento da industrialização e traz uma nova variedade de problemas que tem de ser enfrentados pela população e pelo poder público.

Nos últimos 50 anos o poder público passa a exercer um papel extremamente ativo na produção da cidade. O Estado com seu aparato legal é responsável pelas transformações no uso do espaço e nas funções da cidade. É na forma como o poder público direciona seus investimentos, que trata de grandes obras e operações no espaço urbano, que as desigualdades espaciais e sociais tendem a se aprofundar e também contribuem para a valorização diferencial do solo urbano.

Nesse momento é necessário expormos algumas considerações sobre a história política da cidade de Rio Claro, que se insere no contexto brasileiro.

\section{O Contexto Político}

Para podermos ilustrar de maneira prática as reflexões que serão apresentadas sobre democracia participativa discutiremos a prática de gestão democrática que está sendo realizada em diversos municípios de nosso país e 
que demonstra de maneira bastante explícita as desigualdades espaciais e sociais que encontramos na cidade, devido a apropriação privada do espaço urbano em nossas cidades.

Quando analisamos a prática participativa de gestão da cidade de Rio Claro não podemos nos esquecer que estamos falando da questão política de um município que sempre conviveu com o clientelismo e o elitismo político. Rio Claro, como a maioria dos municípios do interior paulista, tem na sua história política, questões bastante preocupantes e que nos levam a melhor compreender a situação atual da política local.

Do período colonial, passando pela Primeira República, pela Ditadura de Vargas e até nossos dias observamos que o poder político sempre esteve nas mãos da pequena elite social e econômica local e, que a grande maioria da população nunca teve acesso a participação política direta.

No livro "As Elites Políticas de Rio Claro" (BILAC, 2001), a autora coloca que a partir de 1945 a população de classe inferior (sic) passa a ter acesso ao voto e por isso alcança a cidadania, mas até que ponto o voto é a conquista da cidadania? Até que ponto, conforme afirma a autora, o voto dá uma "dose razoável de poder" para a classe trabalhadora sobre os dirigentes políticos?

A conquista da cidadania não passa somente pela aquisição dos direitos políticos instituídos, como o sufrágio universal. A cidadania se conquista com a aquisição de direitos civis, direitos políticos e direitos sociais, que em nosso país, não foram alcançados igualitariamente por toda nossa população.

A industrialização e a urbanização acelerada fizeram com que os políticos passassem a exercer uma nova forma de "fazer política", o que não trouxe modificações substanciais na relação e no trato com a maioria da população, continuou-se privilegiando interesses elitistas e econômicos em detrimento aos interesses gerais da população, isso não significa, obviamente, uma melhora para a população das relações que essa tem com os dirigentes políticos. O que aconteceu após a conquista dos direitos políticos no Brasil foi um aumento do eleitorado e não um aumento da representação da população junto aos setores públicos administrativos, o eleitorado aumentou, mas a continuidade da defesa dos interesses de uma minoria e da concentração do poder foi mantida. Os representantes políticos simplesmente alteraram suas 
estratégias de ação junto à população para cooptação e ganho de seus votos. Podemos dizer que, com o intenso crescimento das cidades e o aumento da população urbana houve também um grande aumento do número de eleitores. A partir disso instaura-se no Brasil, e também em toda a América Latina, uma nova forma de relação entre representante e representado, conhecido como populismo. O populismo é na verdade uma alternativa criada para abarcar a rápida urbanização trazida pelo advento da industrialização, nos países subdesenvolvidos, no século XX, pois a intensa urbanização ocorrida em tão pouco tempo trouxe a impossibilidade de manter o sistema tradicional do poder, pela elite política local, que perde a tutela direta sobre seu eleitorado e encontra, então, no populismo a alternativa para continuar concentrando poder. A classe política se vê incapacitada de barrar e neutralizar a força que passa a se formar com a grande concentração de trabalhadores. O populismo aparece como a maneira mais eficaz de controle social onde a classe trabalhadora é inserida no processo político, através do voto, mas não intervém no sistema político tradicional existente. Direitos políticos dão à população uma influência política, ou seja, a capacidade de alterar marginalmente as decisões tomadas pelos governantes, sem no entanto, chegar a modificar o essencial que é a direção geral do processo de tomada de decisões governamentais. O que se cria é uma ilusão prática, que é a idéia de que todos, independente de sua condição socioeconômica, estão participanto do exercício político. A inclusão do voto dos trabalhadores, não significou a mudança na condição de excluídos do sistema político. No Brasil, o populismo teve seu auge no período de 1946 a 1964 onde se procurou, através de mecanismos ideológicos, apagar ou minimizar os interesses das classes divergentes da elite política, impedindo assim uma ação política autônoma da classe trabalhadora.

Em um município onde desde a colônia as relações políticas foram estabelecidas com a participação de uma pequena elite que se manteve no poder sempre através de casamentos, negócios e que defendia interesses próprios deixando os trabalhadores à margem da participação política e de sua representação, o voto pode figurar como um avanço para a democracia, porém não podemos nos esquecer que o direito ao voto não traz para as pessoas a consciência sobre a importância do ato de votar. 
Prova disto é que eleição municipal de 2004 ficou conhecida, no município de Rio Claro, como a eleição da cesta básica, porque muitos moradores carentes da periferia trocaram seus votos por uma cesta básica oferecida por alguns candidatos. Difere-se muito pouco este fato do qual descreve Ferraz, no Álbum de Rio Claro, 1922:

"É interessante notar-se o systema eleitoral usado e as encarniçadas contendas entre chefes e eleitores. Tres dias durava a chamada Votação, e, durante as noites, as urnas eram guardadas por pessôas de absoluta confiança e prevenidissimas. O votante, typo boçal, furtado as lides da roça, gosava de agrados de confundir e lhe não faltava bom companheiro para os passeios. O voto equivalia a um terno ou sapatão que sacrificava, martyrisava o pobre caboclo desaffeito ás exigencias da moda. Cada partido tinha o grosso das forças completamente presas nas hospedarias especiaes denominadas - Viveiros. O Visconde do Rio Claro installára o seu viveiro numa casa da Bôa Morte, que não conseguimos localisar, e o do sr. Teixeira das Neves no predio da rua 5 esquina da avenida 2 , hoje provisoriamente mercado municipal. Desses viveiros o eleitor só sahia para dar uma "voltinha" e votar. La tinha tudo: cama, comida e até roupa lavada, se preciso fosse..."

Esta citação refere-se a eleição de 1872 no município de Rio Claro, ainda no período monarquista brasileiro, quando a idéia da República passa a fortificar-se em nosso país e, em Rio Claro também. Teixeira Neves representava as idéias republicanas em Rio Claro, enquanto Visconde do Rio Claro defendia a monarquia no país. Trata-se de uma citação que demonstra, de maneira bastante clara, como se estabeleciam às relações entre votantes e votados no município neste período, mas infelizmente observamos que embora se tenham passado mais de 100 anos do fato ocorrido e as relações políticas tenham-se alterado, algumas relações permanecem, pela questão da educação política que é tão pouco explorada e tão inexpressiva em nossa sociedade, reflexo da condição de vida dessa população, da estratégia de sobrevivência alcançada, que não contém necessariamente uma estratégia política, mas que se reflete diretamente nesta devido a pouca importância que 
a população dá ao poder do voto. Vemos que as pessoas ainda decidem seu voto com base em questões clientelistas, de parentesco, de amizade.

Em todo seu livro Bilac (2001) demonstra que nas composições políticas de nosso país e em especial da cidade de Rio Claro, as alianças políticas e as conciliações entre os diferentes atores políticos existiam e descaracterizavam seus ideais, que talvez nem existissem, pois as relações políticas baseavam-se em questões individuais. $\mathrm{Na}$ verdade, os partidos políticos não possuíam uma identidade política, eles apenas defendiam os interesses primeiramente, da oligarquia rural que se manteve no poder durante muitos anos, seja através do exercício direto de funções políticas, seja através de apadrinhamentos, casamentos e/ou posse de terras. E, posteriormente, defendiam os interesses da burguesia industrial que se fortalecia nas cidades, através de sua influência econômica e que garantia a conquista de seus interesses através de conchavos políticos, alianças e coligações que não podiam ser compreendidas pela população. Todos os esforços para as coalizões advinham da necessidade da elite se manter no poder e de conquistar seus objetivos políticos e econômicos, criava-se uma rede de lealdades que se perpetuou pela necessidade de continuidade do exercício do poder.

Por muitas décadas a família foi um elo que unia os interesses e assegurava a defesa destes, através das ações do poder político, depois disso, o quadro que nos é apresentado é a união por interesses econômicos, ou seja, os sujeitos da sociedade que possuíam os mesmos interesses se uniam, através da política, para concretizá-los.

Hoje a situação que encontramos traz diferentes elementos da situação apresentada. A dominação política oligárquica, patrimonial reveste-se da modernidade, através de um disfarce burocrático-jurídico-racional e, conseqüentemente, as relações políticas atuais continuam a serem quase as mesmas de nossa tradição política. $O$ aparelho estatal modernizado apresentase à disposição da política oligárquica e estes se utilizam muito bem deste aparelho e detêm o domínio político mantendo a legitimidade do seu poder.

"Em conseqüência, nenhum grupo ou partido político tem hoje condições de governar o Brasil senão através de alianças com esses grupos tradicionais." (MARTINS, 1999 p. 20) 
O resultado é o engessamento das possibilidades da governabilidade municipal, estadual e federal. O grau de enraizamento das práticas de alianças e coligações políticas-econômicas em nosso país tomou proporções enormes, se tornou a prática mais comum no "fazer política" e por este motivo, se torna de difícil dissolução. Governar sem pactuar ou minimamente se aliar aos grupos tradicionais constituídos é tarefa bastante complicada.

As relações políticas dominantes em nosso país, sempre se basearam na relação com os proprietários de terra e proprietários dos meios de produção e sempre contaram com o apoio do Estado, visto que, ou eram os próprios proprietários que estavam no poder, ou eles manipulavam os que ocupavam cargos políticos.

O quadro histórico-político apresentado em nosso país não se difere do quadro apresentado no município de Rio Claro que é o de alianças políticas feitas através de interesses individuais; falta de uma ideologia política concreta que defendesse os interesses gerais da população e não interesses particulares; a troca de favores sendo um importante fator de decisão do voto e das coalizões políticas não ideológicas; organização política social baseada no favor e não no direito; laços familiares e de amizade como elemento decisivo nas relações políticas e do voto; presença de algumas mudanças estruturais na tomada de poder sem trazer grandes mudanças na estrutura ideológica e política das ações que são realizadas; protecionismo e assistencialismo como fonte de votos; a não identificação da massa por partidos políticos; defesa dos interesses das elites sociais, através do poder político; a mídia, através da imprensa local, sempre a serviço de uma corrente política partidária; deslealdade dos ideais políticos defendidos por uma classe, devido a questões individuais financeiras, classe que elege seu representante e esse não defende os interesses dessa classe social.

Mas a partir da década de 80, após alguns ensaios durante fins dos anos 70, a questão do Orçamento Participativo (OP) está posta em nosso país, com o Partido dos Trabalhadores (PT) chegando ao poder na cidade de Porto Alegre - RS. Esse instrumento de gestão da cidade tornou-se ícone no Brasil e em todo mundo, por tratar-se de uma experiência inovadora onde a administração municipal convoca a população para opinar e trabalhar sobre parte do orçamento municipal. 
Com o passar dos anos as práticas do OP multiplicaram-se pelos municípios brasileiros, atingindo também alguns municípios da América Latina e Europa, mas ainda não são muitas as experiências.

Inicialmente, no Brasil, essa prática tinha uma estreita ligação com o PT, porém amplia-se, posteriormente, para práticas executadas por diversos partidos políticos de ideologia progressista de centro-esquerda. Apresentando inúmeras variações na maneira de realizar o OP, incluindo os OPs de fachada.

$\mathrm{Na}$ eleição de outubro de 1996 os municípios brasileiros elegem vereadores e prefeitos para governarem seu território e, no Município de Rio Claro, a partir de janeiro de 1997, assume o governo uma nova administração municipal, com idéias progressistas, que se aproximam mais da população e da idéia de redemocratização da cidade.

A história da produção do espaço do município de Rio Claro não difere da história de formação do estado de São Paulo, de maneira geral. A urbanização acelerada e a especulação imobiliária, que se concentra principalmente nas áreas centrais da cidade, fruto da apropriação privada do território municipal fez com que os trabalhadores procurassem as áreas mais periféricas da cidade, devido ao menor custo de se viver nessas áreas, que ainda não possuem grande interesse comercial aos empreendedores imobiliários. O lugar que esta população ocupa no processo de trabalho determina imediatamente seu modo de vida e o lugar que ocupa no espaço urbano.

O município de Rio Claro possui, há mais de 50 anos, sua população predominantemente urbana. Em 1950, 75,5\% da população rio-clarense era urbana; em 1970, essa taxa chega a 89,3\%. Em números absolutos a população urbana sobe de 35.549 em 1950, para 69.682 em 1970, ou seja, um aumento de $51 \%$ em apenas duas décadas.

Assim como a grande maioria dos municípios paulistas, a industrialização e a mecanização do campo trouxeram para a cidade um grande número de pessoas. O crescimento da urbanização implicou na expansão da malha urbana do município, novas áreas foram ocupadas e a alta valorização de áreas próximas ao centro, junto com a especulação imobiliária, fez com que um grande número de pessoas se afastasse da área central, provida de toda infra-estrutura necessária, e buscassem em áreas cada vez 
mais distantes, terrenos, casas e aluguéis mais acessíveis para a população de baixo e médio rendimentos.

A reprodução social que nos é apresentada no município é conseqüência também de medidas adotadas pelo governo federal que influenciaram inúmeros municípios de nosso país. O Brasil passou por diversos processos, que em menos de 30 anos, transformaram e modificaram algumas regiões brasileiras e também as relações sociais que aconteciam nesses lugares: a desruralização, o êxodo rural, as migrações, a urbanização concentrada e acelerada, a expansão do consumo de massa, o crescimento acelerado da economia, a degradação do sistema de ensino e o domínio da mídia, são exemplos de processos que levaram a formação de consumidores individualistas e não cidadãos em nosso país. A sociedade urbana cresceu sem se desenvolver, a apropriação privada do espaço urbano e a individualização, fizeram com que os moradores que ocupavam esses espaços não se sentissem parte dele, eles eram alheios a quase tudo que acontecia a seu redor.

O período do chamado "milagre econômico" (1968-1974) trouxe para a nossa sociedade uma ampliação da classe média, que passa a adquirir mais bens de consumo. Com sua força ideológica e política, este período trouxe para os estratos de rendimentos médios da população uma sensação de bemestar e a impressão de realização pessoal, através do consumo de "necessidades" criadas pela produção e veiculadas pela mídia, principalmente, que é uma das ferramentas responsável pela transformação do indivíduo em consumidor, comandada pelo poder econômico. Consumir, muitas vezes é o desejo da população, que influenciado fortemente pela mídia vê nessa ação a possibilidade de ser reconhecida e de desempenhar um papel importante na sociedade, o reconhecimento pelo ter e não pelo ser se intensifica entre a população. A prosperidade desejada por todos, é fruto do trabalho e do consumo e a classe média é seu melhor exemplo. As pessoas se realizam enquanto consumidores. É a efetivação do modo de produção capitalista.

Até mesmo o lugar onde se vive, onde se freqüenta, o consumo dos lugares, determina a posição que se ocupa na sociedade capitalista. Se considerarmos a localização das pessoas na cidade, veremos que na maioria das vezes, ela é fruto de uma combinação das forças do mercado com as 
decisões governamentais e o indivíduo não escolhe livremente o local onde vai habitar, isto é determinado pelas forças econômicas.

O lugar que o homem ocupa no processo de trabalho também determina de maneira direta o seu lugar na distribuição de riqueza, o que instantaneamente corresponderá a um modo de vida, incluindo aqui acesso ao local e tipo de moradia, lazer, cultura, educação. Tudo isso sendo determinado no processo de produção. A população mais carente que não consegue pagar para viver em áreas centrais da cidade, onde toda a infra-estrutura está instalada, busca na periferia, áreas não ocupadas ou, se vive no centro, está em lugares degradados.

O espaço urbano da periferia ocupado pela população rio-clarense carece de infra-estruturas que proporcionem à população melhor qualidade para a sua reprodução social. O espaço em que esta população está inserida apresenta um elenco de necessidades que, muitas vezes, estão ligadas à expansão urbana acelerada que o município sofreu a partir da década de 70 , causada pelo processo de produção industrial capitalista.

Esse distanciamento das áreas centrais e mais providas de serviços, traz para a Prefeitura Municipal, necessidades de novos investimentos em infra-estrutura e serviços: casas populares, água, esgoto, iluminação, segurança, transporte público, saúde, educação, lazer. Porém os locais determinados para a implantação desses serviços têm de receber o aval da Câmara Municipal, que diversas vezes irá defender interesses próprios, permitindo que recebam esses benefícios os loteamentos que os interessam individualmente, para que possam lucrar com a especulação imobiliária. Esta gama de obras necessárias à reprodução da vida na cidade é requerida por toda a população, que quer ter na sua casa o mínimo para viver e sobreviver e que nos bairros centrais de sua cidade tais serviços já são oferecidos. Para que não haja discriminação dos locais onde os indivíduos vão morar é necessário que toda a cidade seja provida de toda a infra-estrutura necessária para a reprodução da vida, e esse é um dever do Estado. As obras e instituições públicas devem servir a todos os indivíduos. O acesso à educação, moradia, lazer e saúde aparecem hoje como conquistas pessoais dadas pelo poder aquisitivo que os indivíduos possuem, e não como direitos sociais, o que realmente são. 
As reuniões do Orçamento Participativo deixam bastante claro para nós que é a parcela da sociedade economicamente mais carente, a margem do processo de produção capitalista e da distribuição de riqueza, que busca junto ao poder municipal o fornecimento das obras e serviços que eles não possuem em seu lugar. As desigualdades existentes no espaço urbano são produzidas pelo sistema capitalista e pela divisão do trabalho e evidenciam-se claramente no OP.

A nova organização do trabalho e as modificações no processo de trabalho são também apresentadas no processo do Orçamento Participativo, quando os cidadãos buscam nas reuniões ajuda e soluções para os problemas de desemprego e de desqualificação profissional. Essas pessoas se sentem excluídas do processo do trabalho formal e esperam que o poder público municipal os ajudem a se reproduzir socialmente. Até o momento a iniciativa tomada para tentar amenizar essa questão, no OP de Rio Claro, foi a de realização de cursos de qualificação profissional, em diversas áreas. Porém, a questão colocada é: até que ponto essa qualificação os insere no mercado de trabalho? É certo que novas tentativas devem ser buscadas, seja pelo poder público, seja pela sociedade organizada.

A institucionalidade política e a distribuição desigual de recursos políticos na sociedade capitalista geram condições desfavoráveis para a participação política da população, segundo Saes (2003 p. 34)

"um salto qualitativo na participação política só poderia ser iniciado, no seio da sociedade capitalista, com a deflagração de um surto democrático na periferia do sistema político global, mais precisamente, na esfera econômica (empresas, unidades de produção) e na esfera política local ( distritos, municipalidades, etc)"

O autor reforça que para o aprendizado e a apropriação da participação na macropolítica há que se começar com a participação em microesferas da vida social, ou seja, em empresas e instituições políticas locais. Com as diversas práticas de partipação popular, nos governos locais, que tem se implantado nos últimos 20 anos, podemos visualizar a incipiência de um maior interesse da população pelo político e pelo público, ao menos, daquelas que participam das diversas atividades propostas pelos governos. Porém, não pode nos escapar, que o OP, por exemplo, - que é a prática participativa inserida, 
dentro de um sistema democrático representativo, mais conhecida dentro dos governos locais no Brasil e até mesmo no exterior - conta com grande mobilização entre a população e participação regular devido ao seu caráter redistributivo, com relação às obras de infra-estrutura e melhorias na reprodução da vida. A população se dispõe a participar, pois sabe que ali existe uma possibilidade de ter suas necessidades imediatas da vida supridas, sabe que ali suas prioridades podem ser atendidas. É a busca pelo direito de sobrevivência que não foi suprido, embora tenha sido prometido, pela declaração dos direitos civis.

Porém, esta participação está longe de ser aquela colocada por Saes (2003 p.34), baseado nas idéias de Pateman (1992) que diz:

"empurrarão as massas para o exercício de uma pressão
participativa sobre as instituições democrático-representativas
clássicas, e tal movimento pode levar à implantação de novos
mecanismos democráticos, que concretizem a participação
das massas no poder político"

O quadro de participação popular que analisamos nesta dissertação, no município de Rio Claro, não tem esse caráter popular de pressão participativa. Ele foi totalmente organizado e comandado pelo governo local e não incorporado a prática cotidiana da população, prova disto é que após a derrota da candidata a sucessora, do então prefeito Cláudio Antônio de Mauro, na campanha eleitoral municipal de 2004, o prefeito que assume a administração municipal, Demerval da Fonseca Nevoeiro Junior - PFL, extingue totalmente o processo do orçamento participativo, não realiza as obras decididas pela população durante o OP 2004/2005, que haviam sido incorporadas a Lei Orçamentária Anual de 2005, e com tudo isso não houve nenhum protesto significativo da população em relação a esta situação.

" Uma cidadania plena e ilimitada, conforme as exigências ideológicas subjacentes ao conceito apresentado por Marshall, situa-se além do horizonte da sociedade capitalista e das suas instituições políticas." Saes (2003, p. 38)

Para o Estado o espaço é instrumento da ação, pois se utilizando conhecimentos e técnicas, através de planos e programas, o Estado controla, domina e exerce seu poder produzindo uma hierarquia dos lugares, baseados em suas aspirações. Cria um poder central que estabiliza o sistema territorial e reforça sua capacidade de resistência à mudança social e é a administração 
que vai formular as demandas sociais, através de seus processos de planificação e ordenação do território.

É através de seus processos de planificação do território, que a valorização-desvalorização dos lugares se definirá, dependendo de sua localização dentro ou fora do ponto estratégico, dos lugares estratégicos que pretendem a permanência e a reprodução do sistema mundial.

"O que há de moderno no processo de produção, hoje, onde as forças sociais estão apoiadas na técnica e no conhecimento é a intervenção do Estado no espaço através de instituições consagradas à gestão e à produção do espaço. Tal fato permitiria, para o Autor [Lefebvre], reintegrar o espacial no pensamento político e, com isso, precisar a estratégia: autogestão da base social e territorial, controle social da produção." (CARLOS, 1996 p. 53)

De outro lado, encontramos a estratégia do social, a estratégia da população, que tem como maior objetivo a vida na cidade, sua participação junto a gestão da cidade está mediada pela conquista de prioridades, de reivindicações que dizem respeito a questões imediatistas, que não foram oferecidas pelas administrações anteriores. Trata-se da reivindicação do mínimo e não se aproxima do entendimento da vida urbana, do direito à cidade.

O OP, na grande maioria de suas experiências, é proposto por prefeitos progressistas que tem por objetivo implementar uma nova forma de governo que conte com a transparência, a participação da população e a inversão de prioridades públicas urbanas. O OP surgiu como um instrumento de gestão que traz mudança na relação sociedade-Estado e tem por objetivo transformar a cidade e a sociedade, através da reinvenção da governabilidade municipal. Muito da idéia relacionada ao orçamento participativo é ligada a vontade de rompimento com o capitalismo, ao menos nos discursos políticos dos prefeitos que propõe o processo, a idéia de não mais o capital estar à frente das relações humanas e sociais, que a cidade possui. A idéia é não só inverter as prioridades centro-periferia, mas também inverter a prioridade capital-direitos humanos. Para alcançar estas inversões a participação popular é o instrumento utilizado na lógica de união dos saberes e das inteligências.

O grande marco, o mais utilizado, o mais famoso processo de participação popular, hoje, é o orçamento participativo, mas por quê? Será porque o OP discute orçamento, dinheiro e, é este o maior instrumento de 
trabalho durante as reuniões propostas pelo governo, é esta discussão que atrai um grande número de pessoas, pois este é o instrumento (dinheiro), que as pessoas tem interesse em discutir, que elas acreditam que vão solucionar seus problemas. Os políticos progressistas que desejam romper com 0 capitalismo utilizam-se dele para propor uma nova maneira de governar. O OP é um processo dialético, pois ele é implantado por governos progressistas que não querem que o capital esteja acima das relações humanas, mas utilizam-se dele para conseguir reunir a população e debater sobre justamente, o capital e o orçamento.

A cidade e o direito à cidade não são discutidos nos momentos do $\mathrm{OP}$, não existe uma apropriação destes conceitos. O que é discutido são os investimentos, desenvolvimento, - palavra que custou tão caro a nós brasileiros - o orçamento. Não se discute a democracia, se discute capital.

Surge a pergunta: o OP utiliza-se do capital e de suas táticas para alcançar seu objetivo maior que é a instauração da democracia participativa, a reinvenção da governabilidade, a inversão de prioridades; ou é o capital que está intensamente imbricado no OP e o domina, transformando-o em um instrumento para a perpetuação e legitimação do capitalismo?

Não há como negar, que os ganhos e avanços do OP não se resumem a construção de obras e implantação de serviços. O OP supera isso através da intensificação da educação e da formação da população que participa do processo e, através, dos laços de solidariedade e amizade que se criam e fortalecem na cidade. No entanto, são ainda os resultados concretos e práticos que a população busca quando participa dessas reuniões, o restante é conseqüência do processo, bastante benéfica, mas não o objetivo final percebido e reclamado pela população.

O OP é uma ação inovadora e recente na cidade, que se centra na tentativa do governo de trazer a população para participar e se aproximar da administração municipal. Este instrumento estabelece uma nova relação entre Estado e sociedade, relação essa mediada pela gestão de um território e pela vida no lugar. A aproximação da população à gestão municipal gera um conflito entre interesses e estratégias diversas, já que por um lado temos a estratégia do político exercida pelo Estado, no caso específico, pelo governo municipal, que possui objetivo, lógica e racionalidade baseados na normatização e 
legislações e mantidas por alianças políticas que dominam e gerem o território através de acordos estabelecidos. Do outro lado, encontramos a estratégia do social, a estratégia da população, que tem como maior objetivo a vida na cidade, sua participação junto a gestão da cidade está mediada pela conquista de prioridades, de reivindicações que dizem respeito a questões emergenciais, que não foram oferecidas por administrações anteriores. Trata-se da reivindicação do mínimo e não se aproxima do entendimento da vida urbana, do direito a cidade.

O OP não traz em si uma revolução que dá autonomia para a sociedade e emancipação para os cidadãos, o processo é uma evolução em relação ao que estava posto mediante as relações entre Estado e sociedade civil. Podemos identificar no OP uma lógica de melhoramento da gestão, com a participação da população nas decisões orçamentárias do município. Traz uma lógica social de inversão de prioridades e de construção de novas relações entre sociedade civil e governo.

O OP vai revelar a fragmentação do espaço urbano através das reivindicações feitas pela população. As reivindicações por infra-estrutura básica revelam os fragmentos do espaço que tem e os que não tem essa infraestrutura. Revela a segregação da população. Segregação que é a negação do urbano e da vida urbana, pois não permite a apropriação e o uso do espaço urbano. 


\section{Capítulo 2 - Práticas Participativas na Gestão da Cidade: o orçamento} participativo em Rio Claro/SP.

O Orçamento Participativo em Rio Claro/SP começou a vigorar efetivamente no ano de 1998. Embora seja em 1997, que o novo governo assume a Prefeitura Municipal de Rio Claro, com a eleição de Cláudio Antonio de Mauro, do Partido Verde, através da coligação partidária: PV, PT, PMDB, PC do B, PPS, PDT e PSC ${ }^{2}$, o governo decide em seu primeiro ano realizar apenas uma consulta junto à população, feita através de visitas aos bairros de toda a cidade, para que a nova administração tivesse maior contato com a população e os problemas e necessidades enfrentados. Somente em 1998 que o processo do Orçamento Participativo (OP) se efetua na cidade.

No primeiro ano de implantação do OP, a administração municipal optou realizar reuniões em todos os bairros das cidades, a exemplo do que tinha ocorrido no ano anterior, mas agora com metodologia e objetivo diferente. Aconteceram duas reuniões em cada um dos 120 bairros da cidade, onde seus moradores podiam opinar e indicar demandas para seus bairros e, posteriormente estabelecer as principais prioridades das demandas indicadas. Essa maneira de organização do processo mostrou-se inviável, pois na cidade existiam mais de 120 bairros e a equipe técnica era pequena, assim como, a verba destinada para a execução das prioridades era bastante reduzida, o que dificultava a sistematização das prioridades, já que a quantidade de demandas era numerosa e diversificada.

Já no segundo ano do OP, 1999, a equipe técnica optou por dividir a cidade em 16 regiões, para que houvesse uma melhor organização do processo e também para que existisse uma maior socialização dos conhecimentos e realidades entre os bairros. A divisão regional foi realizada baseada em critérios de semelhanças econômicas e sociais entre os bairros e também de proximidade entre eles, para que as regiões tivessem uma continuidade espacial. Ocorreu uma generalização das características em algumas regiões, 0 que se mostrou bastante positivo posteriormente, devido ao trabalho realizado conjuntamente entre realidades bastante diversas encontradas no município, trazendo para os moradores uma visão mais ampliada e mais realista sobre toda a cidade.

\footnotetext{
${ }^{2}$ Ver significado das siglas e fundação dos partidos página 139
} 

em Rio Claro/SP.

As regiões 1 a 11 e 17 - formada por bairros, incluídos no perímetro urbano do município. Cada região contém aproximadamente 10 bairros.

Já as regiões 12 a 16 - distritos e bairros rurais pertencentes ao município de Rio Claro/SP. Cada região corresponde a 1 bairro rural ou distrito. Não existe um agrupamento devido à distância física entre eles. 

em Rio Claro/SP.

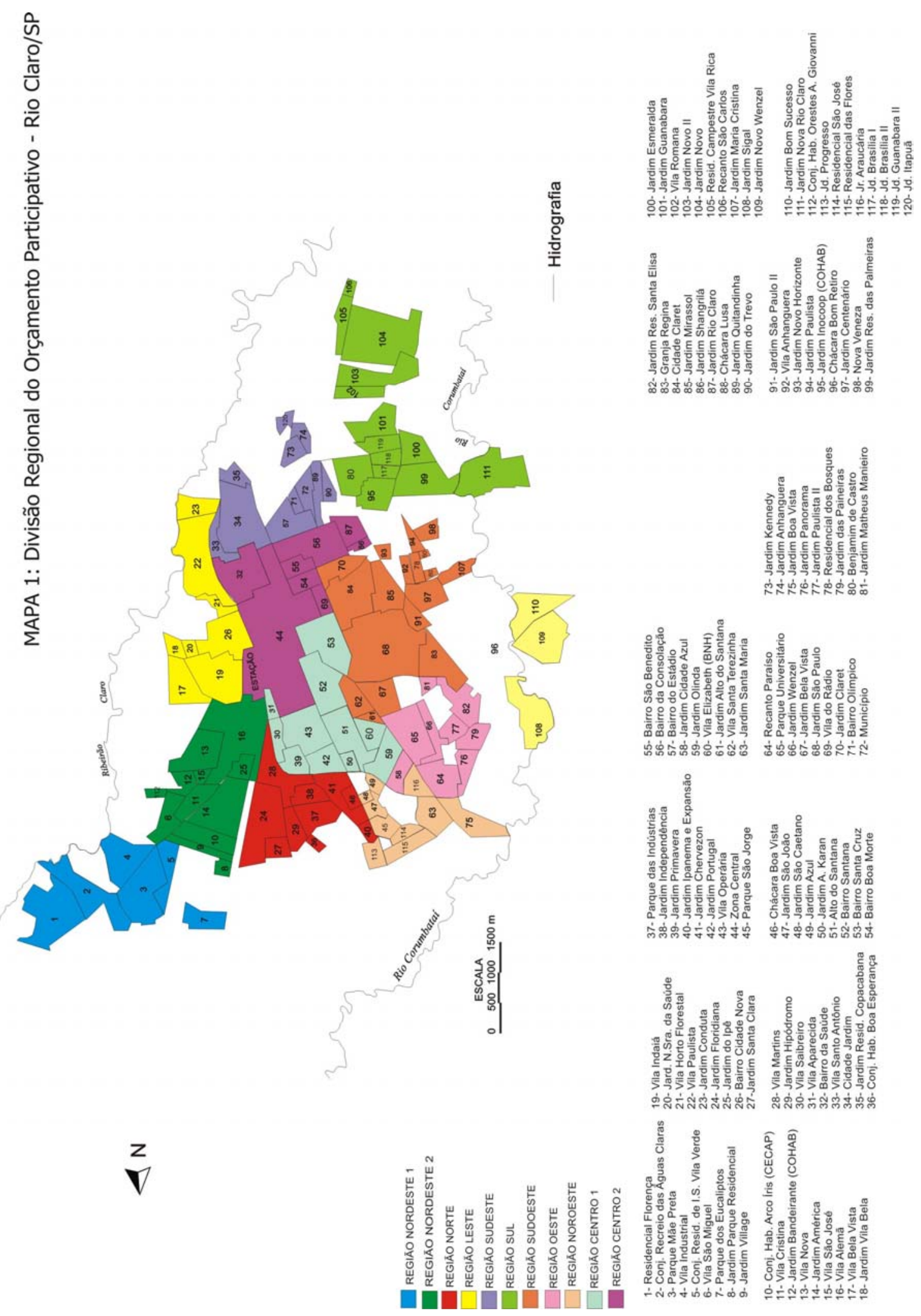


A atual divisão apresenta 17 regiões. A $17^{a}$ região, foi criada em 2002, após a reivindicação de dois bairros pertencentes à região 7 , que estavam muito distantes fisicamente dos demais bairros e do núcleo urbano, o que dificultava a participação dos moradores desses 2 bairros, que não possuem condições financeiras para deslocamento até o lugar da reunião regional. Foram realizadas algumas outras alterações nas regiões, sempre solicitadas por moradores de bairros, que as julgavam necessárias para ampliar a participação da população.

\section{Contexto Espacial das Regiões do Orçamento Participativo}

Após apresentarmos como se deu a formação espacial da cidade de Rio Claro e analisar seu processo de ocupação e sua história política é necessário observarmos como o espaço geográfico da cidade se apresenta hoje. Para realizar esta análise utilizaremos os mapas de expansão urbana da cidade e o mapa de rendimentos, em salários mínimos. As regiões definidas para a execução do orçamento participativo da cidade serão o nível de análise utilizado, pois assim poderemos compreender melhor as demandas discutidas pela população.

O mapa 1 - Divisão Regional do OP Rio Claro - SP representa como a cidade foi dividida para que fosse possível realizar as reuniões com a população. $O$ mapa apresenta 12 das 17 regiões, isto porque, existem 5 regiões que não se encontram no perímetro urbano de Rio Claro. Tratam-se de distritos e vilas rurais, que não serão analisadas nesta dissertação, pois nosso objeto de pesquisa centrase no espaço urbano. Em nossa análise nos concentraremos em discutir e apresentar os dados das regiões que encontram-se na área urbana da cidade. 


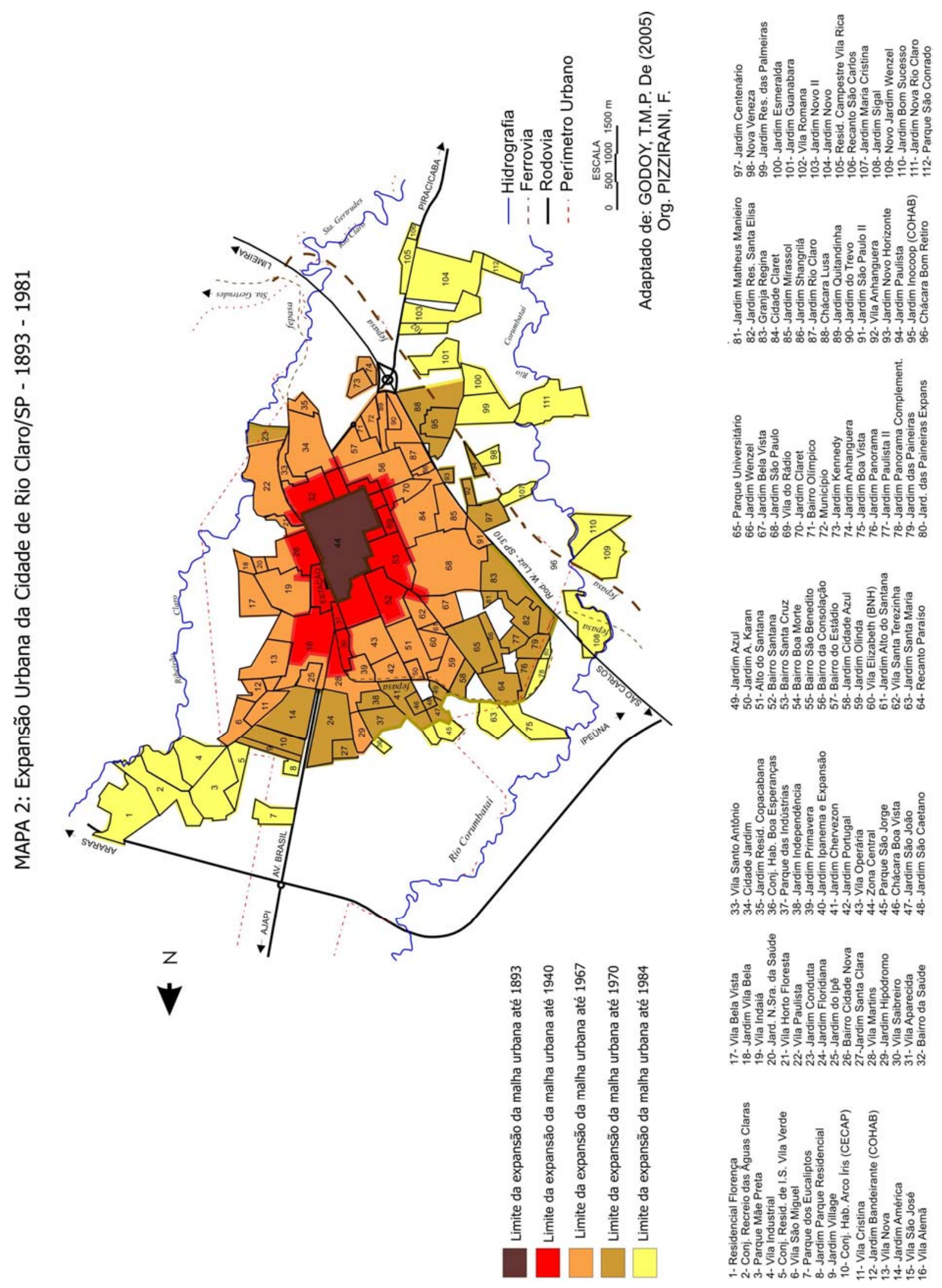




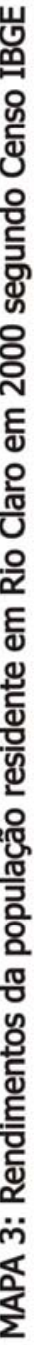

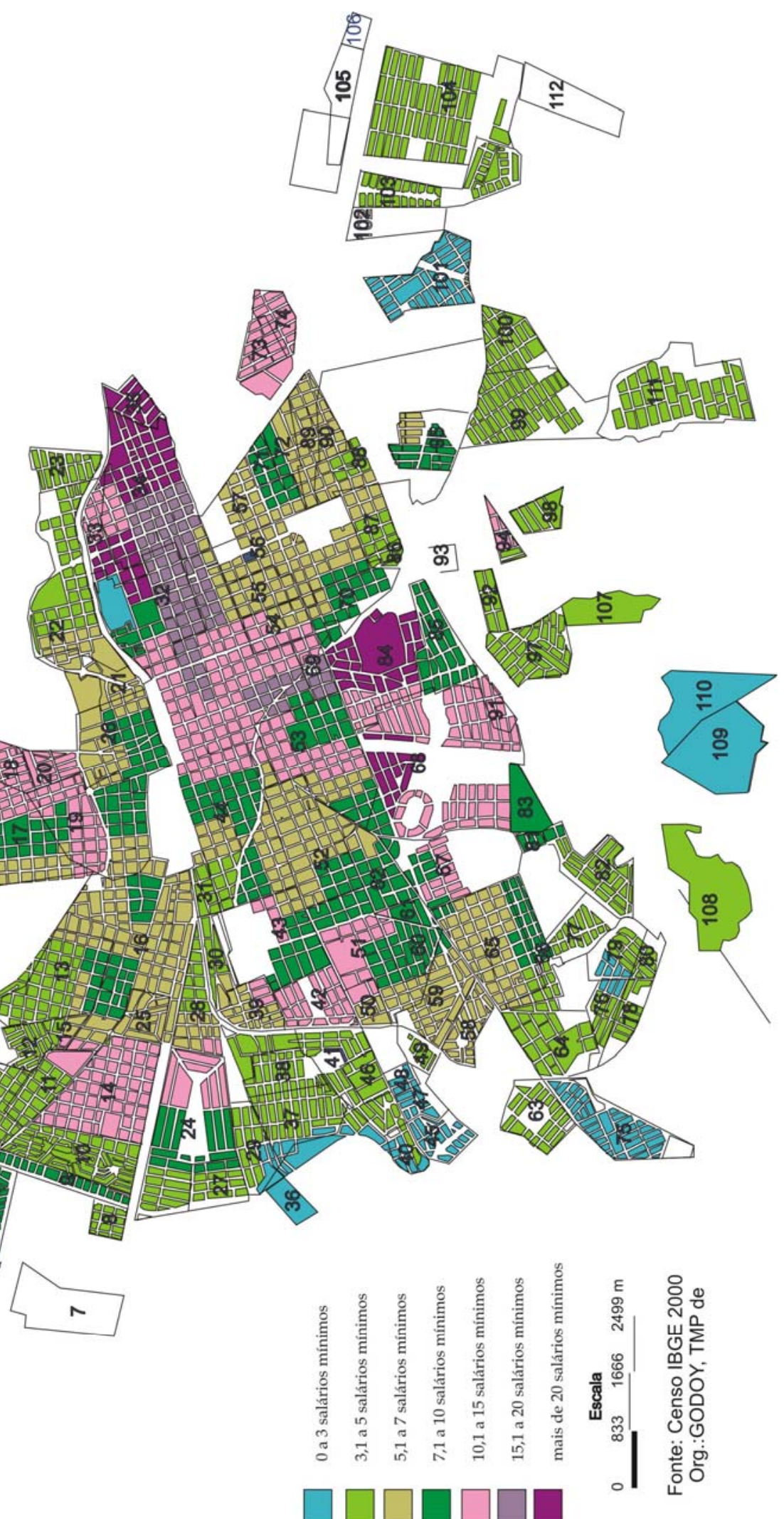



em Rio Claro/SP.

As regiões do OP de Rio Claro são denominadas por um número e um nome. O nome refere-se a sua localização baseada nos pontos cardeais, com exceção das regiões localizadas fora da área urbana, estas regiões recebem o nome das vilas ou distritos que a compõem. A denominação das regiões do OP utilizada pela Prefeitura Municipal de Rio Claro era a seguinte:

Região 1 - Nordeste I; Região 2 - Nordeste II; Região 3 - Norte; Região 4 - Leste; Região 5 - Sudeste; Região 6 - Sul; Região 7 - Sudoeste I; Região 8 - Oeste; Região 9 - Noroeste; Região 10 - Centro I; Região 11 - Centro II; Região 12 Assistência (Distrito); Região 13 - Ajapi (Distrito); Região 14 - Ferraz; Região 15 Batovi; Região 16 - Itapé (Vila rural) e, Região 17 - Sudoeste II.

Analisaremos os dados coletados através deste corte regional, para que tenhamos uma melhor compreensão do que essa parcela do território representa para a cidade. Qual o papel desempenhado na produção do espaço urbano e o que as demandas do OP apresentadas nestas regiões revelam para nossa análise.

A região 1, chamada de Nordeste I, é composta por 5 bairros e tem uma população de 7.950 habitantes. Todos os bairros são de ocupação recente, entre 1970 a 1984, caracterizando-se como novos loteamentos. Os bairros Residencial Florença e Conjunto Recreio das Águas Claras são compostos de chácaras e residências de alto padrão utilizados, muitas vezes, como casas de final de semana e, não, como residência fixa. Quando analisamos o mapa da Expansão Urbana de Rio Claro (mapa 2), verificamos que se trata de uma região bastante afastada do centro da cidade e muito próxima à rodovia que liga os municípios de Rio Claro e Araras. Observando o mapa de Rendimentos da População em 2000 (mapa 3), construído através de dados do Censo do IBGE de 2000 e baseados nos setores censitários, verificamos que se tratam de bairros onde a população tem seus rendimentos concentrados na faixa de 7,1 a 10 salários mínimos (s.m.), com exceção do bairro Parque Mãe Preta, onde a população tem seus rendimentos concentrados nas faixas de 3,1 a 5 s.m. e 5,1 a 7 s.m. O que nos surpreendeu na análise desta região foi a faixa de rendimentos do bairro Vila Industrial, que se encontra também na faixa de 7,1 a $10 \mathrm{~s} . \mathrm{m}$. A surpresa se fundamenta, pois em observação empírica visualizamos um bairro em condições bastante precárias, com uma população aparentemente carente e com edificações de moradias populares de baixa qualidade. Configurava-se numa paisagem urbana típica da periferia pobre de uma cidade. 

em Rio Claro/SP.

Com relação a Região $\mathbf{2}$ - Nordeste II, nossa análise revelou que a região é formada por 13 bairros, com características bastante diferenciadas. É a região com maior número de habitantes, conta com uma população de 20.767 pessoas. Nessa região se encontra o bairro Vila Alemã, que já em 1940 compunha a área urbana da cidade. Este bairro foi fundado por imigrantes alemães que viviam na cidade, daí seu nome, mas hoje essa presença não é mais sentida e não encontramos qualquer traço cultural ou moradores de origem alemã, permaneceu somente a denominação do bairro. Entretanto, a Vila Martins é exceção, pois a grande maioria dos bairros contidos na região 2 são resultado da grande expansão urbana do período 19671970 e, portanto, caracterizam-se como bairros operários, que foram implantados devido ao grande crescimento populacional da área, resultado da atração causada pela criação do Distrito Industrial da cidade, conforme apresentamos no capítulo 1 desta dissertação. Há nessa região dois bairros que são resultado de loteamentos habitacionais públicos. É O caso do Conjunto Habitacional Arco-Íris, um empreendimento do CECAP (Companhia Estadual de Casas Populares) e do Jardim Bandeirantes que faz parte do programa da COHAB (Companhia Metropolitana de Habitação). Esses dois bairros rompem com a lógica do arruamento em tabuleiro de xadrez, que foi a estrutura de organização adotada pela cidade, o que os tornam diferentes em sua organização territorial. Nessa região encontramos bastante desigualdades nas faixas salariais de rendimentos da população. Destaca-se o bairro Jardim América, onde a população residente possui faixa salarial de 10,1 a 15 s.m.; trata-se de um bairro nobre com normas bastante rígidas para a edificação, o que impossibilitou sua ocupação por uma população com baixos rendimentos. Nos outros bairros predominam as faixas salariais de 3,1 a 5 s.m. e 5,1 a 7 s.m., o que confirma a característica de bairros operários. Na faixa de rendimentos de 7,1 a 10 s.m. encontramos parte da população do bairro Vila Alemã e Vila Nova, e a população do Jardim Village e do Conjunto Residencial Vila Verde, este último foi um loteamento comercializado como conjunto habitacional fechado, o que não se efetivou por questões legais.

Com características bastante semelhantes à região 2, a Região 3 - Norte é composta por 10 bairros que tem em sua área bairros formados, principalmente, no período de 1967-1970, com exceção de parte do bairro Vila Martins, que já era ocupado em 1940. Esta região possui uma população de 14.908 habitantes e contém bairros que foram implantados e direcionados para a classe trabalhadora, 

em Rio Claro/SP.

que não possuía condições financeiras de morar na área central e mais antiga da cidade. Essa região foi pesquisada por Lucca (1981) e se configurava na época da pesquisa como a área com maiores problemas urbanos da cidade. Era uma área bastante degradada, caracterizada pela precariedade das moradias e pela falta de infra-estrutura e serviços urbanos. A região abrigava grande número de migrantes da região Nordeste do país, que vinham para o Sudeste e, especificamente neste caso, para Rio Claro em busca de emprego, o que muitas vezes não acontecia, fazendo com que esta população buscasse formas alternativas para morar e sobreviver. Embora, a região seja formada por diversos bairros, a área é costumeiramente chamada por seus moradores de Jardim Cervezão ou grande Cervezão. O Jardim Cervezão foi o primeiro bairro popular a ser implantado nesta região e conforme a população foi crescendo e os loteamentos aumentaram, o Jardim Cervezão continuou a ser referência de localização desta população, o que criou uma identidade com o lugar, sem levar em consideração os limites impostos pela administração, pelos loteadores; todos viviam no Cervezão. Até hoje essa identidade é preservada com feira-livre semanal, que tem como principal característica à venda de produtos típicos do Nordeste e com festas temáticas.

Diferentemente da realidade analisada por Lucca em 1981, hoje, esta região já recebeu benfeitorias em infra-estrutura e serviços públicos coletivos. Ainda caracteriza-se como bairro operário, porém, agora com menor precariedade urbana e menor índice de violência, problemas estes que migraram para a região 9, como veremos a seguir.

Analisando o mapa de rendimentos encontramos um bairro que se destaca dos demais nesta região, trata-se do Jardim Floridiana, que semelhante ao bairro Jardim América, da região 2, é um bairro nobre. O planejamento municipal inicial para esta área era o de transformar esses dois bairros e adjacências, na área nobre da zona norte da cidade. Porém a grande ocupação popular das áreas vizinhas à esses dois bairros, principalmente, do Jardim Cervezão e entorno, fizeram com que esses dois bairros se desvalorizassem e impossibilitaram a execução do que havia sido planejado. Atualmente, encontramos no Jardim Floridiana população com rendimentos entre 10,1 a 15 s.m., no entanto, à medida que o bairro se aproxima da área do grande Cervezão, a faixa de rendimentos diminui, o que evidencia a desvalorização e a ocupação por uma população com menor poder aquisitivo. A grande maioria da população que vive nessa região tem rendimentos entre 3,1 a 5 

em Rio Claro/SP.

s.m., com exceção da já citada, parte do Jardim Floridiana e parte da Vila Martins, que possuem rendimentos superiores. No entanto, observamos que as áreas que se encontram mais na periferia da área urbana possuem rendimentos bastante baixos, na faixa de 0 a $3 \mathrm{~s} . \mathrm{m}$. Essa localização periférica da população de menor rendimento confirma a existência, no município de Rio Claro, do fenômeno de expulsão da população de baixos rendimentos das áreas centrais e melhor atendidas pela infraestrutura e serviços públicos.

A Região 4 - Leste é bastante próxima à área central e tem uma população de 12.299 habitantes. A presença da Floresta Estadual, nesta região, impossibilitou a expansão urbana da cidade por este caminho e também ajudou a valorizar os bairros próximos a ela. Os loteamentos não são tão recentes, já faziam parte da área urbana da cidade em 1967. O bairro Cidade Nova, mais antigo e que já em 1940 compunha o perímetro urbano, teve sua ocupação caracterizada pela predominância de moradores que eram trabalhadores da Companhia Paulista de Estradas de Ferro, que, posteriormente, se tornou a FEPASA (Ferrovia Paulista S. A.). Esta especificidade na ocupação inicial se deu, pois a área deste bairro é muito próxima a estação ferroviária e a antiga oficina de serviços desta empresa.

Na pesquisa de Lucca (1981), a autora fez uma análise dos classificados dos jornais locais, no período de 1970 a 1980, e constatou que os bairros periféricos destinados à população de menores rendimentos são os que sofriam maior valorização e especulação imobiliária. A autora constatou também que a exceção nesta constatação era o bairro Bela Vista, localizado na região 4, e que no período era o que apresentava maior valorização em toda a cidade. Este fato se deve a implantação do campus da Universidade Estadual Paulista - UNESP, ao bairro, o que trouxe para esta região da cidade uma valorização imobiliária bastante significante. Hoje, essa região, principalmente, os bairros Bela Vista e Vila Bela são ocupados, em grande parte, por estudantes e professores universitários, o que traz para esta área característica de bairro universitário.

Quando analisamos o mapa 3, que apresenta a faixa de rendimentos salariais da população, verificamos que na região predominam os rendimentos que vão de 7,1 a 15 s.m. Os rendimentos só se apresentam inferiores em parte do bairro Vila Paulista e no bairro Jardim Conduta, o último apresentando-se como o mais recente da região e com características ligadas a uma periferia urbana mais carente. Este 

em Rio Claro/SP.

bairro é ocupado por uma população com rendimentos que se encontram na faixa de 3,1 a 5 s.m., o que o diferencia do restante da região.

Todos os 12 bairros que compõem a Região 5 - Sudeste foram implantados entre os anos de 1940 a 1967. Esta região é composta pelos bairros mais nobres da cidade e são ocupados por uma população de altos rendimentos, como podemos verificar no mapa 3, num total de 12.148 habitantes. Os bairros Vila Santo Antônio, Cidade Jardim e Jardim Residencial Copacabana tem uma população que conta com rendimentos elevados, que variam da faixa de 10,1 s.m. a mais de 20 salários mínimos. A área urbana onde se encontram esses bairros é a que atualmente está sendo utilizada para a implantação de condomínios fechados de alto padrão. Não é exagero afirmar que nos últimos seis anos esses condomínios têm se espalhado por toda esta região. Nos mapas apresentados essa expansão de condomínios não aparece, pois se tratam de dados do ano de 2000. Ao sul desta região encontramos bairros com menores rendimentos, mas nunca inferiores a faixa de 5,1 a 7 s.m., como é o caso do Jardim Quitandinha e Bairro do Estádio.

Formada por 13 bairros, dos quais dois foram implantados durante a expansão urbana que aconteceu até 1970 (Chácara Lusa e Jardim Inocoop COHAB) e os demais posteriormente a esta data, a Região 6 - Sul é muito recente e se caracteriza como uma área bastante periférica, distante do centro da cidade. $\mathrm{A}$ região se forma com a transposição de uma barreira, que inicialmente impediu a expansão da cidade, que é a rodovia Washington Luiz. Após a incorporação desta área ao perímetro urbano, ela se expande muito e passa a acompanhar o traçado da rodovia e da estrada que liga as cidades de Rio Claro e Piracicaba. A população que vive nesses bairros é bastante carente e possui rendimentos baixos, concentrandose na faixa que vai de 3,1 a 5 s.m. O bairro Jardim Guanabara se destaca, pois apresenta rendimentos inferiores, na faixa de 0 a 3 s.m., o que se apresenta como insuficiente para suprir as necessidades básicas desta população. A região caracteriza-se pela grande carência econômica; carência de infra-estruturas; saúde e educação. A população desta região, que é de 13.753 habitantes, sofre grande marginalização na sociedade.

Embora, a Região 7 - Sudoeste I, com seus 14 bairros, tenha grande área territorial a população que vive nessa região é de apenas 5.786 habitantes. Parte desta área é ocupada por uma população de médios e altos rendimentos, onde podemos encontrar grandes imóveis com características luxuosas. Observando o 

em Rio Claro/SP.

mapa de rendimentos vemos que os rendimentos desta população se concentram nas faixas salariais que vão de 10,1 a mais de 20 s.m., isto para os bairros que são delimitados pela rodovia Washington Luiz. Aqueles bairros que transpõem a rodovia possuem uma população que têm rendimentos inferiores, concentrados na faixa de 3,1 a 5 s.m., com exceção do bairro Jardim Paulista que mesmo tendo transposto a rodovia manteve uma população com altos rendimentos. Assim como na região 6 , os bairros da região 7, que transpuseram a rodovia, são bairros mais recentes que abrigam uma população mais carente que não teve condições financeiras de se manter nas áreas mais centrais e nas áreas com maior investimentos públicos. Observamos que a distância e a dificuldade de acesso são decisivas para que ocorra a ocupação pela população mais carente. Esta população sofre com problemas de mobilidade urbana, pois embora haja transporte coletivo público nesta área, muitas vezes, não há condição financeira para que eles se locomovam.

Os loteamentos e empreendimentos imobiliários que transpuseram a rodovia Washington Luiz, tanto na região 6 e 7, como na região 17, que veremos adiante, são caracterizados pela total falta de planejamento urbano, infra-estrutura e serviços públicos. Eles foram implantados, em grande parte dos casos, para beneficiar proprietários que tinham suas terras na zona rural e que, com o aumento do perímetro urbano e autorização para implantação de loteamentos, passam a obter grandes benefícios com a renda da terra e a especulação imobiliária. Em contrapartida, a população que vai viver nessas áreas, por falta de opção, sofre com o distanciamento do centro, com a necessidade de travessia da rodovia e com a precariedade da área onde moram.

Com população de 13.711 habitantes a Região 8 - Oeste, composta por 11 bairros, é resultado da expansão urbana que aconteceu até 1970, resultado da instalação de indústrias na cidade, da mecanização do campo e das migrações intraurbanas, que são grandes contribuintes para o crescimento populacional e da cidade.

A região 8 é uma região bastante pobre, bastante populosa e que apresenta grandes problemas de infra-estrutura, saúde e educação. O rendimento da população fica entre as faixas de 3,1 a 5 s.m. e 5,1 a 7 s.m. O Jardim Wenzel é o que apresenta maior rendimento da população entre 7,1 a $10 \mathrm{s.m}$. Já os bairros Jardim Panorama e Jardim Paineiras apresentam os menores rendimentos, a população sobrevive com salários de 0 a 3 s.m. 

em Rio Claro/SP.

A Região 9 - Noroeste é uma das regiões mais carentes e pobres da cidade. Composta por 10 bairros e com uma população de 14.270 habitantes, ela é formada por loteamentos bastante recentes, onde muitos deles são irregulares e/ou foram ocupados. Contíguo a região 3 , os bairros pertencentes a região 9 são resultado do grande crescimento populacional do chamado grande Cervezão, que extrapolou os limites dessa região e passou a ocupar novas áreas. É resultado também das benfeitorias recebidas na região 3 , que expulsou moradores que não podiam pagar por água encanada, energia elétrica regular e IPTU, ou, viram na venda de sua propriedade, mais valorizada pela implantação desses benefícios, a oportunidade de solucionar problemas financeiros que enfrentavam. Com exceção dos moradores dos bairros Jardim Azul e Jardim Santa Maria, que tem seus rendimentos entre 3,1 a 5 s.m., toda a população da região tem rendimentos baixíssimos na faixa de 0 a 3 s.m. São bairros que foram ocupados sem a menor preparação, ou seja, sem asfaltamento, rede de esgoto, rede de águas pluviais, iluminação, escola e postos de saúde. Embora, nos últimos anos as condições de vida dessas pessoas tenham melhorado, elas ainda sofrem com a falta de empregos, distância do centro e a crescente violência, ligada, principalmente, ao tráfico de drogas.

A Região 10 - Centro I tem localização central, mas não comporta o centro mais antigo da cidade. Esta região é formada por 12 bairros e tem o número populacional bastante alto, 19.975 habitantes. Os bairros Santana, Santa Cruz, Vila Saibreiro e Vila Aparecida são os mais antigos da região, sendo que, o Santana abriga o mais antigo campus da Universidade Estadual Paulista - UNESP (o mais novo fica na região 4, bairro Bela Vista). O restante dos bairros que formam a região, já em 1967, fazia parte da área urbana. Estes bairros seguem o ordenamento da cidade, que possui arruamento em tabuleiro de xadrez. Eles também se caracterizam pela população de classe média com rendimentos que variam de 5,1 a 15 s.m. Esta região conta com toda sorte de infra-estrutura urbana, além de serviços de educação, saúde e cultura.

Na Região 11 - Centro II encontra-se a área urbana mais antiga da cidade, que já estava consolidada em 1893. É a área onde foi fundada a cidade e onde se pode encontrar toda variedade de comércio e serviços. Nesta região encontra-se a Santa Casa, a antiga estação ferroviária, a Prefeitura, o Fórum, etc. Além da zona central, encontramos outros 8 bairros que compõem a região, juntos eles têm uma população de 15.642 habitantes. Esta população tem seus rendimentos 

em Rio Claro/SP.

predominantemente na faixa de 10,1 a 15 s.m. No entanto, podemos encontrar alguns setores censitários da região com rendimentos superiores, na faixa de 15,1 a 20 s.m., e também rendimentos inferiores que se encontram na faixa de 7 a 3,1 s.m.

A região mais nova do orçamento participativo de Rio Claro, que foi formada em 2004, pelo desmembramento da região 7, após reivindicação dos moradores, é a Região 17 - Sudoeste II. Embora essa região tenha um pequeno território, ela é formada por apenas dois bairros, e tenha uma população de 3.246 habitantes, ela se configura como a mais carente da cidade. A criação destes dois bairros é recente, eles foram implantados próximos ao rio Corumbataí, o que traz sérios problemas à população, pois legalmente a área não poderia ser ocupada por se tratar de área ciliar e inundável. Os moradores desta região sofrem com infiltrações em suas casas e grande umidade, o que provoca doenças respiratórias, principalmente, nas crianças e idosos. E, também, pela impossibilidade de construir em algumas áreas, que foram loteadas e comercializadas, pelo fato delas se configurarem em minas d'água.

A região também foi formada com a transposição da rodovia Washington Luiz, mas, ao contrário de outros bairros não se localiza à margem da rodovia, se distancia ainda mais da área central. Os moradores ocupam ilegalmente as áreas do bairro ou compram lotes, mas não têm a escritura da propriedade, já que os bairros não estão legalizados. Há grande presença de população que migrou do Nordeste do Brasil. $O$ rendimento de todos os moradores se fixa na faixa salarial de 0 a $3 \mathrm{~s} . \mathrm{m}$. Há grande demanda por infra-estrutura e serviços públicos, como saúde e educação. $O$ desemprego e a falta de qualificação dificulta a sobrevivência da população desta região, que se mantém graças a assistência pública e religiosa. A imobilidade também agrava a situação desta população, que, muitas vezes, não tem condições financeiras de utilizar o transporte público e acaba se locomovendo, por grandes distâncias, a pé ou de bicicleta.

\section{Debate sobre as Divisões Territoriais no OP}

No livro "Mudar a Cidade: uma introdução crítica ao planejamento e a gestão " Souza (2002) , a grande preocupação geográfica apresentada, além da questão de gestão e planejamento, como veremos adiante, quando se discute o processo do orçamento participativo é a questão da divisão espacial que se estabelece nos municípios, quando da implementação desse instrumento. A divisão espacial se 

em Rio Claro/SP.

realiza devido a necessidade da descentralização, importante para a implementação de um processo que discute a distribuição de verbas e de obras e serviços num espaço complexo e fisicamente grande como a cidade. $O$ autor coloca que:

\begin{abstract}
Essa divisão deve levar em conta, com muita atenção, os quadros de referência quotidianos de orientação e organização da própria população... não deve se restringir a considerar diferenças e semelhanças "objetivas", como a distribuição espacial da renda. É necessário, acima de tudo, incorporar as identidades sócio-espaciais (identidades de bairros) e as tradições da população local, ou seja, aquilo que é expresso pelos conteúdos interacional e simbólico. (SOUZA, 2002 p.354)
\end{abstract}

A preocupação espacial colocada refere-se a dimensão espacial, ou seja, com a divisão do espaço urbano em unidades espaciais, ou, como ficou conhecida em quase todas as experiências do OP, em regiões. É através dessa divisão que se estabelecem os lugares $\mathrm{e}$ as dimensões onde serão discutidas e realizadas as reuniões do OP. A utilização dos bairros, como unidades espaciais, no município de Rio Claro/SP e, também em outros municípios, se mostrou inadequada devido ao grande número de bairros das cidades e ao grande número de demandas que se apresentavam.

A preocupação com a divisão da cidade em regiões, embora seja importante, pois não se deve romper com as identidades da população com o lugar, nos parece secundária. Principalmente, quando se trabalha com um processo onde 0 conhecimento popular, o conhecimento do lugar é o principal elemento para discussão. Pois, embora uma divisão estritamente técnica e equivocada possa prejudicar inicialmente o desenvolvimento do processo e de seus resultados, isto não impede que após serem identificados os equívocos na divisão espacial, estes sejam corrigidos. Acreditamos até que essa discussão posterior com a população, após se ter vivenciado o processo e estabelecido o contato com as etapas do OP, pode enriquecer o debate e tornar a divisão espacial mais real e sólida, pois ela trará um acúmulo de conhecimento técnico e popular.

A discussão espacial nos processos do OP vai muito além desse problema, ela a ultrapassa. A discussão espacial contida no processo e que, neste trabalho consideramos mais importante, diz respeito à revelação, segundo a qual as demandas apresentadas durante as reuniões regionais dão ao espaço geográfico da cidade; elas revelam a fragmentação desse espaço que é fruto da mercantilização do solo urbano, dos investimentos em infra-estrutura e serviços não-igualitários 
praticados pela administração pública, que dentro da lógica do capital, investe em áreas que são de alto interesse imobiliário, em detrimento das áreas populares e da periferia onde estão alojadas a população de baixa renda que foram expulsas do centro urbano e da vida urbana, por essa mesma lógica.

A preocupação com a territorialização e a divisão do território para discussão do OP é importante, mas secundária, porque quando acompanhamos as reuniões constantemente vemos que essa preocupação se adequa e se resolve, conjuntamente entre administração e população, com o tempo. Inicialmente, a divisão pode não contemplar e agradar todos os moradores das regiões, mas isso rapidamente é levantado pela população e o rearranjo da região é discutido criandose uma nova região, desmembrando outras, redistribuindo os bairros, etc.

Ainda sobre a divisão espacial do município, temos uma posição contrária ao colocada por Souza (2002), no que diz respeito ao agrupamento de diferentes realidades sociais num mesmo espaço, pois para o autor:

Se a divisão espacial for inadequada, realidades com grandes afinidades entre si, não somente em matéria de conteúdo composicional, mas também de conteúdo interacional e simbólico, poderão ser separadas artificialmente, ou, no caso inverso, realidades sócio-espaciais com pouca afinidade poderão ser artificialmente agrupadas, gerando incompatibilidades e atritos.(SOUZA, 2002, p. 356)

Ora, conforme analisamos e vivenciamos, na experiência de Rio Claro/SP, o trabalho em regiões que apresentavam diferenças sociais e econômicas foi de demasiada importância para o enriquecimento do processo, pois as regiões que misturam as diferentes realidades econômicas e sociais apresentaram debates interessantes e muito ricos, onde pontos de vista opostos eram defendidos e após muito tempo de debate, exposição dos problemas vivenciados e convites para que o outro conhecesse de perto sua realidade, sempre se chegava a um consenso sobre o que se apresentava mais emergencial e prioritário, decidindo-se assim o que deveria entrar no orçamento final. Esse tipo de experiência permite que a população que vive em determinado bairro e não interage ou simplesmente não conhece seus bairros vizinhos, possam passar a ter um conhecimento maior sobre a realidade da sua região, do seu entorno e até mesmo da sua cidade, permitindo, dessa forma, um maior conhecimento, uma maior apropriação do espaço. Se trabalharmos com a afirmativa de Souza (2002), estaremos não só reforçando a questão da 
fragmentação do espaço, como também a segmentação de setores sociais que não dialogam entre si, mas somente dialogam entre seus iguais.

Em nosso entendimento outra questão importante, referente ao OP e a questão espacial é a inversão de prioridades possibilitada por esse instrumento.

O sentido da inversão de prioridades é canalizar recursos públicos para aquelas áreas que pela dinâmica de produção das cidades são tradicionalmente excluídas da atenção do poder público, as áreas caracterizadas como concentradoras de 'pobreza urbana'. (ALFONSIN \& MOTTA, 2005).

Esta é uma potencialidade do processo do OP, à medida que são as regiões mais carentes e com maior demanda por infra-estrutura e serviços que participam do processo e reivindicam melhorias para a sua região. Dessa forma, o OP permite a mudança da lógica de privilégios praticada por administrações municipais, que priorizam as áreas centrais para seus investimentos.

Acreditamos que processos, como o OP, também devem apresentar uma outra perspectiva relacionada à reversão da pobreza e que devem trabalhar para o fortalecimento dos sujeitos coletivos da população, na economia urbana, através de implantação de projetos de economia solidária, por exemplo. Devem ser projetos que visem à auto-sustentação em longo prazo e a emancipação da condição de pobreza absoluta, sem que o Estado aja de maneira paternalista constantemente. 


\section{Funcionamento do Orçamento Participativo em Rio Claro}

Organograma do Funcionamento do Processo do Orçamento Participativo - Rio Claro/SP.

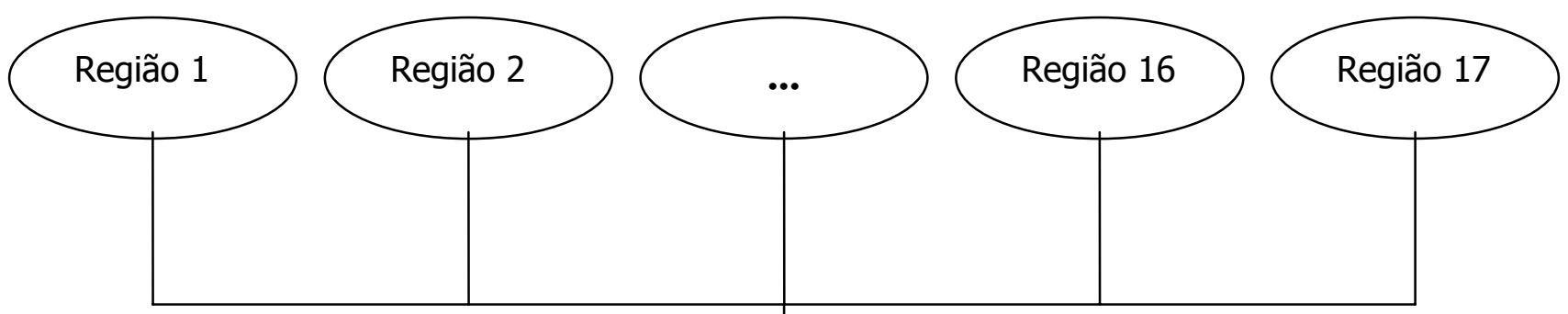

17 Reuniões regionais - indicação de 3 prioridades por pairro e, escolha do representante e suplente do bairro

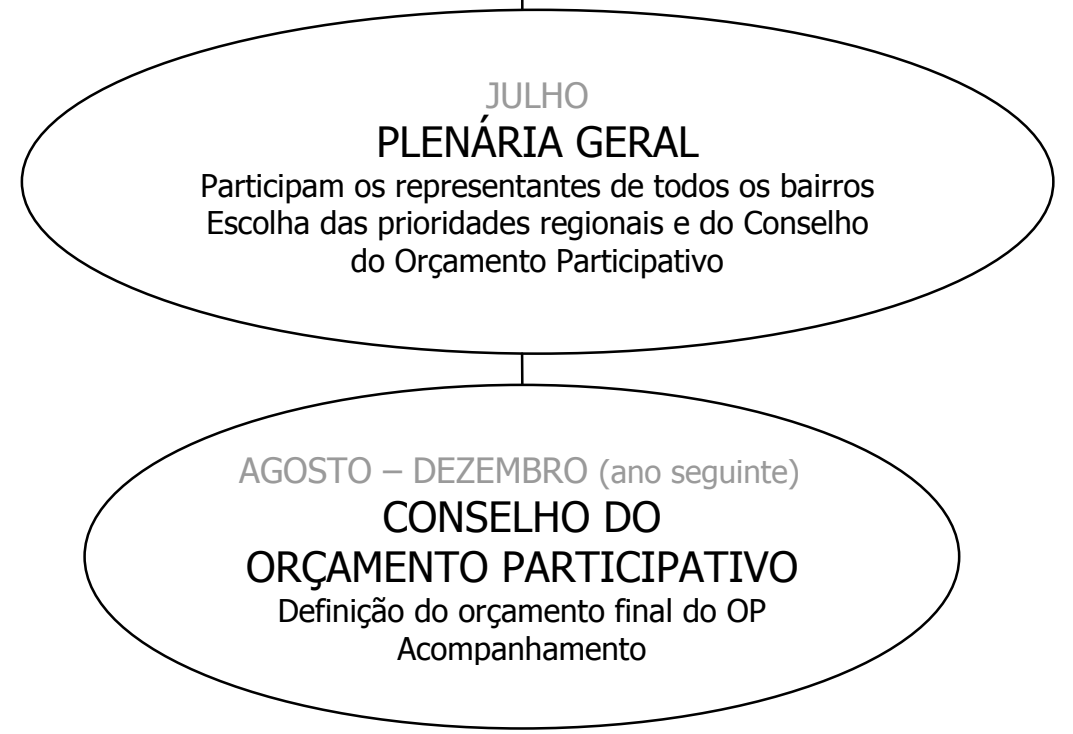

O primeiro passo para organização do OP, no município de Rio Claro/SP foi montar o calendário de reuniões para poder iniciar a divulgação do processo em todas as regiões do município. A divulgação das reuniões é fundamental para a difusão e o bom funcionamento do processo e ela deve ser realizada através de diferentes mídias. Em Rio Claro/SP, ela foi feita através de outdoors espalhados pela cidade, propaganda em jornais de circulação local, emissoras de rádio e televisão local, aviso em diversos eventos que reúnem pessoas da comunidade em geral e a distribuição de um folheto específico do OP, que contêm a divisão regional dos bairros, a data, local e horário das reuniões e uma breve explicação sobre o processo. Essa distribuição foi realizada em todas as residências, alguns dias antes da reunião regional de cada bairro.

As reuniões regionais aconteceram uma vez por ano em cada uma das 17 regiões e nelas os moradores dos bairros assistiam a uma apresentação do 
funcionamento do Orçamento Participativo e também informações sobre o funcionamento interno da prefeitura municipal, além da apresentação sobre as obras realizadas e em andamento na região. Após essa explicação, sempre realizada por um técnico da Prefeitura, os moradores são agrupados de acordo com os bairros de residência, e discutiam entre si as demandas de investimentos de seu bairro. Nessa oportunidade também escolhiam um representante e um suplente que representaria o bairro na Plenária Geral (sempre ocorrida no mês de julho de cada ano).

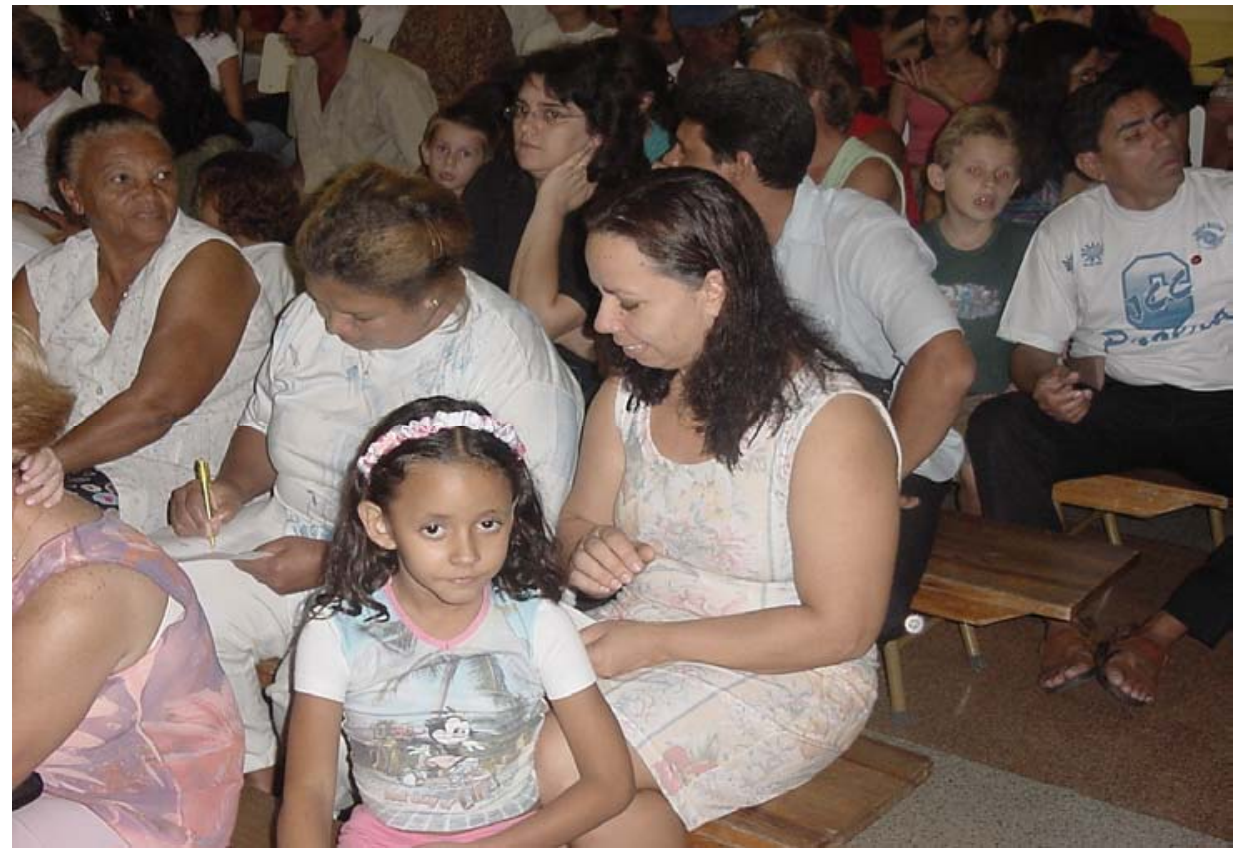

Fonte: Assessoria de Imprensa, Prefeitura Municipal de Rio Claro, 2004.

As prioridades eleitas por todos os bairros eram encaminhadas para os técnicos da Prefeitura, responsáveis por cada assunto levantado, para que eles pudessem analisar a viabilidade e possibilidade de realização dos pedidos. Essa etapa de análise, por parte dos técnicos, é necessária, porque muitas vezes os cidadãos fazem pedidos que são tecnicamente inviáveis como, por exemplo, construção de pronto-atendimento hospitalar, que funcione $24 \mathrm{hs}$, em bairro onde, ao lado, o bairro vizinho já possui o serviço, ou então obras que possuem valor muito alto e que a verba destinada ao OP não seria suficiente para realizá-la.

Após a realização dessa análise pelos técnicos, realizava-se a Plenária Geral, que acontecia, geralmente, em uma noite de julho e onde todos os representantes de bairros, eleitos nas reuniões regionais, eram chamados para conhecer a análise feita pelos técnicos e para juntos discutirem quais seriam as 3 principais prioridades da região e eleger o Conselho do Orçamento Participativo. Os técnicos que realizavam uma espécie de "filtragem" das prioridades dos bairros, apresentavam a 
viabilidade e o custo das solicitações. Nessa fase é bastante interessante observar a discussão entre os representantes dos bairros, porque eles conhecem mais profundamente as necessidades dos bairros e precisam decidir quais são as fundamentais para a região. Muitas vezes, o cidadão percebe que a prioridade do bairro vizinho é mais urgente ou mais importante e "abre mão" de sua demanda, para que outra possa ser atendida.

Era na Plenária Geral também, que acontecia a escolha do Conselho do Orçamento Participativo (COP). Os conselheiros do OP eram escolhidos entre os representantes de bairros de cada uma das regiões, sendo que, cada região indicava um conselheiro e um suplente. A partir dessa escolha, os representantes de bairro acompanhavam a evolução das ações do OP, entrando em contato com o conselheiro de sua região. Além dos 17 conselheiros regionais o COP também era formado por mais 4 conselheiros que eram indicados pela administração municipal, referente a representantes da Secretaria de Obras, Secretaria de Justiça e Governo, Secretaria de Finanças e Secretaria de Desenvolvimento, Planejamento e Meio Ambiente, que era a Secretaria coordenadora do OP.

$O$ trabalho realizado pelo COP é fundamental para o pleno desenvolvimento do OP, porque o conselho, num primeiro momento, discute a distribuição da verba destinada ao processo, dentre as prioridades que foram eleitas em cada região. A etapa de destinação de verbas para as prioridades é bastante delicada, pois os conselheiros recebiam um orçamento de cada uma das obras e serviços solicitados e tinham que decidir como seria a distribuição do orçamento. O que ocorria, comumente, era que o orçamento destinado ao OP acabava sendo suficiente para realizar apenas uma obra por região o que, muitas vezes, podia frustrar os participantes, que não viam sua reivindicação realizada.

Os conselheiros do OP discutiam apenas uma pequena porcentagem da parcela de investimentos do município, os conselheiros decidiam a implantação de $2 \%$ do orçamento geral, já que o restante das verbas estavam comprometidas e eram ainda decididas pelo prefeito e seus assessores. Os cidadãos que participavam apenas como simples reivindicadores não alcançavam seu objetivo, que é a resolução de seu problema, podendo abandonar o processo. Porém, com a participação na totalidade do processo fica, para o cidadão, o conhecimento sobre a cidade, a administração municipal, o funcionamento do orçamento municipal e, tudo que a realização de uma obra significa, como por exemplo, a manutenção constante 

em Rio Claro/SP.

e contratação de pessoal para tanto. Essas informações sobre o funcionamento da administração municipal eram apresentadas já nas reuniões regionais, quando se realizava uma comparação do orçamento municipal ao orçamento familiar, para que a população tivesse maior proximidade com o tema. Porém, os conselheiros tinham um maior aprofundamento dessas questões, à medida que iriam entrar em contato com o tema por mais tempo.

Para que os conselheiros tivessem maior propriedade na decisão era realizada todo ano a Caravana do OP. Este era um momento bastante importante do processo, pois todos os conselheiros tomavam contato com a realidade das outras regiões da cidade, já que, muitas vezes, eles conheciam apenas sua região e a região central da cidade. A Caravana do OP acontecia em um sábado, costumeiramente, e o prefeito, juntamente com todos os conselheiros do orçamento participativo, fazia um trajeto por todas as prioridades elencadas nas reuniões regionais do OP. Durante o percurso o prefeito municipal mostrava investimentos que estavam sendo realizados na cidade e discutia as possibilidades ou impossibilidades de execução das obras demandas no OP. Esta atividade permitia uma maior apreensão da cidade e de suas diferentes realidades. Ficavam evidentes as desigualdades espaciais existentes em Rio Claro e as carências emergenciais vividas por alguns bairros. Este momento permitia uma maior sensibilização dos conselheiros com os problemas vividos por alguns moradores da cidade.

Após a caravana, a discussão e a distribuição da verba destinada ao OP, era preparado um documento onde eram apresentados as prioridades do OP e o orçamento para realização dessas reivindicações. Esta documentação era entregue ao Departamento de Contabilidade da Prefeitura, para que o departamento agregasse ao orçamento geral do município. A chamada, peça orçamentária da Prefeitura deve ser entregue até o dia 30 de setembro para a Câmara de Vereadores, conforme determina a legislação e, neste momento sempre estavam presentes os membros do COP, para que fosse reforçada, junto ao Poder Legislativo, a contribuição dos cidadãos na formulação de parte do orçamento municipal.

Durante os meses de outubro a dezembro o COP havia interrupção de suas atividades, porque nesse período a Câmara Municipal de Vereadores estuda e analisa o orçamento para realização de emendas que julgarem necessárias. 0 Orçamento Municipal deve ser aprovado até o dia 31 de dezembro para vigorar a 
partir de $1^{\circ}$ de janeiro. É a partir dessa data que o Conselho do Orçamento Participativo passava a exercer a sua função de acompanhamento e fiscalização das prioridades que foram selecionadas para serem executadas. Esse acompanhamento era feito através de reuniões mensais, que reunia os membros do Conselho e representantes da administração municipal, que iriam transmitir as informações das prioridades e prestar contas do que estava sendo realizado. Muitas vezes, durante a execução do orçamento, problemas de várias ordens eram enfrentados, como a paralisação de processos devido a questionamentos na licitação, arrecadação de impostos menores do que o esperado, embargo de obras, etc. Todas essas questões deviam ser repassadas e bem discutidas com o Conselho para que seus membros soubessem quais eram os obstáculos que tinham que ser enfrentados para o pleno funcionamento da chamada "máquina" administrativa e também para tivessem conhecimento dos limites do processo.

O controle social por parte do cidadão, uma vez aprovado o orçamento, aparece como elemento central para a conservação da legitimidade do processo e a garantia de sua transparência. O Conselho do Orçamento Participativo podia ter um real poder de decisão, mas ele era limitado a decisão sobre uma pequena parte do orçamento. Além desta limitação dada ao conselho do orçamento participativo Souza (2002, p. 387) apresenta alguns outros problemas enfrentados na implantação do OP, sendo eles:

os Boicotes patronais,

os Escassez de recursos devido ao desperdício,

cos Incompetência gerencial (tributos municipais mal utilizados),

os Corrupções de administrações anteriores,

os Conflitos ideológicos entre grupos específicos dentro da administração (tendências políticas diferentes), o que paralisa ou compromete algumas atividades,

os Resistência corporativista e tecnocrática dos detentores do saber técnico em aceitar a colaborar com os esquemas de participação popular.

Essas questões apresentadas pelo autor são de difícil solução e geralmente requer soluções políticas, o que envolve muito mais negociação do que mobilização de conhecimentos.

No OP de Rio Claro/SP podemos destacar, como um dos principais problemas, não só em sua implementação, mas também durante todo seu 
desenvolvimento, a corrupção em administrações anteriores, o que comprometeu enormemente o orçamento municipal, pois devido a empréstimos feitos em dólares, em administrações anteriores, o município sofre com a necessidade do pagamento e amortização dessas dívidas, que oscilam devido à variação cambial, prejudicando a execução orçamentária geral e, principalmente, os investimentos municipais.

O outro problema enfrentado e o mais preocupante do nosso ponto de vista está ligado a resistência dos funcionários públicos, que são detentores do saber técnico estarem colaborando junto aos processos de participação popular. Há uma idéia difundida entre grande parte dos técnicos da Prefeitura, que acreditam que a população não tem nada a acrescentar nos debates $e$ decisões sobre implementação de obras e serviços na cidade, pois estes não possuem um saber técnico-científico. Há também uma preguiça em debater aquilo que antes era decidido facilmente em gabinete, pois os processos de participação popular demandam muito trabalho no sentido de explicar, fazer-se entender e também se apropriar das idéias e debates que são realizados em campo, diretamente com a população. No caso de Rio Claro/SP foram raros os casos de técnicos que se incorporaram ao OP e compreenderam sua importância, no entanto, também há casos emblemáticos de participação ativa de técnicos que acreditaram no processo e estabeleceram um debate rico e proveitoso, não só relacionado ao $\mathrm{OP}$, mas também a outras atividades das diferentes secretarias. Podemos destacar o trabalho realizado na Secretaria de Ação Social, onde um assistente social, apoiado pela secretária municipal e a Secretaria de Obras e Serviços, onde um tecnólogo realizou um difícil trabalho de aproximação dessa secretaria ao OP, visto que o secretário municipal apresentava uma resistência ao processo e que a Secretaria de Obras e Serviços era chave fundamental para o processo, pois é esta secretaria que executa as obras municipais.

\section{Perfil dos Participantes das Reuniões do OP}

Após a análise realizada dos três mapas da cidade de Claro - Divisão Regional do OP, Expansão Urbana e Rendimentos da População - obtivemos uma caracterização geral do espaço urbano da cidade de Rio Claro e percebemos que este espaço que é produto, condição e meio das relações sociais foi produzido e apropriado de maneira desigual, resultado da reprodução do modo de produção 
capitalista. Até mesmo sem observar a paisagem urbana podemos concluir que a desigualdade social e espacial é presente em todo o espaço da cidade.

Há regiões que se destacam pelo alto nível de rendimentos da população que as ocupa, caso das regiões 5 e 11. Estas regiões também são marcadas pela data de implantação de seus loteamentos, que já estavam consolidados antes de 1970 e que já possuem toda a infra-estrutura, serviços, comércios e serviços públicos, necessários para a reprodução da vida. Já em regiões como a 9 e 17, o destaque fica pela sua recente ocupação, em áreas mais distantes do centro da cidade, pelas precárias condições de vida no lugar, onde não há o mínimo de infra-estrutura e serviços públicos que são básicos para a reprodução da vida. É característica destas regiões também os baixos níveis de rendimentos da população, que vive com um mínimo de recursos e, muitas vezes, dependendo totalmente da assistência pública elou filantrópica.

Analisando resumidamente a situação dessas 4 regiões e observando de maneira mais detalhada a análise que foi realizada anteriormente, das 12 regiões do $\mathrm{OP}$, que estão dentro da área urbana, encontramos a produção desigual do espaço e a contrariedade vivida cotidianamente por estas pessoas. A população que mora na cidade vivencia as desigualdades e vive a contrariedade produzida pela apropriação privada da terra, onde nem todos têm acesso a terra e, por isso é necessário encontrar alternativas para viver e sobreviver na cidade. É a população urbana que vivencia a cidade e vive a realidade urbana, que tem como característica sobressalente a carência. Em menor e maior intensidade, com apreensões distintas, a população enfrenta os problemas urbanos que são problemas da vida cotidiana.

A vivência desta população, principalmente, da que vive com baixos rendimentos em áreas periféricas irá nos revelar a crise da cidade, a desordem e o caos de onde vivem. Esta crise e desordem vão se revelar mais veementemente quando analisamos os resultados do orçamento participativo, que traz a manifestação da população que vive o caos. Esta população até então não se manifestava, pois não há entre eles mobilização e movimento social. O OP, que é proposto por gestões municipais de esquerda, ou com tendência à esquerda, e que praticam uma gestão mais próxima da população, compartilham com a população a gestão da cidade, mas principalmente, a gestão daquilo que aparece com maior destaque na cidade, que é a carência. 
Esta dissertação apresenta a análise da experiência de implementação do OP, na cidade de Rio Claro. Para conhecermos melhor e traçarmos um perfil das pessoas que se dispõe a participar das reuniões regionais do orçamento participativo aplicamos um questionário aos participantes, durante as reuniões que aconteceram no ano de 2004. O questionário foi distribuído juntamente com os formulários de credenciamento da população.

É válido lembrar que em algumas regiões algumas pessoas preferiram não responder esse questionário e não preencher o formulário de inscrição, o que não torna absoluto os números de participantes e também pode trazer certa imprecisão quanto ao perfil destes. Porém, as pessoas que não preencheram o questionário são minoria, pois a maioria das pessoas preencheu o formulário e responderam o questionário, o que nos permite trabalhar com os dados que possuímos e apresentar uma análise bastante aproximada da realidade.

O questionário aplicado continha perguntas referentes a dados pessoais: idade, sexo, escolaridade. Inserimos também questões que tinham por objetivo tentar identificar se as pessoas que participavam do processo do OP tinham um histórico de militância e participação em movimentos sociais. Para isso perguntamos se já haviam participado de outras reuniões do OP e se faziam parte de alguma associação, partidos políticos, conselhos municipais, entre outros.

O resultado obtido na tabulação dos 610 questionários nos apresentou a seguinte situação. 

em Rio Claro/SP.

Tabela 1 - Faixa Etária dos participantes das Reuniões Regionais do OP 2004 (\%)

\begin{tabular}{|c|c|c|c|c|c|c|c|c|}
\hline $\begin{array}{c}\text { Região/ } \\
\text { Fx. } \\
\text { Etária }\end{array}$ & $\begin{array}{c}\text { Menores } \\
\text { de } \mathbf{2 0}\end{array}$ & $\mathbf{2 0 - 2 9}$ & $\mathbf{3 0 - 3 9}$ & $\mathbf{4 0 - 4 9}$ & $\mathbf{5 0 - 5 9}$ & $\begin{array}{c}\mathbf{6 0} \text { ou } \\
\text { mais }\end{array}$ & $\begin{array}{c}\text { Não } \\
\text { respondeu }\end{array}$ & Total \\
\hline $\mathbf{0 1}$ & zero & 11 & 12 & 27 & 27 & 23 & zero & 100 \\
\hline $\mathbf{0 2}$ & 3 & 21 & 14 & 35 & 12 & 15 & zero & 100 \\
\hline $\mathbf{0 3}$ & 7 & 23 & 27 & 27 & 13 & 3 & zero & 100 \\
\hline $\mathbf{0 4}$ & 2 & 21 & 25 & 30 & 9 & 9 & 4,5 & 100 \\
\hline $\mathbf{0 5}$ & 3 & 21 & 34 & 26 & 11 & 5 & zero & 100 \\
\hline $\mathbf{0 6}$ & 14 & 23 & 21 & 26 & 7 & 8 & 1 & 100 \\
\hline $\mathbf{0 7}$ & zero & 11 & 31 & 27 & 23 & 8 & zero & 100 \\
\hline $\mathbf{0 8}$ & 2 & 16 & 29 & 25 & 18 & 5 & 5 & 100 \\
\hline $\mathbf{0 9}$ & 8 & 18 & 35 & 19 & 16 & 4 & zero & 100 \\
\hline $\mathbf{1 0}$ & 7 & 10 & 14 & 28 & 10 & 31 & zero & 100 \\
\hline $\mathbf{1 1}$ & zero & 21 & 42 & 16 & 5 & 16 & zero & 100 \\
\hline $\mathbf{1 2}$ & zero & 15 & 31 & 31 & 15 & 8 & zero & 100 \\
\hline $\mathbf{1 3}$ & 10 & 25 & 35 & 15 & 5 & 10 & zero & 100 \\
\hline $\mathbf{1 4}$ & zero & 33,3 & 33,3 & zero & zero & 33,3 & zero & 100 \\
\hline $\mathbf{1 5}$ & 15 & 8 & 39 & 15 & 8 & 15 & zero & 100 \\
\hline $\mathbf{1 6}$ & zero & zero & zero & zero & 100 & zero & zero & 100 \\
\hline $\mathbf{1 7}$ & 16 & 27 & 22 & 13 & 11 & 11 & zero & 100 \\
\hline
\end{tabular}

Com referência a faixa etária dos participantes, notamos que houve uma grande concentração de participantes de idades entre 30 a 49 anos, isto é notado em todas as regiões. Há regiões com a maior parte de seus participantes entre outras faixas etárias, caso da região 17 , onde encontramos uma participação um pouco mais jovem com $27 \%$ dos participantes com idade entre 20 a 29 anos, o que mostra que nesta região houve uma maior participação jovem. Este fato pode estar ligado a recente ocupação da região, onde muitos moradores são jovens nordestinos que vêm para o Sudeste em busca de melhores condições de vida e também jovens famílias que estão se formando e encontram na periferia o lugar possível para se instalarem. A região 14 apresenta uma divisão de seus participantes igualmente distribuídos entre 20-29; 30-39 e 60 anos ou mais. Na região 16 todos os participantes se encontram na faixa etária de 50 a 59 anos. A maior idade dos participantes pode ser explicada porque esta região se trata de uma vila rural onde não há grandes oportunidades de emprego e educação, o que obriga a população mais jovem a se deslocar e até mesmo se mudar do local para encontrar trabalho.

Notamos que a presença do jovem ainda é bastante reduzida, já que obtivemos um pequeno número de pessoas com idade inferior a 20 anos e na faixa etária de 20 a 29 anos existe uma maior participação somente na região 17, como já citamos, e na região 14 , que pode ser explicada pelo convite feito aos amigos do 
sub-prefeito deste distrito que é jovem e trouxe para a reunião do OP pessoas de sua idade. A falta da participação jovem, nas outras regiões, pode ser explicada pela falta de trabalho de mobilização direcionada a este grupo, que poderia acontecer junto às escolas, grêmios estudantis e outros lugares de concentração juvenil e também pela desmotivação que os jovens têm em comparecer a discussões sobre a política da cidade. Ao contrário, a população idosa, apesar de não ser maioria em nenhuma região apresenta um número razoável de participantes em diversas reuniões. Somente a região 16 não apresentou nenhuma pessoa com 60 anos ou mais em sua reunião, o que demonstra que as pessoas de mais idade têm disposição a contribuir para a discussão da cidade e seus problemas.

A Tabela 2 evidencia o gênero que mais participa do processo de discussão democrática do orçamento municipal. Observamos que a grande maioria dos participantes são as mulheres. Em 13, das 17 regiões da cidade, elas representam a maioria ou metade dos participantes. Em números absolutos das 605 pessoas que, participaram das 17 reuniões regionais e responderam ao questionário, as mulheres representam 367 mulheres, ou seja, 61\% dos participantes. Esta maior participação das mulheres está relacionada com o cotidiano delas, pois de maneira geral são as mulheres que levam os filhos as unidades básicas de saúde, acompanham a vida escolar das crianças e estão mais presentes na vida da comunidade. As mulheres têm maior contato com os problemas enfrentados cotidianamente e, com a emancipação feminina, elas vão a público lutar e reivindicar por melhores condições de vida na cidade. 
Tabela 2 - Distribuição por sexo dos participantes das Reuniões Regionais do OP 2004 (\%)

\begin{tabular}{|c|c|c|c|}
\hline Região & Feminino & Masculino & Não respondeu \\
\hline $\mathbf{0 1}$ & 58 & 38 & 4 \\
\hline $\mathbf{0 2}$ & 47 & 50 & 3 \\
\hline $\mathbf{0 3}$ & 83 & 14 & 3 \\
\hline $\mathbf{0 4}$ & 55 & 43 & 2 \\
\hline $\mathbf{0 5}$ & 77 & 23 & zero \\
\hline $\mathbf{0 6}$ & 60 & 39 & zero \\
\hline $\mathbf{0 7}$ & 35 & 65 & 2 \\
\hline $\mathbf{0 8}$ & 60 & 38 & 2 \\
\hline $\mathbf{0 9}$ & 65 & 33 & zero \\
\hline $\mathbf{1 0}$ & 59 & 41 & 5 \\
\hline $\mathbf{1 1}$ & 63 & 32 & zero \\
\hline $\mathbf{1 2}$ & 62 & 23 & zero \\
\hline $\mathbf{1 3}$ & 50 & 50 & zero \\
\hline $\mathbf{1 4}$ & 17 & 83 & zero \\
\hline $\mathbf{1 5}$ & 85 & 15 & zero \\
\hline $\mathbf{1 6}$ & 50 & 50 & \\
\hline $\mathbf{1 7}$ & 44 & 56 & \\
\hline
\end{tabular}

Quando questionado sobre a escolaridade da população que participou da formulação do Orçamento Participativo 2004, constatou-se que a maioria dos participantes concentrava-se nas categorias que tinha cursado o Ensino Fundamental Incompleto e Ensino Médio Completo (tabela 3). A participação de pessoas com o Ensino Fundamental Completo também é grande, principalmente, nas regiões 11 (Centro 2), região 13 (Distrito de Ajapi) e região 14 (Distrito de Ferraz). As regiões 4 (Leste) e 10 (Centro 1) destaca-se por apresentarem a maioria dos participantes com Ensino Superior, porém este fato pode ser explicado pelo maior nível de renda dos moradores dessas duas regiões e por nessas regiões encontrarem-se os 2 campi da Universidade Estadual Paulista - UNESP. Na região 16 (Distrito de Itapé) houve a participação de apenas 2 moradores na reunião, sendo que um deles não respondeu a questão e o segundo possuía Ensino Superior, o que não revela a situação real de ensino da população desta região. Nas regiões 9 e 17, que consideramos como as mais carentes da cidade, observamos que há concentração de participantes que têm o Ensino Fundamental Incompleto, o que revela o baixo grau de instrução formal destas pessoas e a dificuldade de inserção no mercado de trabalho, visto que, hoje as empresas exigem no mínimo que seus funcionários tenham o Ensino Fundamental Completo. 
Tabela 3 - Escolaridade dos participantes das Reuniões Regionais do OP 2004 (\%)

\begin{tabular}{|c|c|c|c|c|c|c|c|c|c|c|}
\hline Região & $\begin{array}{c}\text { Fundam. } \\
\text { Completo }\end{array}$ & $\begin{array}{c}\text { Fundam. } \\
\text { Incompleto }\end{array}$ & $\begin{array}{c}\text { Médio } \\
\text { Comp. }\end{array}$ & $\begin{array}{c}\text { Médio } \\
\text { Incom. }\end{array}$ & $\begin{array}{c}\text { Superior } \\
\text { Compl. }\end{array}$ & $\begin{array}{c}\text { Superior } \\
\text { Incompl. }\end{array}$ & $\begin{array}{c}\text { Pós- } \\
\text { grad } \\
\text { Compl. }\end{array}$ & $\begin{array}{c}\text { Pós-grad } \\
\text { Incompl. }\end{array}$ & Analfabeto & $\begin{array}{c}\text { Sem } \\
\text { resposta }\end{array}$ \\
\hline $\mathbf{0 1}$ & 15 & 31 & 19 & 8 & zero & zero & 8 & zero & 4 & 15 \\
\hline $\mathbf{0 2}$ & 1 & 18 & 47 & zero & 21 & 21 & zero & zero & zero & 13 \\
\hline $\mathbf{0 3}$ & 24 & 33 & 27 & 13 & 3 & 3 & zero & zero & zero & zero \\
\hline $\mathbf{0 4}$ & 16 & 10 & 25 & 11 & 27 & 27 & 7 & zero & zero & 2 \\
\hline $\mathbf{0 5}$ & 22 & 19 & 32 & 12 & 4 & 4 & zero & zero & zero & 3 \\
\hline $\mathbf{0 6}$ & 16 & 56 & 12 & 4 & 1 & 1 & zero & zero & zero & 10 \\
\hline $\mathbf{0 7}$ & 16 & 11 & 35 & zero & 19 & 19 & 4 & zero & zero & zero \\
\hline $\mathbf{0 8}$ & 16 & 43 & 7 & zero & 14 & 14 & zero & 2 & 2 & 14 \\
\hline $\mathbf{0 9}$ & 10 & 57 & 8 & 2 & 2 & 2 & zero & zero & 4 & 13 \\
\hline $\mathbf{1 0}$ & 14 & 4 & 28 & zero & 41 & 41 & 3 & zero & zero & zero \\
\hline $\mathbf{1 1}$ & 21 & 6 & 53 & 5 & 10 & 10 & zero & zero & zero & zero \\
\hline $\mathbf{1 2}$ & 15 & 31 & 23 & 8 & 8 & 8 & zero & zero & zero & 7 \\
\hline $\mathbf{1 3}$ & 20 & 20 & 20 & 10 & 10 & 10 & 5 & zero & zero & 10 \\
\hline $\mathbf{1 4}$ & 34 & 33 & 33 & zero & zero & zero & zero & zero & zero & zero \\
\hline $\mathbf{1 5}$ & 8 & 23 & 15 & 8 & 15 & 15 & 8 & zero & zero & 23 \\
\hline $\mathbf{1 6}$ & zero & zero & zero & zero & 50 & 50 & zero & zero & zero & 50 \\
\hline $\mathbf{1 7}$ & 17 & 49 & 4 & 4 & 2 & 2 & zero & zero & 4 & 18 \\
\hline
\end{tabular}


Tabela 4 - Participação em reuniões anteriores do OP (\%)

\begin{tabular}{|c|c|c|c|}
\hline Regiões & $\begin{array}{c}\text { Já participou de } \\
\text { outras reuniões }\end{array}$ & $\begin{array}{c}\text { Nunca participou de } \\
\text { reuniões }\end{array}$ & Não respondeu \\
\hline $\mathbf{0 1}$ & 61 & 35 & 4 \\
\hline $\mathbf{0 2}$ & 32 & 68 & zero \\
\hline $\mathbf{0 3}$ & 40 & 60 & zero \\
\hline $\mathbf{0 4}$ & 30 & 68 & 2 \\
\hline $\mathbf{0 5}$ & 46 & 54 & zero \\
\hline $\mathbf{0 6}$ & 31 & 69 & zero \\
\hline $\mathbf{0 7}$ & 46 & 54 & zero \\
\hline $\mathbf{0 8}$ & 37 & 63 & zero \\
\hline $\mathbf{0 9}$ & 31 & 65 & zero \\
\hline $\mathbf{1 0}$ & 41 & 59 & zero \\
\hline $\mathbf{1 1}$ & 5 & 95 & zero \\
\hline $\mathbf{1 2}$ & 85 & 15 & 15 \\
\hline $\mathbf{1 3}$ & 40 & 45 & zero \\
\hline $\mathbf{1 4}$ & 50 & 50 & 8 \\
\hline $\mathbf{1 5}$ & 54 & 38 & zero \\
\hline $\mathbf{1 6}$ & 100 & zero & 7 \\
\hline $\mathbf{1 7}$ & 29 & 64 & \\
\hline
\end{tabular}

Para analisarmos o grau de envolvimento e de participação das pessoas que presenciaram as reuniões do OP, analisaremos as tabelas 4, 5 e 6.A tabela 4 mostra que, a grande maioria das pessoas que responderam ao questionário, participava pela primeira vez de uma reunião do OP. No entanto, essa maioria não é expressiva, percentualmente eles apresentam uma pequena maioria, em grande parte das regiões os resultados ficam equilibrados, concentrando a diferença na faixa dos $60 \%$. Na região $11,95 \%$ dos participantes integravam pela primeira vez o processo. Destacamos as regiões $12(85 \%)$ e 16 (100\%), onde grande parte dos participantes já havia participado de outras reuniões do OP. Este fato pode ser explicado pelo tamanho das comunidades, já que, as duas regiões não fazem parte da área urbana de Rio Claro e concentram um pequeno número de habitantes. Mas também evidencia que a mobilização não é muito grande, pois o número de participantes nestas regiões não é muito alto e são sempre as mesmas pessoas que participam.

Inicialmente supúnhamos que as pessoas que participavam das reuniões do OP estavam envolvidas em outros movimentos e atividades junto à comunidade. Esta hipótese fez com que inseríssemos esta pergunta no questionário que aplicamos com a população das regiões. As respostas nos surpreenderam, pois apenas a região 1 (Nordeste 1) apresentou $54 \%$ de seus participantes com 
envolvimento em outras atividades de participação na comunidade. Nas 16 regiões restantes a maioria das pessoas não exercia atividades de participação em nenhuma outra instância, seja ela governamental, religiosa ou educacional. Isso evidencia que a participação em ações comunitárias e envolvimento político não foi o que motivou a participação no processo do orçamento participativo, a motivação de participação neste processo está diretamente ligada a oportunidade de reivindicar questões emergenciais e imediatas que os afetam cotidianamente e, por isso, aparecem de volta nas reuniões.

Tabela 5 - Participação em entidades, associações, etc. (\%)

\begin{tabular}{|c|c|c|c|}
\hline Região & Participa & Não participa & Não respondeu \\
\hline $\mathbf{0 1}$ & 54 & 46 & zero \\
\hline $\mathbf{0 2}$ & 41 & 44 & 15 \\
\hline $\mathbf{0 3}$ & 33 & 57 & 10 \\
\hline $\mathbf{0 4}$ & 29 & 55 & 16 \\
\hline $\mathbf{0 5}$ & 16 & 75 & 9 \\
\hline $\mathbf{0 6}$ & 27 & 66 & 7 \\
\hline $\mathbf{0 7}$ & 23 & 58 & 19 \\
\hline $\mathbf{0 8}$ & 32 & 52 & 16 \\
\hline $\mathbf{0 9}$ & 20 & 53 & 27 \\
\hline $\mathbf{1 0}$ & 24 & 62 & 14 \\
\hline $\mathbf{1 1}$ & 5 & 79 & 16 \\
\hline $\mathbf{1 2}$ & 15 & 70 & 15 \\
\hline $\mathbf{1 3}$ & 10 & 70 & 20 \\
\hline $\mathbf{1 4}$ & 33 & 50 & 17 \\
\hline $\mathbf{1 5}$ & 33 & 50 & 17 \\
\hline $\mathbf{1 6}$ & 8 & 46 & 46 \\
\hline $\mathbf{1 7}$ & zero & 50 & 50 \\
\hline
\end{tabular}

A Tabela 6 nos mostra em quais outras atividades da comunidade os participantes do OP estão envolvidos. Essa questão foi respondida somente pelas pessoas que afirmavam participar de outras atividades comunitárias, ou seja, entidades, associações, partidos políticos, etc. A tabela mostra que a população participante de outras atividades está envolvida, principalmente, em associações de bairros, entidades religiosas. Esperava-se que a participação junto a partidos políticos fosse mais ampla, porém o questionário evidenciou que esta é quase inexistente, apenas na região 13 é que $50 \%$ dos participantes estavam envolvidos em partidos políticos. Isso nos mostra que o OP não tem uma vinculação direta com partidos políticos, como ocorre em outras práticas municipais do OP. 
Há uma porcentagem bastante significativa de participantes ligados as associações de bairros. Eles geralmente se unem para reivindicar obras para seu bairro, o que, na maioria das vezes, reflete a necessidade de um lugar, um centro comunitário, para que eles possam exercer suas atividades. Podemos destacar na análise das tabelas 5 e 6 a região 1, onde $54 \%$ dos participantes declararam participar de outras atividades da comunidade e destes 54\%, 72\% participavam de associações de bairro. Isto mostra que há um envolvimento da população junto aos problemas que os bairros enfrentam. As regiões 8 e 9, que fazem parte da periferia mais carente da cidade, embora percentualmente tenham poucos participantes que integrem atividades comunitárias; $32 \%$ e $20 \%$, respectivamente; possuem como principal envolvimento as associações de bairro. Ou seja, 78\% na região 8 e $80 \%$ na região 9.

A participação em outros conselhos temáticos da cidade também é bastante pequena, o que mostra uma desvinculação desses conselhos com a prática do orçamento participativo. Os representantes de ONGs, sindicatos, conselhos e associações escolares possuem participação quase inexistente junto ao OP.

Outro destaque é a região 3 , pois nesta região $83 \%$ dos participantes do OP eram mulheres adultas (30 a 49 anos) e dos $33 \%$, que afirmaram participar de entidades, associações e outras atividades, 30\% estavam ligadas a conselhos e associações escolares. Estes dados podem nos indicar que são, principalmente, as mães que tem seus filhos em idade escolar, que se dispõe a discutir e apresentar os problemas pelos quais a população passa.

Já o destaque para a região 15 , Batovi, é o de que dos $33 \%$ de participantes que declararam fazer parte de outras atividades comunitárias, $100 \%$ faz parte de entidades religiosas, o que mostra que neste distrito há uma mobilização influenciada pela igreja, que muitas vezes, está envolvida nos problemas enfrentados pela população.

A análise, das seis tabelas, que são resultado de pesquisa realizada entre a população presente nas reuniões do OP de Rio Claro, nos revela que estes participantes são em sua maioria mulheres e homens em idade adulta; com maior índice a participação feminina com escolaridade baixa, pois a grande parte não concluiu o ensino fundamental, considerado o básico para a educação e, que não tem grande envolvimento em movimentos sociais e outras atividades ligadas à comunidade. A minoria dos participantes que exercem outro tipo de atividades 

em Rio Claro/SP.

participativas comunitárias está ligada, principalmente, às associações de moradores, conselhos e associações de escolas e entidades religiosas.

Tabela 6 - Entidades ou associações que a população participa (\%)

\begin{tabular}{|l|c|l|l|c|c|c|c|c|c|}
\hline Região & $\begin{array}{c}\text { Associaç̃̃es } \\
\text { de bairro }\end{array}$ & ONG's & Sindicatos & $\begin{array}{c}\text { Conselhos } \\
\text { municipais }\end{array}$ & $\begin{array}{c}\text { Conselhos, } \\
\text { associações } \\
\text { escolares }\end{array}$ & $\begin{array}{c}\text { Entidade } \\
\text { religiosa }\end{array}$ & $\begin{array}{c}\text { Partidos } \\
\text { Políticos }\end{array}$ & $\begin{array}{c}\text { Demais } \\
\text { entidades }\end{array}$ & $\begin{array}{c}\text { Não } \\
\text { respondeu }\end{array}$ \\
\hline $\mathbf{0 1}$ & 72 & 7 & 7 & zero & zero & 7 & zero & 7 & zero \\
\hline $\mathbf{0 2}$ & 7 & zero & 7 & 21 & zero & 29 & zero & 36 & zero \\
\hline $\mathbf{0 3}$ & 20 & zero & zero & 10 & 30 & 10 & zero & 30 & zero \\
\hline $\mathbf{0 4}$ & 46 & zero & zero & zero & 8 & 8 & zero & 38 & zero \\
\hline $\mathbf{0 5}$ & 13 & zero & 6 & zero & 6 & 37 & zero & 25 & 13 \\
\hline $\mathbf{0 6}$ & $\mathbf{2 0}$ & zero & zero & 8 & 8 & 20 & zero & 36 & 8 \\
\hline $\mathbf{0 7}$ & 66 & zero & zero & 17 & zero & 17 & zero & zero & zero \\
\hline $\mathbf{0 8}$ & 78 & zero & zero & zero & zero & 16 & zero & 6 & zero \\
\hline $\mathbf{0 9}$ & 80 & zero & zero & zero & zero & 10 & zero & 10 & zero \\
\hline $\mathbf{1 0}$ & zero & zero & zero & zero & zero & 14 & zero & 86 & zero \\
\hline $\mathbf{1 1}$ & zero & zero & zero & zero & zero & zero & zero & 100 & zero \\
\hline $\mathbf{1 2}$ & zero & zero & zero & zero & 50 & 50 & zero & zero & zero \\
\hline $\mathbf{1 3}$ & zero & zero & zero & 50 & zero & zero & 50 & zero & zero \\
\hline $\mathbf{1 4}$ & zero & zero & zero & zero & zero & 50 & zero & 50 & zero \\
\hline $\mathbf{1 5}$ & zero & zero & zero & zero & zero & 100 & zero & zero & zero \\
\hline $\mathbf{1 6}$ & zero & zero & zero & zero & zero & zero & zero & zero & zero \\
\hline $\mathbf{1 7}$ & 61 & zero & zero & zero & 8 & zero & zero & 23 & 8 \\
\hline
\end{tabular}

\section{Prioridades}

As reuniões regionais do OP de Rio Claro/SP traziam inicialmente a discussão de prioridades para os bairros. O bairro aparece como "referencial de vida", pois é no bairro que se realiza a prática sócio-espacial e onde a vida se realiza. Há uma identidade criada, com o tempo, entre o habitante e o bairro. $O$ habitante se identifica com esse espaço específico (bairro) e este se torna o referencial para a sua vida, para a prática urbana.

As prioridades elencadas pelos moradores nos bairros, na primeira fase do $\mathrm{OP}$, revelam a busca por melhoramentos de serviços e infra-estrutura, que se referem a uma vida conjunta nesse espaço. As prioridades que se referem a questões individuais, podem aparecer nas reuniões, mas em número bastante reduzido e logo são descartadas pelos participantes. As prioridades dizem respeito ao conjunto do bairro, revelando uma solidariedade entre moradores desse espaço.

Mas o que essas prioridades elencadas pela população dos bairros pode nos revelar sobre a produção do espaço urbano? Nas páginas seguintes, apresentamos os quadros das prioridades dos bairros, resultado das reuniões regionais do OP, que 

em Rio Claro/SP.

aconteceram no ano de 2004. São 17 regiões, formadas por 84 bairros, 4 distritos e 1 vila rural, onde cada uma destas elementos possuem três prioridades classificadas de $1^{\text {a }}$ a $3^{\text {a }}$, segundo sua importância para o conjunto da população do bairro. Nos concentraremos na análise dos bairros que compõe a área urbana do município, que é objeto de análise de nossa dissertação.

Quadro 1 - Prioridades Discutidas nas Reuniões do Orçamento Participativo 2004 REGIÃO 1 - NORDESTE I

\begin{tabular}{|c|c|c|c|}
\hline BAIRRO & 1ª PRIORIDADE & $2^{\text {a }}$ PRIORIDADE & $3^{\text {a }}$ PRIORIDADE \\
\hline Mãe Preta & $\begin{array}{l}\text { Mais uma equipe de } \\
\text { médicos e construção } \\
\text { de prédio próprio para } \\
\text { função do PSF( } \\
\text { Programa Saúde da } \\
\text { Família) no centro } \\
\text { comunitário }\end{array}$ & $\begin{array}{l}\text { Implantação de } \\
\text { redutores de } \\
\text { velocidade nos dois } \\
\text { sentidos da avenida } \\
\text { 1MP (Mãe Preta). }\end{array}$ & $\begin{array}{l}\text { Construção de um } \\
\text { campo de futebol, } \\
\text { visando tirar jovens } \\
\text { das drogas e levá-los } \\
\text { para a prática } \\
\text { esportiva }\end{array}$ \\
\hline Residencial Florença & $\begin{array}{l}\text { Acostamento da rua } \\
\text { dos Estudantes até a } \\
\text { Rodovia }\end{array}$ & $\begin{array}{l}\text { Tratamento de } \\
\text { erosões no } \\
\text { Residencial Florença }\end{array}$ & $\begin{array}{l}\text { Rede de esgoto no } \\
\text { Residencial Florença }\end{array}$ \\
\hline Vila Verde & $\begin{array}{l}\text { Implantação de } \\
\text { rotatória próximo a } \\
\text { Creche Monteiro } \\
\text { Lobato, para fluir com } \\
\text { segurança o trânsito. } \\
\text { A falta de uma } \\
\text { rotatória provoca } \\
\text { trânsito intenso dentro } \\
\text { do residencial Vila } \\
\text { Verde, que no projeto } \\
\text { inicial está como } \\
\text { condomínio fechado }\end{array}$ & $\begin{array}{l}\text { Malha de lazer } \\
\text { abrangendo Vila } \\
\text { Verde, Mãe Preta e } \\
\text { Vila Industrial }\end{array}$ & $\begin{array}{l}\text { Identificação de ruas } \\
\text { com placas, para } \\
\text { melhor orientação }\end{array}$ \\
\hline Vila Industrial & Asfalto & $\begin{array}{l}\text { A garantia de } \\
\text { travessia segura para } \\
\text { acesso das crianças } \\
\text { da Vila Industrial para } \\
\text { a escola da Mãe } \\
\text { Preta }\end{array}$ & $\begin{array}{l}\text { Um galpão de múltiplo } \\
\text { uso (lazer, esporte, } \\
\text { reuniões) para a Vila } \\
\text { Industrial }\end{array}$ \\
\hline
\end{tabular}


REGIÃO 2 - NORDESTE II

\begin{tabular}{|c|c|c|c|}
\hline BAIRRO & $1^{\text {a }}$ PRIORIDADE & $2^{\mathrm{a}} \mathrm{PRIORIDADE}$ & $3^{\mathrm{a}}$ PRIORIDADE \\
\hline São Miguel & $\begin{array}{l}\text { São Miguel (Pé no } \\
\text { Chão) precisamos } \\
\text { do asfalto }\end{array}$ & $\begin{array}{l}\text { Centro Comunitário no } \\
\text { São Miguel I, o outro } \\
\text { Centro Comunitário é } \\
\text { no Pé no Chão e fica } \\
\text { longe }\end{array}$ & $\begin{array}{l}\text { Precisamos de um } \\
\text { projeto para nossas } \\
\text { crianças do São Miguel } \\
\text { I }\end{array}$ \\
\hline $\begin{array}{l}\text { Residencial Orestes } \\
\text { Armando Giovanni }\end{array}$ & $\begin{array}{l}\text { Asfaltamento do } \\
\text { bairro para evitar } \\
\text { poeira, lama e } \\
\text { problemas } \\
\text { respiratórios }\end{array}$ & $\begin{array}{l}\text { Remanejamento da } \\
\text { linha do ônibus da } \\
\text { linha São Miguel } \\
\text { ouvindo a comunidade } \\
\text { Regulamentação dos } \\
\text { terrenos das casas }\end{array}$ & $\begin{array}{l}\text { Cursos } \\
\text { profissionalizantes e } \\
\text { projeto com atividades } \\
\text { para crianças e } \\
\text { adolescentes de } 7 \text { a } 14 \\
\text { anos }\end{array}$ \\
\hline Jardim Vilage & $\begin{array}{l}\text { Solicito estudo na } \\
\text { avenida } 80-A \text { e rua } \\
14 \text { do Jardim Vilage } \\
\text { para reduzir } \\
\text { acidentes }\end{array}$ & & \\
\hline Jardim América & $\begin{array}{l}\text { Transformar em } \\
\text { bosque a praça junto } \\
\text { ao } 2^{\circ} \text { DP (Distrito } \\
\text { Policial), entre as } \\
\text { avenidas } 56 \text { e 58-A e } \\
\text { ruas } 6 \text { e } 7 \text { - }^{\circ}\end{array}$ & $\begin{array}{l}\text { Instalação de quadra } \\
\text { Poliesportiva no Clube } \\
9 \text { de julho e pista de } \\
\text { Cooper }\end{array}$ & $\begin{array}{l}\text { Ajardinamento e } \\
\text { reforma geral da praça } \\
\text { localizada na avenida } \\
\text { José Felício Castelano } \\
\text { com a avenida } 64-A \\
\text { coma a rua } 10-J A .\end{array}$ \\
\hline Vila Nova & $\begin{array}{l}\text { Asfaltamento do } \\
\text { Anel Viário da } \\
\text { Unesp, arborização } \\
\text { do local }\end{array}$ & $\begin{array}{l}\text { Realização de galerias } \\
\text { e asfaltamento } \\
\text { "antiga" Estrada da } \\
\text { Bomba" }\end{array}$ & \\
\hline Vila Alemã & $\begin{array}{l}\text { Ampliação da EMEl } \\
\text { (Escola Municipal de } \\
\text { Ensino Infantil) D. } \\
\text { Pedro I }\end{array}$ & $\begin{array}{l}\text { Melhor escoamento } \\
\text { de águas ao longo da } \\
\text { rua } 6-A\end{array}$ & $\begin{array}{l}\text { Melhorias na } \\
\text { sinalização de trânsito }\end{array}$ \\
\hline Jardim Ipê & $\begin{array}{l}\text { Rondas noturnas de } \\
\text { Segurança Pública, } \\
\text { ou mesmo pela } \\
\text { Guarda Municipal }\end{array}$ & $\begin{array}{l}\text { Campanha contra as } \\
\text { pichações e outros } \\
\text { prejuízos aos } \\
\text { moradores do bairro }\end{array}$ & $\begin{array}{l}\text { Para atender a } 1^{\text {a }} \\
\text { prioridade: aumentar o } \\
\text { número de Guardas } \\
\text { Municipais }\end{array}$ \\
\hline Vila São José & $\begin{array}{l}\text { Conclusão da galeria } \\
\text { de águas pluviais } \\
\text { provenientes do } \\
\text { Nosso Teto até a } \\
\text { Avenida José Felício } \\
\text { Castelano }\end{array}$ & $\begin{array}{l}\text { Asfaltamento da } \\
\text { avenida Joaquim } \\
\text { Ribeiro e 58-A }\end{array}$ & $\begin{array}{l}\text { Criação de área de } \\
\text { lazer no terreno da } \\
\text { área citada no item 2, } \\
\text { para acabar com o } \\
\text { lixão ali existente }\end{array}$ \\
\hline $\begin{array}{l}\text { Jardim } \\
\text { Bandeirantes }\end{array}$ & $\begin{array}{l}\text { Maior incentivo a } \\
\text { prática de esportes } \\
\text { (escolinhas e } \\
\text { projetos envolvendo } \\
\text { toda a comunidade) } \\
\text { conjuntamente com } \\
\text { a construção de } \\
\text { áreas de lazer }\end{array}$ & $\begin{array}{l}\text { Lombadas nas ruas } 1, \\
3,14 \text { (alto fluxo de } \\
\text { veículos) }\end{array}$ & $\begin{array}{l}\text { Recapeamento do } \\
\text { asfalto das ruas, bem } \\
\text { como limpeza das } \\
\text { galerias e construção } \\
\text { de novas galerias }\end{array}$ \\
\hline $\begin{array}{l}\text { Jardim Parque } \\
\text { Residencial }\end{array}$ & $\begin{array}{l}\text { Asfaltamento da } \\
\text { avenida Torque }\end{array}$ & $\begin{array}{l}\text { Construção de praça } \\
\text { na av. 80-A enfrente } \\
\text { ao prédio Village junto } \\
\text { com área de lazer }\end{array}$ & $\begin{array}{l}\text { Linha de ônibus que } \\
\text { passe pelo bairro }\end{array}$ \\
\hline
\end{tabular}



em Rio Claro/SP.

REGIÃO 3 - NORTE

\begin{tabular}{|c|c|c|c|}
\hline BAIRRO & $1^{\text {a }}$ PRIORIDADE & $2^{\mathrm{a}}$ PRIORIDADE & $3^{a}$ PRIORIDADE \\
\hline Jardim Floridiana & $\begin{array}{l}\text { Mini rotatória no } \\
\text { cruzamento da } \\
\text { avenida M-23/ } \\
\text { avenida } 2 \mathrm{JF} \text {, lixeiras } \\
\text { para lixo reciclável }\end{array}$ & $\begin{array}{l}\text { Construção de calçadas } \\
\text { em todos os terrenos } \\
\text { baldios do bairro, } \\
\text { varredores de rua. }\end{array}$ & $\begin{array}{l}\text { Construção da praça } \\
\text { dos Eucaliptos e } \\
\text { Fernando Sartori }\end{array}$ \\
\hline $\begin{array}{l}\text { Jardim } \\
\text { Independência }\end{array}$ & $\begin{array}{l}\text { Ampliação da } \\
\text { biblioteca do } \\
\text { Cervezão, com } \\
\text { amplo salão cultural }\end{array}$ & $\begin{array}{l}\text { Verbas para curso de } \\
\text { capacitação para a } \\
\text { comunidade no Centro } \\
\text { Comunitário } \\
\text { (informática, } \\
\text { cabelereiro, etc.) }\end{array}$ & $\begin{array}{l}\text { Construção de um } \\
\text { novo Centro de } \\
\text { Convivência infantil } \\
\text { para acolher } \\
\text { crianças e } \\
\text { adolescentes no } \\
\text { período extra- } \\
\text { escolar, porque o } \\
\text { que funciona na M- } \\
14 \text { com a M-25 não } \\
\text { atende a demanda, } \\
\text { porque temos uma } \\
\text { fila de espera muito } \\
\text { grande }\end{array}$ \\
\hline Jardim Hipódromo & $\begin{array}{l}\text { Na área da rua M-7 } \\
\text { com avenida M- } 25 \text { e } \\
\text { M-27 queremos que } \\
\text { fosse construída } \\
\text { porque só há sujeira. } \\
\text { Pode-se construir } \\
\text { uma creche ou um } \\
\text { jardim }\end{array}$ & $\begin{array}{l}\text { Queremos uma área } \\
\text { para a prática de } \\
\text { esportes e lazer dos } \\
\text { jovens } \\
\text { OBS:Lago Azul deve } \\
\text { ser como o Lago de } \\
\text { Araras }\end{array}$ & $\begin{array}{l}\text { Criação de uma } \\
\text { cooperativa para } \\
\text { pessoas acima de } \\
40 \text { anos, porque } \\
\text { nessa idade há } \\
\text { dificuldade para } \\
\text { conseguir trabalho }\end{array}$ \\
\hline $\begin{array}{l}\text { Parque das } \\
\text { Indústrias }\end{array}$ & $\begin{array}{l}\text { Quadra coberta na } \\
\text { EMIEF Victorino } \\
\text { Machado }\end{array}$ & $\begin{array}{l}\text { Biblioteca com sala de } \\
\text { informática (para as } \\
\text { aulas) }\end{array}$ & $\begin{array}{l}\text { Construção de uma } \\
\text { piscina e construção } \\
\text { da porta da entrada } \\
\text { da EMEIEF (Escola } \\
\text { Municipal de Ensino } \\
\text { Infantil e } \\
\text { Fundamental) } \\
\text { Victorino Machado }\end{array}$ \\
\hline Jardim Ipanema & $\begin{array}{l}\text { Construção de uma } \\
\text { galeria de águas } \\
\text { pluviais na Av. M-33 } \\
\text { com as ruas M-17 e } \\
\text { M-18, ligando a } \\
\text { galeria da avenida } \\
\text { M-35 }\end{array}$ & $\begin{array}{l}\text { Recapeamento da rua } \\
\text { M-18, da avenida M-31 } \\
\text { até a avenida M-37 }\end{array}$ & $\begin{array}{l}\text { Passeio público na } \\
\text { av. M-25, da rua M- } \\
20 \text { até a rua } 6 \\
\text { OBS: Término do } \\
\text { Centro Comunitário } \\
\text { do Jardim Ipanema }\end{array}$ \\
\hline Cervezão & $\begin{array}{l}\text { Ampliação do } \\
\text { espaço físico da } \\
\text { Biblioteca Zeverina } \\
\text { Quilici Tedesco, para } \\
\text { melhor atender os } \\
\text { usuários }\end{array}$ & $\begin{array}{l}\text { Cursos } \\
\text { profissionalizantes e } \\
\text { aquisição de dois } \\
\text { computadores } \\
\text { completos para uso da } \\
\text { comunidade }\end{array}$ & $\begin{array}{l}\text { Construção de mais } \\
\text { um Centro de } \\
\text { Convivência para } \\
\text { crianças e } \\
\text { adolescentes em } \\
\text { período extra- } \\
\text { escolar, para } \\
\text { atender a lista de } \\
\text { espera que já conta } \\
\text { com } 200 \text { pedidos de } \\
\text { vagas. }\end{array}$ \\
\hline
\end{tabular}


REGIÃO 4- LESTE

\begin{tabular}{|c|c|c|c|}
\hline BAIRRO & $1^{\mathrm{a}}$ PRIORIDADE & $2^{a}$ PRIORIDADE & $3^{a}$ PRIORIDADE \\
\hline Vila Indaiá & $\begin{array}{l}\text { Calçamento, } \\
\text { iluminação, } \\
\text { sinalização e } \\
\text { arborização da } \\
\text { Avenida Ulisses } \\
\text { Guimarães, para } \\
\text { caminhada }\end{array}$ & $\begin{array}{l}\text { Instalação de } \\
\text { parquinho, com } \\
\text { brinquedos, na praça } \\
\text { entre as avenidas } 8 \text { e } \\
12\end{array}$ & $\begin{array}{l}\text { Cancela de controle, } \\
\text { ou possível } \\
\text { fechamento da } \\
\text { passagem de acesso } \\
\text { ao Horto, pela Vila } \\
\text { Bela }\end{array}$ \\
\hline Vila Bela & $\begin{array}{l}\text { Construção de } \\
\text { estações de } \\
\text { atividades físicas na } \\
\text { praça da rua 12-B } \\
\text { com avenida Nossa } \\
\text { Senhora da Saúde }\end{array}$ & $\begin{array}{l}\text { Sinalização das ruas } \\
\text { do bairro e sinalização } \\
\text { de trânsito }\end{array}$ & $\begin{array}{l}\text { Melhoria no } \\
\text { paisagismo do bairro }\end{array}$ \\
\hline Vila Paulista & $\begin{array}{l}\text { Construção de uma } \\
\text { Unidade de Saúde da } \\
\text { Família }\end{array}$ & $\begin{array}{l}\text { Calçadão da rua P-3 } \\
\text { da avenida P-27 a P- } \\
43\end{array}$ & Segurança \\
\hline Bela Vista & $\begin{array}{l}\text { Construção na escola } \\
\text { EMEIF (Escola } \\
\text { Municipal de Ensino } \\
\text { Infantil e } \\
\text { Fundamental) Elpídio } \\
\text { Mina, melhorando seu } \\
\text { atendimento com } 2 \\
\text { salas de aula, } 1 \\
\text { laboratório e } 1 \text { quadra } \\
\text { esportiva }\end{array}$ & $\begin{array}{l}\text { Construção de uma } \\
\text { Unidade de Saúde da } \\
\text { Família no bairro }\end{array}$ & $\begin{array}{l}\text { Construção de trilha } \\
\text { no canteiro central e } \\
\text { calçamento nas } \\
\text { laterais da avenida } \\
\text { Ulisses Guimarães, } \\
\text { com ampliação do } \\
\text { circuito esportivo até a } \\
\text { Praça dos Eucaliptos, } \\
\text { com a construção de } \\
\text { uma estação de } \\
\text { atividades físicas }\end{array}$ \\
\hline Jardim Conduta & $\begin{array}{l}\text { U.B.S. (Unidade } \\
\text { Básica de Saúde) }\end{array}$ & $\begin{array}{l}\text { Calçadão na } \\
\text { "Constantino Peruche" }\end{array}$ & $\begin{array}{l}\text { Segurança } \\
\text { Erosão da avenida P- } \\
43\end{array}$ \\
\hline Cidade Nova & $\begin{array}{l}\text { Ampliação da parte } \\
\text { administrativa da } \\
\text { EMEI ( Escola } \\
\text { Municipal de Ensino } \\
\text { Infantil) com a } \\
\text { construção de um } \\
\text { barracão para } \\
\text { atividades, com } \\
\text { iluminação }\end{array}$ & $\begin{array}{l}\text { Alargamento do } \\
\text { pontilhão da avenida } 7\end{array}$ & $\begin{array}{l}\text { Revitalizar a Praça } \\
\text { dos Artesãos } \\
\text { (exemplo: a praça de } \\
\text { artesanato em frente } \\
\text { ao Sesc de Santos), } \\
\text { com guarita policial. }\end{array}$ \\
\hline
\end{tabular}


REGIÃO 5 - SUDESTE

\begin{tabular}{|c|c|c|c|}
\hline BAIRRO & $1^{\text {a }}$ PRIORIDADE & $2^{\mathrm{a}}$ PRIORIDADE & $3^{a}$ PRIORIDADE \\
\hline Bairro do Estádio & $\begin{array}{l}\text { Quadra de esporte } \\
\text { para escola Maria } \\
\text { Marrote }\end{array}$ & $\begin{array}{l}\text { Creche (sendo } \\
\text { berçário período } \\
\text { integral). }\end{array}$ & $\begin{array}{l}\text { Pavimentação, limpeza, } \\
\text { galeria pluvial, próximo a } \\
\text { Riclan e ronda policial à } \\
\text { noite, principalmente nas } \\
\text { praças. }\end{array}$ \\
\hline Jardim Quitandinha & $\begin{array}{l}\text { Quadra de esporte } \\
\text { para escola Maria } \\
\text { Marrote }\end{array}$ & $\begin{array}{l}\text { Recapeamento, } \\
\text { iluminação, limpeza } \\
\text { pública }\end{array}$ & $\begin{array}{l}\text { Unidade de Corpo de } \\
\text { Bombeiros - região Sudeste }\end{array}$ \\
\hline Vila Santo Antonio & $\begin{array}{l}\text { Solicitamos reparo } \\
\text { nas ruas e avenidas } \\
\text { (tapa buraco) }\end{array}$ & $\begin{array}{l}\text { Término da galeria da } \\
\text { avenida Marginal da } \\
\text { Fepasa, avenida } 29 \\
\text { até a ligação com a } \\
\text { galeria da rua } 6 \text {, que } \\
\text { sai atrás do edifício } \\
\text { Tilápias. Galeria esta } \\
\text { de concreto a av. } \\
\text { aberto margeando a } \\
\text { ferrovia, com início na } \\
\text { avenida } 29 \text { e término } \\
\text { na avenida } 43 \\
\text { desembocando na } \\
\text { galeria ali existente } \\
\text { para finalmente } \\
\text { atravessar a linha da } \\
\text { Fepasa. }\end{array}$ & \\
\hline Jardim do Trevo & $\begin{array}{l}\text { Solução para o } \\
\text { problema de água } \\
\text { que fica parada perto } \\
\text { da garagem da } \\
\text { empresa de ônibus } \\
\text { José Alexandre Jr., } \\
\text { sendo que junta } \\
\text { muitos pernilongos } \\
\text { por causa da água } \\
\text { parada. Quando } \\
\text { chove muito causa } \\
\text { enchente, com a } \\
\text { água chegando em } \\
\text { nível muito alto. }\end{array}$ & & \\
\hline
\end{tabular}



em Rio Claro/SP.

REGIÃO 6 - SUL

\begin{tabular}{|c|c|c|c|}
\hline BAIRRO & $1^{\text {a }}$ PRIORIDADE & $2^{\mathrm{a}}$ PRIORIDADE & $3^{a}$ PRIORIDADE \\
\hline $\begin{array}{l}\text { Jardim das } \\
\text { Palmeiras }\end{array}$ & $\begin{array}{l}\text { lluminação no bairro e } \\
\text { mudança no itinerário de } \\
\text { ônibus, pois este passa } \\
\text { na rua } 18 \text { enfrente ao } \\
\text { CAIC (Centro de Atenção } \\
\text { Integral à Criança) } \\
\text { durante a entrada e saída } \\
\text { de alunos, isso já trouxe } \\
\text { acidentes e vários } \\
\text { problemas }\end{array}$ & $\begin{array}{l}\text { Viatura e ambulância } \\
\text { durante a noite (18:00 } \\
\text { as } 06: 00)\end{array}$ & $\begin{array}{l}\text { Ampliação da creche do } \\
\text { bairro }\end{array}$ \\
\hline Jardim Guanabara I & $\begin{array}{l}\text { Centro Comunitário } \\
\text { (barracão), no espaço da } \\
\text { rua } 11 \text { com avenida } 11\end{array}$ & $\begin{array}{l}\text { Cooperativa - entre- } \\
\text { pasto }\end{array}$ & $\begin{array}{l}\text { Área de lazer na rua } 2, \\
\text { ao lado da linha férrea }\end{array}$ \\
\hline Jardim Guanabara II & $\begin{array}{l}\text { Asfalto - é promessa } \\
\text { deste governo e do } \\
\text { anterior, em OP passados } \\
\text { foi citado esta melhoria, } \\
\text { mas até o momento nada }\end{array}$ & $\begin{array}{l}\text { Cooperativa de } \\
\text { reciclagem de } \\
\text { materiais }\end{array}$ & $\begin{array}{l}\text { Área de lazer na } \\
\text { avenida } 10 .\end{array}$ \\
\hline Jardim Brasília I & $\begin{array}{l}\text { Reforma da escola CAIC } \\
\text { (Centro de Atenção } \\
\text { Integral à Criança) }\end{array}$ & $\begin{array}{l}\text { Área de lazer da } \\
\text { comunidade do Jd } \\
\text { Brasília I. Ex: A } \\
\text { iluminação da área }\end{array}$ & $\begin{array}{l}\text { Montagem da } \\
\text { cooperativa e interposto }\end{array}$ \\
\hline Jardim Brasília II & $\begin{array}{l}\text { Galerias para receber o } \\
\text { asfalto }\end{array}$ & $\begin{array}{l}\text { Cursos } \\
\text { profissionalizantes, } \\
\text { visando a formação } \\
\text { de cooperativas para } \\
\text { geração de renda } \\
\text { (artesanato, } \\
\text { reciclagem de } \\
\text { materiais) }\end{array}$ & $\begin{array}{l}\text { Praça de lazer na } \\
\text { avenida } 16 \text { com ruas } 5 \\
\text { e } 6 \text {, ao lado da escola } \\
\text { EMEI (Escola Municipal } \\
\text { de Ensino Infantil) } \\
\text { Isolina Huppert } \\
\text { Cassavia }\end{array}$ \\
\hline Jardim Novo I & $\begin{array}{l}\text { Centro Comunitário } \\
\text { amplo, com área de lazer } \\
\text { e arborização em todo o } \\
\text { bairro }\end{array}$ & $\begin{array}{l}\text { Área e construção de } \\
\text { um prédio para o } 4^{\circ} \\
\text { Distrito e Corpo de } \\
\text { Bombeiros da região } \\
\text { sul }\end{array}$ & $\begin{array}{l}\text { Complemento de } \\
\text { iluminação no bairro. } \\
\text { Ex: ligação Jd Novo I e } \\
\text { Novo II }\end{array}$ \\
\hline Jardim Novo II & $\begin{array}{l}\text { Definir o que vai ser } \\
\text { realizado na viela (área } \\
\text { verde) da rua } 1 \text { a } 76 \text { e } 6 \text { a } \\
10 \text { entre avenidas } 12 \text { e } \\
14 \text {. Arrumar o campo já } \\
\text { existente ao lado }\end{array}$ & $\begin{array}{l}\text { Play-ground, fazer } \\
\text { campo de areia. } \\
\text { Reformar UBS } \\
\text { (Unidade Básica de } \\
\text { Saúde) }\end{array}$ & $\begin{array}{l}\text { lluminação na Estrada } \\
\text { dos Costas e na escola } \\
\text { CAIC }\end{array}$ \\
\hline $\begin{array}{l}\text { Jardim Nova Rio } \\
\text { Claro }\end{array}$ & $\begin{array}{l}\text { Duplicação da ponte de } \\
\text { acesso ao bairro. Asfalto } \\
\text { e pavimentação }\end{array}$ & $\begin{array}{l}\text { Centro Comunitário } \\
\text { para atendimento das } \\
\text { reclamações sociais, } \\
\text { etc. }\end{array}$ & $\begin{array}{l}\text { Ônibus com menos } \\
\text { tempo de espera, no } \\
\text { mínimo de uma em uma } \\
\text { hora. Atualmente } \\
\text { demora uma hora e } \\
\text { quarenta minutos }\end{array}$ \\
\hline Jardim Inocoop & $\begin{array}{l}\text { Resolução dos problemas } \\
\text { de enchentes na Avenida } \\
\text { Tancredo Neves }\end{array}$ & $\begin{array}{l}\text { Passarelas (vielas). } \\
\text { Mão de direção nas } \\
\text { ruas, sinalização }\end{array}$ & $\begin{array}{l}\text { Marginal (córrego) } \\
\text { Viviane (lateral) paralela } \\
\text { a Estrada dos Costas }\end{array}$ \\
\hline
\end{tabular}


REGIÃO 7 - SUDOESTE

\begin{tabular}{|c|c|c|c|}
\hline BAIRRO & $1^{a}$ PRIORIDADE & $2^{\mathrm{a}}$ PRIORIDADE & $3^{a}$ PRIORIDADE \\
\hline Jardim São Paulo I & Asfalto & $\begin{array}{l}\text { Melhoria da } \\
\text { iluminação pública }\end{array}$ & $\begin{array}{l}\text { Identificação das ruas. OBS: } \\
\text { Criar legislação para "murar" } \\
\text { os terrenos baldios e colocar } \\
\text { calçadinhas } \\
\text { Calçada em frente a escola } \\
\text { Odilon Correia. Pintar e } \\
\text { sinalizar o solo na escola } \\
\text { Odilon Correia }\end{array}$ \\
\hline Jardim São Paulo II & $\begin{array}{l}\text { Asfalto é sempre o } \\
\text { que a gente pede, e } \\
\text { bate na mesma tecla. } \\
\text { Asfalto em pontas de } \\
\text { esquina }\end{array}$ & $\begin{array}{l}\text { Mato é cortado muito } \\
\text { mal }\end{array}$ & $\begin{array}{l}\text { Transportadora abriu uma } \\
\text { rua num terreno na rua } 29 \\
\text { com avenida } 10-\mathrm{A} \text { e } 10-\mathrm{B} \text { e } \\
\text { usa como rua para } \\
\text { caminhões, carros, etc. }\end{array}$ \\
\hline $\begin{array}{l}\text { Residencial dos } \\
\text { Bosques }\end{array}$ & Lixeiras de gradil & $\begin{array}{l}\text { Continuação do } \\
\text { projeto de } \\
\text { preservação, } \\
\text { urbanização e } \\
\text { paisagismo da rua } 4 \\
\text { entre avs. } 4 \text { e } 8 \text { e da } \\
\text { rua } 3 .\end{array}$ & \\
\hline Jardim Paulista I & Galerias de água & $\begin{array}{l}\text { Preservação das ruas } \\
\text { (constante) }\end{array}$ & $\begin{array}{l}\text { Centro Comunitário } \\
\text { (conjunto com Nova } \\
\text { Veneza) }\end{array}$ \\
\hline $\begin{array}{l}\text { Jardim Nova } \\
\text { Veneza }\end{array}$ & Ônibus circular & Galeria e cascalho & $\begin{array}{l}\text { Centro comunitário (conjunto } \\
\text { com Jd Paulista I) }\end{array}$ \\
\hline Granja Regina & Galerias & Asfalto & Área verde \\
\hline Jardim Mirassol & $\begin{array}{l}\text { Canalização e } \\
\text { urbanização do } \\
\text { córrego }\end{array}$ & $\begin{array}{l}\text { Sinalização e } \\
\text { identificação das ruas } \\
\text { e avenidas }\end{array}$ & $\begin{array}{l}\text { lluminação pública nas ruas } \\
\text { periféricas do bairro } \\
\text { OBS: Lombadas ou outro } \\
\text { artifício que não as } \\
\text { tartarugas, para controle da } \\
\text { velocidade dos veículos, } \\
\text { principalmente na avenida } 8 \\
\text { e, na rua } 23 \text { entre avs. } 5 \text { até } \\
\text { a av. } 4\end{array}$ \\
\hline $\begin{array}{l}\text { Jardim Maria } \\
\text { Cristina }\end{array}$ & Asfalto com galerias & $\begin{array}{l}\text { Manutenção do } \\
\text { bairro, tratores para } \\
\text { roçar o mato que } \\
\text { invadem as casas }\end{array}$ & Melhor iluminação \\
\hline Jardim Claret & $\begin{array}{l}\text { Construção e } \\
\text { funcionamento da } 2^{a} \\
\text { Unidade do Corpo de } \\
\text { Bombeiros em Rio } \\
\text { Claro, se possível no } \\
\text { terreno da lado da } \\
\text { rodoviária }\end{array}$ & $\begin{array}{l}\text { Abertura da rua } \\
\text { Marginal do Córrego, } \\
\text { do terminal rodoviário } \\
\text { até avenida } 8\end{array}$ & $\begin{array}{l}\text { Demarcação correta das } \\
\text { ruas e avenidas no entorno } \\
\text { das Faculdades Claretianas } \\
\text { e Colégio Integrado }\end{array}$ \\
\hline $\begin{array}{l}\text { Residencial } \\
\text { Benjamim de Castro }\end{array}$ & Lixeiras de gradil & $\begin{array}{l}\text { Asfaltamento da } \\
\text { avenida } 11 \text { (antiga } \\
\text { estrada de Ipeúna) }\end{array}$ & $\begin{array}{l}\text { Projeto paisagístico das } \\
\text { áreas de preservação (rua } \\
\text { 4) e institucional (rua 3) }\end{array}$ \\
\hline
\end{tabular}


REGIÃO 8 - OESTE

\begin{tabular}{|c|c|c|c|}
\hline BAIRRO & $1^{\text {a }}$ PRIORIDADE & $2^{\mathrm{a}}$ PRIORIDADE & $3^{a}$ PRIORIDADE \\
\hline Jardim Paulista II & $\begin{array}{l}\text { Ampliação do Cemi } \\
\text { (Creche Municipal) } \\
\text { Wenzel e doação do } \\
\text { terreno ao lado }\end{array}$ & $\begin{array}{l}\text { Continuação do } \\
\text { calçadão da Escola } \\
\text { Armando Grisi até a } \\
\text { rua } 28\end{array}$ & $\begin{array}{l}\text { Base comunitária de } \\
\text { segurança da Guarda } \\
\text { Municipal e ou Polícia Militar }\end{array}$ \\
\hline Recanto Paraíso & $\begin{array}{l}\text { Trabalho para jovens } \\
\text { (tipo Projeto } \\
\text { Geração) }\end{array}$ & $\begin{array}{l}\text { Iluminação na rua } 17 \\
\text { avs. } 66 \text { e } 68 \text { e viela } \\
\text { da rua } 18,4315\end{array}$ & $\begin{array}{l}\text { Pronto atendimento } 24 \text { hs. } \\
\text { Oculista e dentista. }\end{array}$ \\
\hline $\begin{array}{l}\text { Jardim das } \\
\text { Paineiras }\end{array}$ & $\begin{array}{l}\text { Construção do Cemi } \\
\text { junto ao Ginásio } \\
\text { Poliesportivo. Rua } \\
27, \text { av. } 60 \text { e } 62 \text { (em } \\
\text { construção) }\end{array}$ & $\begin{array}{l}\text { Construção de uma } \\
\text { rotatória, av. } 64 \text { - } \\
\text { Estrada da } \\
\text { Jacutinga, } \\
\text { identificação através } \\
\text { de placas de bairros. } \\
\text { lluminação com luz } \\
\text { amarela nos bairros. } \\
\text { Construção de uma } \\
\text { "ilha”, ruas } 26 \text { e } 27 \\
\text { av. } 60, \text { para diminuir } \\
\text { os acidentes no local }\end{array}$ & $\begin{array}{l}\text { Aumento de classes na EMEI } \\
\text { (Escola Municipal de Ensino } \\
\text { Infantil)“ Clara Freire", } \\
\text { cobertura da quadra e } \\
\text { manutenção da piscina com } \\
\text { um motor visando a } \\
\text { prevenção da dengue }\end{array}$ \\
\hline Jardim Panorama & $\begin{array}{l}\text { Construção, sede da } \\
\text { Associação de } \\
\text { Moradores, PETI } \\
\text { (Programa de } \\
\text { Erradicação do } \\
\text { Trabalho Infantil), } \\
\text { base da polícia } \\
\text { comunitária na rua } \\
24 \text { com avenida } 64\end{array}$ & $\begin{array}{l}\text { Construção do } \\
\text { emissário ligando o } \\
\text { esgoto do bairro ao } \\
\text { ETE (Estação de } \\
\text { Tratamento de } \\
\text { Esgotos) Flores }\end{array}$ & $\begin{array}{l}\text { Construção de calçadão e } \\
\text { arborização paralela a linha } \\
\text { férrea interligando os bairros } \\
\text { Rec. Paraíso, Panorama, } \\
\text { Paineiras. }\end{array}$ \\
\hline Jardim Wenzel & $\begin{array}{l}\text { Ampliação da creche } \\
\text { do Wenzel com a } \\
\text { doação do terreno ao } \\
\text { lado }\end{array}$ & $\begin{array}{l}\text { Continuação do } \\
\text { calçadão Armando } \\
\text { Grisi até a rua } 28\end{array}$ & $\begin{array}{l}\text { Segurança comunitária de } \\
\text { Guarda Municipal ou Polícia } \\
\text { Militar }\end{array}$ \\
\hline $\begin{array}{l}\text { Jardim Matheus } \\
\text { Manieiro }\end{array}$ & $\begin{array}{l}\text { Imobiliária Elo que } \\
\text { administra casas } \\
\text { abandonadas tem } \\
\text { que cercar as casas } \\
\text { na av. Saburo } \\
\text { Akamine na altura do } \\
n^{\circ} 986 \text { no Matheus } \\
\text { Manieiro. Vândalos } \\
\text { invadem as casas. }\end{array}$ & Policiamento urgente & $\begin{array}{l}\text { Fazer limpeza no terreno do } \\
\text { antigo asilo na estrada de } \\
\text { Batovi. }\end{array}$ \\
\hline Jardim Santa Eliza & $\begin{array}{l}\text { Transporte escolar } \\
\text { para alunos do } \\
\text { Armando Grisi e } \\
\text { EMEI (Escola } \\
\text { Municipal de Ensino } \\
\text { Infantil) Clara F. } \\
\text { Castellano }\end{array}$ & $\begin{array}{l}\text { Centro Comunitário } \\
\text { com área de lazer } \\
\text { (quadra, play-ground) } \\
\text { e salão para } \\
\text { realização de } \\
\text { projetos em geral }\end{array}$ & $\begin{array}{l}\text { Cursos profissionalizantes } \\
\text { que visem a geração de } \\
\text { emprego e renda, a exemplo } \\
\text { do Consulado da Mulher. }\end{array}$ \\
\hline
\end{tabular}



em Rio Claro/SP.

\begin{tabular}{|l|l|l|l|}
\hline Jardim Cidade Azul & $\begin{array}{l}\text { Limpezas de } \\
\text { sarjetas, carpinas } \\
\text { laterais das sarjetas, } \\
\text { limpezas de terrenos } \\
\text { baldios com remoção } \\
\text { de lixos e entulhos } \\
\text { jogados pelos } \\
\text { moradores }\end{array}$ & $\begin{array}{l}\text { Capeamento de } \\
\text { buracos no asfalto }\end{array}$ & $\begin{array}{l}\text { Construção ou melhoramento } \\
\text { na praça da avenida 66 com } \\
\text { ruas 12 e 13 }\end{array}$ \\
\hline Parque Universitário & $\begin{array}{l}\text { Pronto atendimento } \\
24 \text { horas }\end{array}$ & $\begin{array}{l}\text { Mais policiamento. } \\
\text { Posto policial }\end{array}$ & $\begin{array}{l}\text { Ampliar mais salas de aulas } \\
\text { nesta escola }\end{array}$ \\
\hline
\end{tabular}

REGIÃO 9 - NOROESTE

\begin{tabular}{|c|c|c|c|}
\hline BAIRRO & 1 $^{\text {a }}$ PRIORIDADE & $2^{a}$ PRIORIDADE & $3^{a}$ PRIORIDADE \\
\hline $\begin{array}{l}\text { Jardim Boa Vista } \\
\text { (Nosso Teto) }\end{array}$ & $\begin{array}{l}\text { Construção do novo } \\
\text { prédio do Centro } \\
\text { Municipal de } \\
\text { Convivência Amor e } \\
\text { Paz. }\end{array}$ & $\begin{array}{l}\text { Limpeza do córrego } \\
\text { do Nosso Teto, } \\
\text { arborização para a } \\
\text { melhoria do meio } \\
\text { ambiente. }\end{array}$ & $\begin{array}{l}\text { Construção de um Centro } \\
\text { Comunitário no Jd Boa Vista } \\
\text { para: Encontro da } 3^{\mathrm{a}} \text { idade, } \\
\text { Pastoral da Criança, Posto } \\
\text { Policial, Clube de Mães e } \\
\text { outras atividades }\end{array}$ \\
\hline Jardim Araucária & $\begin{array}{l}\text { Regularização dos } \\
\text { lotes e galerias de } \\
\text { águas pluviais }\end{array}$ & $\begin{array}{l}\text { Áreas de lazer: } \\
\text { campo de futebol } \\
\text { com gramado e } \\
\text { Centro Comunitário }\end{array}$ & $\begin{array}{l}\text { Na impossibilidade de } \\
\text { asfalto, guias e sarjetas no } \\
\text { mínimo } \\
\text { OBS: Aumento de salas de } \\
\text { aula na EMEI (Escola } \\
\text { Municipal de Ensino Infantil) } \\
\text { Clara Freire (solicitação feita } \\
\text { pelos participantes da } \\
\text { reunião da Reg. 8) }\end{array}$ \\
\hline Jardim São João & $\begin{array}{l}\text { Construção de uma } \\
\text { quadra de esportes } \\
\text { coberta na EMEI } \\
\text { Mitiko Nevoeiro }\end{array}$ & $\begin{array}{l}\text { EJA (Educação de } \\
\text { Jovens e Adultos) } 2 \\
\text { de } 5^{\mathrm{a}} \text { a } 8^{\mathrm{a}} \text { na Mitiko. } \\
\text { Ampliação do projeto } \\
\text { Acolher e construção } \\
\text { de outro }\end{array}$ & $\begin{array}{l}\text { Mais segurança nos bairros } \\
\text { São Caetano e São João }\end{array}$ \\
\hline Jardim São Caetano & $\begin{array}{l}\text { Colocar gramado no } \\
\text { rapadão do São } \\
\text { Caetano, av M-25 } \\
\text { com rua } 8 \text {, com } \\
\text { quadra nas laterais }\end{array}$ & $\begin{array}{l}\text { Dotar de iluminação a } \\
\text { praça da av. M-25 } \\
\text { com rua } 8\end{array}$ & $\begin{array}{l}\text { Colocar calçada e iluminação } \\
\text { no trecho da rua } 10 \text { com avs. } \\
\text { M-31 e M-33 - São João }\end{array}$ \\
\hline Jardim Azul & Lombada na rua 3 & Lombada na rua 4 & \\
\hline Parque São Jorge & $\begin{array}{l}\text { Colocar calçada no } \\
\text { trecho da av. M-37 e } \\
\text { M-39 da rua } 11 \text { até a } \\
\text { rua } 6\end{array}$ & $\begin{array}{l}\text { Construir escola no } \\
\text { Jd das Flores na av. } \\
\text { M-51, com ensino } \\
\text { fundamental noturno, } \\
\text { de } 5^{\text {a a }} 8^{\text {a }} \text { série }\end{array}$ & Posto da Guarda Municipal \\
\hline
\end{tabular}



em Rio Claro/SP.

\begin{tabular}{|c|c|c|c|}
\hline Jardim São José & $\begin{array}{l}\text { Construção de } \\
\text { alambrado na } \\
\text { extensão dos muros } \\
\text { das casas e ao redor } \\
\text { da rua, na parte do } \\
\text { campo do São José } \\
\text { (área de lazer) }\end{array}$ & \begin{tabular}{|l|} 
lluminação das 2 \\
vielas do São José \\
(pelo menos 3 postes \\
de luz em cada viela). \\
Objetivo é inibir a \\
marginalidade
\end{tabular} & $\begin{array}{l}\text { Implantação de uma Horta } \\
\text { Comunitária no terreno que } \\
\text { dá fundos no Centro } \\
\text { Comunitário do Jd São José, } \\
\text { em parceria com a } \\
\text { comunidade }\end{array}$ \\
\hline Jardim das Flores & $\begin{array}{l}\text { Passarela para ligar a } \\
\text { av. M-59 do Jd das } \\
\text { Flores com a av. } 84 \\
\text { no Santa Maria }\end{array}$ & $\begin{array}{l}\text { Ampliação do Centro } \\
\text { Comunitário do } \\
\text { Flores para atender } \\
\text { mais crianças no } \\
\text { Projeto Acolher }\end{array}$ & $\begin{array}{l}\text { Verba para criar cursos no } \\
\text { Centro de Convivência do } \\
\text { Flores }\end{array}$ \\
\hline Jardim Progresso & $\begin{array}{l}\text { Continuação das } \\
\text { galerias até o término } \\
\text { dos serviços, guias e } \\
\text { sarjetas }\end{array}$ & $\begin{array}{l}\text { Galerias, guias e } \\
\text { sarjetas }\end{array}$ & $\begin{array}{l}\text { Regulamentação da rede de } \\
\text { esgoto das avs. } 52 \text { e } 53\end{array}$ \\
\hline $\begin{array}{l}\text { Conjunto } \\
\text { Habitacional } \\
\text { Recanto Verde }\end{array}$ & $\begin{array}{l}\text { Construção do novo } \\
\text { prédio do Centro de } \\
\text { Convivência Amor e } \\
\text { Paz }\end{array}$ & $\begin{array}{l}\text { Limpeza do córrego } \\
\text { do Nosso Teto, } \\
\text { arborização para a } \\
\text { melhoria do meio } \\
\text { ambiente }\end{array}$ & $\begin{array}{l}\text { Construção de um Centro } \\
\text { Comunitário no Jd Boa Vista } \\
\text { para encontro da } 3^{a} \text { Idade, } \\
\text { Pastoral da Criança, Posto } \\
\text { Policial, Clube de Mães e } \\
\text { outras necessidades } \\
\\
\text { OBS: Asfaltar ruas 21, } \\
\text { Estrada da Jacutinga e Pé- } \\
\text { no-chão }\end{array}$ \\
\hline Jardim Santa Maria & $\begin{array}{l}\text { Creche na rua } 14 \\
\text { com av. } 74-\mathrm{Jd} \\
\text { Santa Maria }\end{array}$ & $\begin{array}{l}\text { Fazer um projeto } \\
\text { para tirar as crianças } \\
\text { das ruas. Centro } \\
\text { Comunitário nas ruas } \\
14 \text { e } 15 \text { com av. } 80 \text { e, } \\
\text { fazer um campo de } \\
\text { futebol e parque de } \\
\text { recreação, mas que } \\
\text { seja organizado e } \\
\text { tenha segurança }\end{array}$ & $\begin{array}{l}\text { Aumentar a segurança no } \\
\text { bairro, iluminação pública } \\
\text { atrás das casas pré- } \\
\text { moldadas, pois nesse local já } \\
\text { aconteceram } 3 \text { crimes. } \\
\text { OBS: Ampliação do EJA } \\
\text { (Educação de Jovens e } \\
\text { Adultos) da } 5^{a} \text { a } 8^{a} \text { série já } \\
\text { que existem salas que ficam } \\
\text { vazias a noite no Mitiko }\end{array}$ \\
\hline
\end{tabular}

REGIÃO $10-$ CENTRO I

\begin{tabular}{|l|l|l|l|}
\hline BAIRRO & $1^{\text {a }}$ PRIORIDADE & $2^{\text {a }}$ PRIORIDADE & $3^{\text {a }}$ PRIORIDADE \\
\hline Jardim Karan & Mudança da mão de & Construção de redutor & \\
& direção da av. 52 (rua & de velocidade na rua & \\
& 6 e rua particular) para & 6 com avs. 48 e 50 - & \\
mão dupla & em frente ao CEMI & (Creche Municipal) / & \\
& & EMEl (Escola & \\
& & Municipal de & \\
& & Educação Infantil) & \\
& & \\
\hline
\end{tabular}



em Rio Claro/SP.

\begin{tabular}{|c|c|c|c|}
\hline Jardim Portugal & $\begin{array}{l}\text { Execução da praça - } \\
\text { conclusão como } \\
\text { prioridade iluminação, } \\
\text { segurança, higiene } \\
\text { (acúmulo de lixo) }\end{array}$ & $\begin{array}{l}\text { Pavimentação da } \\
\text { viela - segurança }\end{array}$ & $\begin{array}{l}\text { lluminação da av. } 50 \text { entre } \\
\text { ruas } 6 \text { e } 5 \text { particular - } \\
\text { segurança }\end{array}$ \\
\hline Alto do Santana & $\begin{array}{l}\text { Posto policial (DP) } \\
\text { porque o do Cervezão } \\
\text { está precário. Gestões } \\
\text { para o aumento do } \\
\text { efetivo (Redher Neto) }\end{array}$ & $\begin{array}{l}\text { Grande limpeza em } \\
\text { áreas institucionais } \\
\text { (mato e ratos), } \\
\text { calçadas mal feitas }\end{array}$ & $\begin{array}{l}\text { Esgoto que reflui entre av. } 48 \\
\text { e av. } 40 \text { na rua } 9 \text { e } 10\end{array}$ \\
\hline Vila BNH & $\begin{array}{l}\text { Providencias para } \\
\text { melhor escoamento } \\
\text { de água na Av. Aldo } \\
\text { Callegari }\end{array}$ & $\begin{array}{l}\text { Estudos para } \\
\text { viabilização para } \\
\text { implantação de } \\
\text { semáforo na rua } 11 \\
\text { com av. } 42 \text { e av. Aldo } \\
\text { Callegari }\end{array}$ & \\
\hline Vila Operária & $\begin{array}{l}\text { Sistema de } \\
\text { sinalização no bairro, } \\
\text { contando com a } \\
\text { implementação de } \\
\text { placas e sinalização } \\
\text { de ruas }\end{array}$ & $\begin{array}{l}\text { Arborização urbana, } \\
\text { prioritariamente junto } \\
\text { ao passeio }\end{array}$ & Segurança pública \\
\hline Vila Aparecida & $\begin{array}{l}\text { Volta da EE (Escola } \\
\text { Estadual) "Irineu } \\
\text { Penteado" como } \\
\text { escola de } 2^{\circ} \text { grau }\end{array}$ & $\begin{array}{l}\text { Um posto de } \\
\text { atendimento } \\
\text { municipal com } \\
\text { Guarda Municipal na } \\
\text { praça } 9 \text { de julho, onde } \\
\text { o prédio é da } \\
\text { Prefeitura (antigo } \\
\text { abrigo de ônibus) } \\
\end{array}$ & $\begin{array}{l}\text { Melhor sinalização de trânsito } \\
\text { no bairro }\end{array}$ \\
\hline Jardim Olinda & $\begin{array}{l}\text { Reforma da cozinha } \\
\text { do CEMl (Creche } \\
\text { Municipal) Santo } \\
\text { Antônio }\end{array}$ & $\begin{array}{l}\text { Compra de casinha } \\
\text { de boneca para } 100 \\
\text { crianças do CEMI } \\
\text { Santo Antônio (igual a } \\
\text { da creche do } \\
\text { Palmeiras) }\end{array}$ & $\begin{array}{l}\text { Ampliação de um cômodo } \\
\text { para produtos de limpeza } \\
\text { para o CEMI Santo Antônio }\end{array}$ \\
\hline $\begin{array}{l}\text { Vila Santa } \\
\text { Terezinha }\end{array}$ & $\begin{array}{l}\text { Aumento do efetivo da } \\
\text { Guarda Municipal e } \\
\text { vigias patrimoniais, } 2 \\
\text { viaturas GM e } 1 \\
\text { viatura para os vigias } \\
\text { patrimoniais }\end{array}$ & $\begin{array}{l}\text { Ampliação do Centro } \\
\text { Dia do Idoso, com } \\
\text { construção de mais } \\
\text { salas, galpão e } \\
\text { sanitários, } \\
\text { beneficiando ainda } \\
\text { mais a comunidade }\end{array}$ & $\begin{array}{l}\text { Garantir recursos para cursos } \\
\text { profissionalizantes e geração } \\
\text { de emprego e renda. }\end{array}$ \\
\hline Santana & $\begin{array}{l}\text { Segurança - ronda da } \\
\text { GM nos postos } \\
\text { principais (Unesp, } \\
\text { praças, } \\
\text { supermercados) }\end{array}$ & $\begin{array}{l}\text { Aproveitamento do } \\
\text { terreno anexo à praça } \\
\text { da av. } 30 \text { com rua } 10 . \\
\text { Construção de uma } \\
\text { área cultural e lazer } \\
\text { para apresentações } \\
\text { de teatro, música, } \\
\text { danças, coral, etc. }\end{array}$ & $\begin{array}{l}\text { Coleta de lixo nas praças } \\
\text { (São Judas Tadeu, Santana e } \\
\text { demais) } \\
\text { OBS: Aumento do efetivo da } \\
\text { GM (Guarda Municipal) e } \\
\text { viaturas para dar mais apoio } \\
\text { a comunidade }\end{array}$ \\
\hline
\end{tabular}


REGIÃO 11 - CENTRO II

\begin{tabular}{|c|c|c|c|}
\hline BAIRRO & $1^{\text {a }}$ PRIORIDADE & $2^{\mathrm{a}}$ PRIORIDADE & $3^{a}$ PRIORIDADE \\
\hline Consolação & $\begin{array}{l}\text { Construção do SESC } \\
\text { (Serviço Social do } \\
\text { Comércio) }\end{array}$ & $\begin{array}{l}\text { Segurança - mais } \\
\text { Guardas Municipais, } \\
\text { trabalhar mais a } \\
\text { organização de } \\
\text { trânsito. Ex.: Carros } \\
\text { que ficam nas } \\
\text { calçadas }\end{array}$ & $\begin{array}{l}\text { Limpeza de terrenos (Lei), } \\
\text { construção de calçadas }\end{array}$ \\
\hline $\begin{array}{l}\text { Bairro da Boa } \\
\text { Morte }\end{array}$ & \multicolumn{3}{|c|}{$\begin{array}{l}\text { Troca das árvores da Rua 12, rua } 13 \text { e avenida } 07 . \text { Na av. } 7 \text { há uma árvore } \\
\text { seca em perigo. As que estão na rua } 12 \text { oferecem mais riscos de caírem, } \\
\text { pois quando dá uma chuva com ventania muito forte, elas tombam todas } \\
\text { para o lado da escola, correndo o risco de cair em cima das salas de aula e } \\
\text { machucando crianças, professores e pedestres. Outro problema é a sujeira } \\
\text { nas calhas das casas. Os moradores desse bairro são pessoas de idade e a } \\
\text { cada ventania precisam ficar limpando calhas, subindo em cima dos } \\
\text { telhados. A noite iluminação fica fraca devido o crescimento muito alto das } \\
\text { árvores, fica tudo mal iluminado. }\end{array}$} \\
\hline Zona Central & $\begin{array}{l}\text { Asfaltamento(reparos e } \\
\text { em alguns locais asfalto } \\
\text { novo) }\end{array}$ & $\begin{array}{l}\text { Segurança } \\
\text { (camêras), } \\
\text { principalmente ronda } \\
\text { escolar (próximos a } \\
\text { escolas) }\end{array}$ & $\begin{array}{l}\text { Lazer (aparelho - local } \\
\text { para realizar lazer) } \\
\text { Melhoria dos CSU's } \\
\text { (Centro Social Urbano) } \\
\text { próximos. }\end{array}$ \\
\hline Bairro da Saúde & $\begin{array}{l}\text { Recuperação (depressão) } \\
\text { do asfalto na rua } 4 \text { X av } 9\end{array}$ & $\begin{array}{l}\text { Manutenção das } \\
\text { calçadas intimando } \\
\text { os proprietários a } \\
\text { repara-las }\end{array}$ & $\begin{array}{l}\text { Placa "Proibido Parar" na } \\
\text { av. } 15 \text { ruas } 3 \text { e } 4 \text { e tornar a } \\
\text { av. } 15 \text { rua } 1 \text { até a rua } 9 \\
\text { preferencial. }\end{array}$ \\
\hline
\end{tabular}

REGIÃO 12 - ASSISTÊNCIA

\begin{tabular}{|l|l|l|l|}
\hline BAIRRO & $1^{\text {a }}$ PRIORIDADE & $2^{\text {a }}$ PRIORIDADE & $3^{\text {a }}$ PRIORIDADE \\
\hline Assistência & $\begin{array}{l}\text { Construção da 1 } 1^{\text {a }} \\
\text { escola, creche. } \\
\text { Ensino médio a noite }\end{array}$ & $\begin{array}{l}\text { Asfalto, construção de } \\
\text { via Marginal }\end{array}$ & $\begin{array}{l}\text { Saúde, médico todos os } \\
\text { dias ou PSF (Programa } \\
\text { Saúde da Família) }\end{array}$ \\
\hline
\end{tabular}

REGIÃO $13-A J A P I$

\begin{tabular}{|l|l|l|l|}
\hline BAIRRO & 1 $^{\text {a }}$ PRIORIDADE & 2 $^{\text {a } \text { PRIORIDADE }}$ & 3 ${ }^{\text {a }}$ PRIORIDADE \\
\hline Ajapi & $\begin{array}{l}\text { Nova ambulância para } \\
\text { atender o Distrito }\end{array}$ & $\begin{array}{l}\text { Sala de aula na EMEI } \\
\text { (Escola Municipal de } \\
\text { Educação Infantil). Há } \\
\text { uma classe do Projeto } \\
\text { Esperança que está no } \\
\text { Centro Rural e este } \\
\text { não tem estrutura para } \\
\text { acolher este tipo de } \\
\text { atividade. }\end{array}$ & $\begin{array}{l}\text { Quadra poliesportiva e } \\
\text { play-ground dentro do } \\
\text { Centro Rural. }\end{array}$ \\
& $\begin{array}{l}\text { OBS: Divulgação da } \\
\text { programação da } \\
\text { Biblioteca móvel } \\
\text { (ônibus). Estudar } \\
\text { viabilidade do passe- } \\
\text { biblioteca, ou seja, } \\
\text { jovens dos distritos } \\
\text { receberem passe para ir } \\
\text { à biblioteca do Centro } \\
\text { Cultural. }\end{array}$ \\
\hline
\end{tabular}


REGIÃO $14-F E R R A Z$

\begin{tabular}{|c|c|c|c|}
\hline BAIRRO & $1^{\text {a }}$ PRIORIDADE & $2^{a}$ PRIORIDADE & $3^{\mathrm{a}}$ PRIORIDADE \\
\hline Ferraz & $\begin{array}{l}\text { Reforma do Centro } \\
\text { Comunitário com } \\
\text { retirada do campo de } \\
\text { bocha e construção de } \\
\text { um novo campo } \\
\text { coberto fora do salão } \\
\text { para, desta forma, } \\
\text { aumentar o espaço no } \\
\text { salão. }\end{array}$ & $\begin{array}{l}\text { Projeto para término } \\
\text { das galerias, guias e } \\
\text { sarjetas e asfalto nas } \\
\text { ruas que faltam. }\end{array}$ & $\begin{array}{l}\text { Aumento do efetivo da } \\
\text { Guarda Municipal, com } \\
\text { viatura equipada e posto da } \\
\text { GM em Ajapi para atender } \\
\text { Ferraz. } \\
\text { OBS: Ginástica para } \\
\text { senhoras no Centro } \\
\text { Comunitário. Cursos de } \\
\text { pintura, costura, etc }\end{array}$ \\
\hline
\end{tabular}

REGIÃO $15-B A T O V I$

\begin{tabular}{|l|l|l|l|}
\hline BAIRRO & $1^{\text {a }}$ PRIORIDADE & $2^{\text {a }}$ PRIORIDADE & $3^{\text {a }}$ PRIORIDADE \\
\hline Batovi & $\begin{array}{l}\text { Apoio a regularização } \\
\text { da terra. }\end{array}$ & $\begin{array}{l}\text { Intensificação de } \\
\text { patrulhamento pela } \\
\text { Guarda Municipal e } \\
\text { solicitar para a PM } \\
\text { (Polícia Militar) maior } \\
\text { segurança }\end{array}$ & $\begin{array}{l}\text { Formação de grupo de } \\
\text { ginástica feminina. }\end{array}$ \\
& & & \\
& & & \\
& & & \\
\hline
\end{tabular}

REGIÃO $16-I T A P E ́$

\begin{tabular}{|c|c|c|c|}
\hline BAIRRO & $1^{\text {a }}$ PRIORIDADE & 2 $^{\mathrm{a}}$ PRIORIDADE & 3a PRIORIDADE \\
\hline Itapé & $\begin{array}{l}\text { Conserva de estrada, } \\
\text { quando chove entope as } \\
\text { bocas de lobo. } \\
\text { Queremos um } \\
\text { funcionário que fique } \\
\text { permanentemente em } \\
\text { Itapé para serviços } \\
\text { gerais. Cascalhamento } \\
\text { da via principal } \\
\text { (aproximadamente } 150 \\
\text { metros) }\end{array}$ & $\begin{array}{l}\text { Coleta de lixo. Como } \\
\text { acontece no bairro } \\
\text { Jacutinga, existe um } \\
\text { coletor de lixo coletivo } \\
\text { e passam pra pegar o } \\
\text { lixo uma vez por } \\
\text { semana. }\end{array}$ & $\begin{array}{l}\text { Iluminação no campo de } \\
\text { futebol. } \\
\text { OBS: Criação da Secretaria } \\
\text { da Agricultura, conforme } \\
\text { aprovado na } 2^{\text {a }} \text { Conferência } \\
\text { da Cidade }\end{array}$ \\
\hline
\end{tabular}

REGIÃO 17 - SUDOESTE II

\begin{tabular}{|l|l|l|l|}
\hline BAIRRO & $1^{\text {a }}$ PRIORIDADE & $2^{\text {a }}$ PRIORIDADE & $3^{\text {a PRIORIDADE }}$ \\
\hline Novo Jardim Wenzel & $\begin{array}{l}\text { Creche junto com } \\
\text { EMEI (Escola } \\
\text { Municipal de } \\
\text { Educação Infantil) }\end{array}$ & $\begin{array}{l}\text { Centro Comunitário } \\
\text { com salão para } \\
\text { atividades de saúde e } \\
\text { área de lazer }\end{array}$ & $\begin{array}{l}\text { Aumento de duas salas no } \\
\text { Projeto Pai (Projeto de } \\
\text { Alfabetização e Inclusão) }\end{array}$ \\
\hline Jardim Bonsucesso & $\begin{array}{l}\text { Recurso para preparo } \\
\text { de geração de } \\
\text { emprego e renda }\end{array}$ & $\begin{array}{l}\text { Ampliação da escola } \\
\text { "Prof. Luiz Martins } \\
\text { Rodrigues Filho" }\end{array}$ & Centro Comunitário \\
\hline
\end{tabular}

Observação: A redação das prioridades foi mantida, conforme documento fornecido pela Prefeitura Municipal de Rio Claro. Acrescentamos somente o significado das siglas/abreviações 

em Rio Claro/SP.

Na região 1, que na análise realizada com base nos mapas da cidade, se apresentou como contrastante, pois revelou um espaço formado desigualmente e onde encontramos bairros ocupados por população de baixos rendimentos e bairros ocupados por população com rendimentos superiores. Podemos identificar que os bairros Mãe Preta e Vila Industrial reivindicam obras básicas para a reprodução da vida, ligadas à melhorias na saúde e na infra-estrutura (asfalto). Essas reivindicações indicam que nem sempre os loteamentos que recebem a população encontram-se em condições para isso, ou que não estavam preparados para abrigar um número tão elevado de pessoas. Destaca-se nas reivindicações da região a necessidade de implantação de equipamentos de lazer e esportes, apontando uma preocupação com o futuro das crianças e jovens da região, que não tem local para práticas lúdicas, o que preocupa pais e moradores. Os bairros, Residencial Florença e Vila Verde, que tem população com maiores rendimentos, de classe média e alta, apresentam reivindicações, principalmente, ligadas à circulação e trânsito. $O$ Residencial Florença apresenta uma demanda por rede de esgoto, pois como a área foi loteada para receber chácaras, este equipamento não foi implantado.

A região 2 caracteriza-se por ser constituída, principalmente, por bairros operários e que foram implantados até 1970. As reivindicações concentram-se nos pedidos de galerias, asfalto e melhorias de asfalto, pois há bairros que já possuem essa benfeitoria, porém como não existe manutenção contínua, ele se encontra deteriorado em alguns locais. Destacam-se também os pedidos para melhoramentos e adaptações nas linhas de ônibus, pois a população depende do transporte coletivo para se locomover; e a preocupação com atividades esportivas, profissionalizantes e de lazer para as crianças e adolescentes. É apontado nas prioridades do bairro Residencial Orestes Armando Giovanni o problema de regularização do loteamento, isto porque este bairro que foi implantado pela própria prefeitura municipal, na gestão 1992-1996, através do projeto denominado Pé no Chão, não é regularizado. $\mathrm{O}$ bairro se encontra em área da Floresta Estadual e é irregular, pois se trata de área invadida ilegalmente. Nos bairros Jardim América e Jardim Ipê, por se configurarem como bairros mais estruturados, os pedidos são referentes a melhoramentos paisagísticos e a segurança pública.

Com exceção do bairro Jardim Floridiana, que tem suas prioridades referentes a circulação do trânsito e paisagismo, na região 3 concentram-se reivindicações ligadas à geração de emprego e renda, educação e acolhimento de 

em Rio Claro/SP.

crianças e adolescentes em horário extra curricular. Nesta região há reivindicações de galerias e asfalto, mas em número reduzido, pois a área já conta com esta benfeitoria. Analisando as prioridades podemos reafirmar o que expusemos, anteriormente com relação a identidade que foi criada nesta região com o bairro Cervezão, pois há reivindicações dos bairros bastante parecidas e até mesmo iguais.

$\mathrm{Na}$ região 4, que é uma região ocupada por uma população com altos rendimentos, as reivindicações concentram-se nos pedidos ligados, principalmente, a melhorias paisagísticas e de áreas de lazer e esporte. Nos bairros Bela Vista e Cidade Nova aparecem pedidos referentes a melhoras nas escolas municipais dos bairros. Os bairros Vila Paulista e, particularmente, Jardim Conduta, que agregam população mais carente, apresentam pedidos mais essenciais ligados à saúde básica, o que revela que esta população carece e necessita deste serviço público.

As reivindicações relacionadas à manutenção dos bairros da cidade são destaque na região 5. A exceção é o bairro do Estádio, que solicita, assim como, o Jardim Quitandinha, quadra de esportes para a escola e creche. Os dois bairros citados são os que apresentam menores rendimentos entre a população da região. Os demais bairros preocupam-se com limpeza, manutenção e segurança da cidade.

A região 6 teve a participação de moradores de nove bairros. As reivindicações são bastante variadas e tem estreita relação com condições mínimas para a prática da vida cotidiana. Os pedidos que se destacam são os de criação de cooperativas e cursos profissionalizantes para geração de emprego e renda; galerias e asfalto, já que muitos bairros desta região ainda não o possuem; áreas de lazer, esporte e centros comunitários para encontro dos moradores. Há também pedidos de iluminação, ampliações e reformas de creches e escolas. Essa ampla gama de reivindicações revela uma região carente e com grande falta de infra-estrutura e serviços públicos coletivos.

Embora a região 7 abrigue população com médios rendimentos que vivem em bairros com grandes e luxuosos imóveis, verificamos através das reivindicações apresentadas no OP 2004 que, muitas vezes, esses bairros não possuem asfalto. É o caso, por exemplo, dos bairros Jardim São Paulo I e II. Nesta região se destaca muito os pedidos por galerias de águas pluviais e asfalto, o que revela que nem sempre áreas ocupadas por população da classe média possuem toda a sorte de infra-estrutura e serviços urbanos. Essa região que é grande territorialmente 

em Rio Claro/SP.

apresenta problemas ligados a córregos que passam pelos bairros e, por isso, há um número razoável de pedidos de canalização e urbanização destes. Há também pedidos por iluminação, centros comunitários e linhas de ônibus, pois alguns bairros transpõem a rodovia Washington Luiz e são bastante distantes da área central da cidade.

A região 8 também se caracteriza pela variedade de tipos de reivindicações. Observamos a incidência de pedidos por criação e ampliação de creches, pois as mães têm que trabalhar e não tem onde deixar suas crianças, que ainda não estão em idade escolar. Existem também pedidos ligados à geração de emprego e renda, o que revela uma população que, muitas vezes, não tem como se sustentar e sustentar sua família. Os pedidos de segurança pública, embora este ítem não seja competência municipal, aparecem em diversos bairros, revelando existência de problemas de violência na região e a preocupação com a segurança dos moradores, que é dificultada, ainda mais, pela falta de iluminação. Aparecem também, nesta região, diversos pedidos de limpeza e manutenção de áreas públicas e postos de saúde abertos 24 horas.

Como a região 9 é bastante carente e estiveram presentes, na reunião do $\mathrm{OP}$, moradores de todos os 11 bairros que a compõem, a quantidade e variedade de reivindicações desta região é enorme. O elenco de reivindicações revela um espaço desprovido de infra-estrutura básica como galerias de águas pluviais, asfalto, iluminação e equipamentos públicos de educação, pois há muitos pedidos por creches, escolas, educação para jovens e adultos. Existem também pedidos para a instalação de centros comunitários, o que mostra a falta de espaços para a população se encontrar e realizar atividades sociais e também a participação das associações de moradores que reivindicam lugares para se instalar e estabelecerem suas atividades. A reivindicação expressiva por segurança manifesta a preocupação destas pessoas com problemas de violência, ligada ao tráfico de drogas, que essa população enfrenta diariamente. O Jardim Araucária, assim como, o Residencial Orestes Armando Giovanni, da região 3, faz parte do projeto municipal Pé no Chão, que construiu moradias populares em áreas irregulares e, por isso, os moradores pedem regularização dos lotes.

A região 10 que se caracteriza por abrigar população de classe média e por ser uma região de ocupação antiga e já estruturada apresenta em suas prioridades pedidos relacionados à manutenção da cidade, de maneira geral. Aparecem pedidos 

em Rio Claro/SP.

ligados ao trânsito, sinalização de ruas, coleta de lixo, melhoramento de áreas verdes, segurança, adequação de iluminação. Destaca-se o bairro Jardim Olinda, pois neste bairro houve organização de funcionários e mães de usuários da creche e, por isso, todas as reivindicações estão ligadas à melhoria deste equipamento.

Na região 11 os pedidos relacionados a manutenção da cidade estão ainda mais evidentes. É pedida também efetivação da segurança na área central e manutenção e troca de asfaltos. Os pedidos relacionados a lazer também estão presentes.

É necessário observar que as reivindicações das regiões 10 e 11 estão ligadas as questões de manutenção e não de investimentos, que é o verdadeiro foco das discussões do OP. Isto acontece porque a população utiliza esta abertura dada pela administração municipal para fazer suas reivindicações e, como essas regiões já são providas de toda infra-estrutura e serviços públicos, as reivindicações ficam no plano das manutenções.

A região 17 é formada por dois bairros apenas. Embora, estes bairros não possuíssem asfalto e galerias e a iluminação fosse precária, até o dia da reunião, os pedidos feitos pela população se concentram na área da educação, creche e ampliação da escola; centros comunitários e programas para geração de emprego e renda. O que mostra a necessidade desta população trabalhar para aumentar a renda familiar e a preocupação com a educação de crianças, jovens e adultos.

Embora não seja nosso objeto de estudo, analisando as reivindicações dos distritos e vila rural, que são as regiões do OP que não fazem parte da área urbana, verificamos que os pedidos têm estreita ligação com os pedidos da área urbana, com destaque, para ampliação dos serviços de saúde, educação, melhoria na segurança e construção de centros comunitários.

$\mathrm{O} \mathrm{OP}$, em um segundo momento, propunha um desafio aos moradores dos bairros, que era a discussão regional. Cada região, que era formada por um conjunto de aproximadamente 10 bairros, reunia os moradores destes diversos bairros e discutiam seus problemas. Esta discussão regional revelou conflitos entre os seus moradores, pois cada morador defendia o seu espaço, o seu lugar de indentidade, que é o espaço do seu bairro e que contém, ou devem conter, as condições imediatas para a reprodução da vida, a partir do lugar de moradia. Trazer ao morador a discussão regional, de um espaço mais amplo e coletivo, embora não se trate aqui de toda a cidade, mas sim de uma parcela dela, revela a possibilidade de 

em Rio Claro/SP.

conhecimento, por parte do habitante dessa região, de um espaço ampliado daquele com o qual ele se identifica, porque o usa. O morador, participante da reunião, tem que ampliar sua visão do espaço urbano para que possa decidir qual a questão mais importante a ser realizada para o desenvolvimento da região, como um todo, e não só da sua rua, do seu bairro. Nesse momento a "caravana do OP", realizada com alguns participantes do processo, possuía um papel fundamental, pois ela mostrava aos conselheiros, claramente, quais seriam as prioridades levantadas pelas regiões e qual a situação de cada uma delas. Além de um processo de sensibilização dos participantes a caravana possibilitava um conhecimento da cidade e/ou da região. Os moradores que tinham a identidade construída somente no seu bairro, na sua rua, podiam ampliar essa visão conhecendo um pouco mais o território onde viviam.

A discussão da cidade, como um território único, não era colocada durante as reuniões do OP em Rio Claro/SP. Eram sempre discussões que tratavam apenas da região. O planejamento e desenvolvimento da cidade como um todo, não apareciam, nas discussões do OP. Apenas em alguns momentos eram levantadas questões que diziam respeito a toda a cidade, como a questão da segurança, por exemplo.

As reuniões do OP não discutiam a cidade como um todo, mas apenas partes da cidade (regiões), o que revelava uma fragmentação, que não necessariamente obedeciam aos limites estabelecidos pela prefeitura. A questão que se coloca é: a discussão dessas regiões interferia no planejamento da cidade como um todo? Antes da implantação do Orçamento Participativo em Rio Claro/SP as obras da cidade eram discutidas apenas em gabinete pelos políticos e técnicos da administração municipal. A partir de então, não são mais eles sozinhos que decidiam tudo. Passa a haver uma participação popular, que embora comandada pelo Estado, opinava e apontava questões próprias que os afetavam na sua vida cotidiana e que não podiam ser ignoradas.

As discussões regionais revelavam a segregação e a desigualdade urbana que se acentua com a privatização de serviços e de infra-estrutura, bem como a redução das despesas públicas junto aos serviços sociais. Como o espaço é produto das relações sociais, na medida em que há uma fragmentação da sociedade, com diferenciação da distribuição social dos serviços, ocorre também a fragmentação do espaço urbano Essa fragmentação é social e espacial. Com ela há uma dissolução das relações sociais até mesmo na família. 
Embora em um primeiro momento a cidade possa parecer como um só território, com uma análise crítica podemos diferenciar paisagens e realidades bastante diversas. Essa diferenciação dos lugares da cidade se dá por sua característica de construção histórica e social, mas, além disso, encontramos também a influência e a dominação do capital que, agindo em sua lógica, transforma a cidade em um campo para o jogo comercial, onde os lugares que possuem estrategicamente características de interesse ao capital, próximo de centros comerciais, como a acessibilidade, por exemplo, recebe tratamento diferenciado de outras áreas. Nos referimos aqui principalmente na implantação de infra-estrutura. Nesse campo de forças atuam diferentes "jogadores", com interesses ora diferentes, ora semelhantes. Os principais jogadores são os loteadores, agentes imobiliários e o Estado, que em algumas situações possuem os mesmos objetivos e em outras não, mas o que ocorre é que o jogo acontece entre esses jogadores e a sociedade, principalmente aquela de menor poder aquisitivo, assiste tudo de longe, como mero espectador.

Com relação as solicitações que ocorriam durante as reuniões regionais, elas dizem respeito à questões ligadas a inúmeros temas. Podemos destacar as questões ligadas à educação, saúde, saneamento básico, pavimentação (galerias e asfalto), convívio social e qualificação profissional. São geralmente, solicitações de construções e ampliações de escolas e postos de saúde; construção de centros comunitários; implantações de galerias e asfalto e realização de cursos profissionalizantes, solicitação essa que é fruto de discussões sobre desemprego e qualificação profissional.

A seguir, apresentamos um quadro que mostra as prioridades selecionadas pelo Conselho do Orçamento Participativo para o ano de 2004 e os valores destinados para realização destas. Estas prioridades foram selecionadas dentre aquelas anteriormente apresentadas, que referiam-se aos bairros da cidade. Visualiza-se parcialmente o resultado do "jogo" da especulação e a alternativa encontrada por parte da população, que tenta amenizar as conseqüências negativas que são produto da produção desigual do espaço. 
Quadro 2 - Destinação Final da Verba do Orçamento Participativo 2004

\begin{tabular}{|c|c|c|}
\hline Região & Obras & Valor destinado \\
\hline 1 & $\begin{array}{l}\text { Acostamento da rua dos Estudantes, de um só lado da pista, sem } \\
\text { galerias, até a Rodovia. }\end{array}$ & $\mathrm{R} \$ 300.000,00$ \\
\hline 2 & $\begin{array}{l}\text { Construção de galerias na avenida 64-A - São Miguel, para } \\
\text { acabar com problema de enchentes na área atrás da escola } \\
\text { Ephraim, Posto de Saúde Vila Cristina, Centro de Reabilitação. } \\
\text { Com o compromisso da Prefeitura, juntamente com a } \\
\text { comunidade, colocar o asfalto na avenida Joaquim Ribeiro ligando } \\
\text { a rua 6-A e 7-A. }\end{array}$ & $\mathrm{R} \$ 300.000,00$ \\
\hline 3 & Quadra da EMEIF Victorino Machado (quadra coberta) & $\mathrm{R} \$ 150.000,00$ \\
\hline 4 & $\begin{array}{l}\text { Ampliação da parte administrativa da EMEI Benjamin Ferreira, } \\
\text { com a construção de um pátio coberto com iluminação para } \\
\text { atividades. }\end{array}$ & $\mathrm{R} \$ 120.000,00$ \\
\hline 5 & $\begin{array}{l}\text { Tubulação de águas pluviais (galeria meia cana) na rua Marginal } \\
\text { da Fepasa, da av } 29 \text { até, se possível, com conexão da galeria da } \\
\text { rua } 6 \text {. Esta tubulação será aberta (não é galeria), margeando a } \\
\text { linha férrea da Ferroban. }\end{array}$ & $\mathrm{R} \$ 100.000,00$ \\
\hline 6 & $\begin{array}{l}\text { Escola no Jardim Novo I com espaço para realização das reuniões } \\
\text { da Associação de Moradores (verba terá que ser complementada } \\
\text { com verba da Secretaria de Educação) }\end{array}$ & $\mathrm{R} \$ 160.000,00$ \\
\hline 7 & $\begin{array}{l}\text { Passagem da Castelo Branco e galerias do Jd Paulista I (terá que } \\
\text { ser complementado com verba da Secr. de Obras) }\end{array}$ & $\mathrm{R} \$ 200.000,00$ \\
\hline 8 & $\begin{array}{l}\text { Centro Comunitário junto ao conjunto poliesportivo (com sala para } \\
\text { a associação de bairro e instalações para o programa PETI) }\end{array}$ & $\mathrm{R} \$ 100.000,00$ \\
\hline 9 & $\begin{array}{l}\text { Construção de galerias, guias e sarjetas no Jd Progresso (para } \\
\text { resolver, inicialmente, o problema principal da avenida 22) }\end{array}$ & $\mathrm{R} \$ 100.000,00$ \\
\hline 10 & $\begin{array}{l}\text { Ampliação do Centro Dia do Idoso, com construção de mais salas, } \\
\text { galpão e sanitários, beneficiando ainda mais a comunidade. }\end{array}$ & $\mathrm{R} \$ 80.000,00$ \\
\hline 11 & $\begin{array}{l}\text { Aumento do efetivo e circulação de guardas municipais e PM } \\
\text { nesta região. Verba para contratação de mais guardas municipais. }\end{array}$ & $\mathrm{R} \$ 33.000,00$ \\
\hline 12 & Construção da $1^{\mathrm{a}}$ escola, creche. & $\mathrm{R} \$ 200.000,00$ \\
\hline 13 & Nova ambulância para atender o Distrito & $\mathrm{R} \$ 60.000,00$ \\
\hline 14 & $\begin{array}{l}\text { Reforma do Centro Comunitário com retirada do campo de bocha } \\
\text { e construção de um novo campo coberto fora do salão para, desta } \\
\text { forma, aumentar o espaço no salão. }\end{array}$ & $R \$ 35.000,00$ \\
\hline 15 & $\begin{array}{l}\text { Apoio a regularização da terra }(\mathrm{R} \$ 10.000,00) \text { e intensificação de } \\
\text { patrulhamento pela Guarda Municipal e solicitar para a PM maior } \\
\text { segurança }(\mathrm{R} \$ 33.000,00) \text { Verba para contratação de mais } \\
\text { guardas municipais. }\end{array}$ & $\mathrm{R} \$ 43.000,00$ \\
\hline 16 & $\begin{array}{l}\text { Cascalhamento da via principal, aproximadamente } 150 \text { metros, } \\
\text { pois já existe canalização das águas pluviais. }\end{array}$ & $\mathrm{R} \$ 20.000,00$ \\
\hline 17 & $\begin{array}{l}\text { Galpão para reunião de moradores, atividades de saúde e área de } \\
\text { lazer para jovens (capoeira e outros eventos) Lugar destinado } \\
\text { dentro do terreno do posto de saúde. }\end{array}$ & $\mathrm{R} \$ 60.000,00$ \\
\hline TOTAL & & R\$ 2.061.000,00 \\
\hline
\end{tabular}

Observação: A redação das prioridades foi mantida, conforme documento fornecido pela Prefeitura

Municipal de Rio Claro. 
Na Plenária geral, quando foram definidas as 3 principais reivindicações por região, observamos que houve uma grande concentração de pedidos ligados à questão de infra-estrutura urbana, principalmente, galerias e asfalto. Das 51 reivindicações das regiões, 39\% referiam-se a pedidos de infra-estrutura, sendo que $35 \%$ dos pedidos de infra-estrutura eram ligados a galerias e asfalto. A reivindicação que aparece em segundo lugar é ligada ao convívio social, ou seja, construção de centros comunitários, espaços para encontros de associações de moradores, reformas de prédios já existentes. Essas reivindicações têm 18\% do total de pedidos feitos pelas regiões. A seguir aparecem a educação com 14\%; geração de emprego e renda com $10 \%$; saúde com $8 \%$; segurança com $5 \%$; regularização de lotes com $4 \%$ e cultura com $2 \%$.

Nas reuniões do OP a questão da infra-estrutura aparece como a mais reclamada pela população, seguido por aquelas ligadas a educação e geração de emprego e renda. Porém aqui, não se trata de uma lógica de valorização de preço do solo, do imóvel urbano, trata-se da necessidade de acesso aos serviços que não são oferecidos naquele lugar, trata-se da reivindicação das condições mínimas para reprodução da vida. Está contido nessa lógica o valor de uso desses instrumentos e não o valor de troca e isso se difere da realidade encontrada nos processos capitalistas que normalmente acontecem na cidade.

Quando analisamos as reivindicações que entraram na peça orçamentária final do orçamento participativo, ou seja, quais foram as reivindicações que o Conselho do Orçamento Participativo considerou de extrema importância para o desenvolvimento da cidade e que atendem as reivindicações feitas nas diversas regiões do município e com possibilidade de realização, percebemos que há uma mudança nos percentuais das reivindicações destinados a cada uma das áreas. Estamos nos referindo ao quadro acima apresentado, que mostra as 17 prioridades finais que formaram a peça orçamentária do OP.

Observamos que a questão de infra-estrutura urbana continua a ser a primeira reivindicação da população apresentando $35 \%$ das 17 prioridades selecionadas. Porém há um crescimento da porcentagem destinada à educação; $23,5 \%$ das 17 reivindicações e $23,5 \%$ ao convívio social, seguida pela segurança com $12 \%$ e saúde com $6 \%$. Porém, se trabalharmos com o valor destinado para cada obra e não pelo número de reivindicações, observamos que o valor, em porcentagem, dessas reivindicações ligadas a infra-estrutura urbana representavam 
$49 \%$ do orçamento disponibilizado para o OP, ou seja, $\mathrm{R} \$ 1.020 .000,00$ orçados para serem gastos com as obras ligadas a infra-estrutura urbana e, $R \$ 630.000,00$ (31\% do valor total) gastos com as reivindicações referentes a educação. As prioridades referentes às questões de infra-estrutura urbana acabam sendo substituídas por outras, devido ao elevado valor de implantação de obras como, pavimentação e galerias pluviais, que ainda ocupam a maior fatia da verba. Há também uma sensibilização por parte dos conselheiros do OP à prioridades referentes a saúde e educação, que ganham um caráter prioritário por se tratar de questões essenciais à vida. Esses dois fatores fazem com que a porcentagem de prioridades ligadas à educação tenha aumentado, em relação, ao quadro geral das prioridades totais, ou seja, aquelas que não entraram para o orçamento final.

A Tabela 7 apresenta o número de reivindicações e as porcentagens e valores orçados em cada temática.

Tabela 7 - Número de reivindicações X Valor Destinado

\begin{tabular}{|c|c|c|c|}
\hline Temas & $\begin{array}{c}\text { Número de } \\
\text { Reivindicações }\end{array}$ & Valor Destinado & $\begin{array}{c}\% \text { do valor } \\
\text { destinado }\end{array}$ \\
\hline Infra-estrutura & 6 & $\mathrm{R} \$ 1.020 .000,00$ & $49 \%$ \\
\hline Educação & 4 & $\mathrm{R} \$ 630.000,00$ & $31 \%$ \\
\hline Convívio Social & 4 & $\mathrm{R} \$ 275.000,00$ & $13 \%$ \\
\hline Segurança & 2 & $\mathrm{R} \$ 76.000,00$ & $4 \%$ \\
\hline Saúde & 1 & $\mathrm{R} \$ 60.000,00$ & $3 \%$ \\
\hline
\end{tabular}

Nota-se que há uma concentração de valores destinados a questão da infraestrutura urbana e a educação. Embora, educação e convívio social tenham o mesmo número absoluto de reivindicações, elas possuem valores muito diferentes destinados às suas obras. Isso acontece porque sempre as reivindicações referentes à educação são priorizadas pelo COP, então, procurou-se destinar uma verba bastante significante para esse tema e também porque equipamentos de educação são mais caros que centros comunitários.

$O$ alto valor destinado às obras de infra-estrutura urbana, especificamente ao asfalto e galerias, explica-se pelo fato destas obras serem maioria absoluta no total de reivindicações feitas pelo OP e, também por se tratarem de obras bastante dispendiosas e que exigem um valor financeiro mais alto. Isto fez com que muitas reivindicações referentes a galerias e asfalto fossem retiradas da pauta, pois caso elas permanecessem e entrassem na peça orçamentária, toda a verba destinada ao 

em Rio Claro/SP.

OP seria gasta em infra-estrutura. A solução encontrada pelos conselheiros foi priorizar as mais emergenciais. A carência de infra-estrutura, revelada pelos inúmeros pedidos de galerias pluviais e asfalto, é ligada à irresponsabilidade de loteadores e também do setor público municipal, que implantaram e autorizaram loteamentos sem o mínimo de infra-estrutura necessário e agora trazem para a administração municipal reivindicações bastante dispendiosas e, muitas vezes, de caráter urgente, devido a problemas de saúde causados pela poeira e as enchentes que ocorriam nestes loteamentos. Esses loteamentos localizam-se na periferia mais distante e são implantados nessas condições para beneficiar proprietários privados, que comercializam moradias e terrenos mais baratos, que são o possível de ser comprado pela população de baixos rendimentos. Isto prejudica estes moradores que passam a viver sem serviços e infra-estrutura básica. Caracterizam-se também por serem ocupados pela população de mais baixos rendimentos, que fica impossibilitada de morar nas regiões centrais e com maior infra-estrutura. A aprovação de loteamentos com baixa ou nenhuma infra-estrutura, por parte da administração municipal, é explicado pela priorização de interesses elitistas dentro da administração pública, que beneficia proprietários e especuladores imobiliários em detrimento da população mais carente que é quem procura esses loteamentos para viver.

Há uma questão que deve ser ressaltada com relação a destinação de verbas para a educação. Durante as reuniões do COP, para definição da destinação de verbas de 2004, ocorreu uma negociação entre os conselheiros do OP e a secretária municipal de educação, isto porque a construção de uma escola, reivindicada pela região 6, estava orçada em $\mathrm{R} \$ 350.000,00$. Um valor alto para obras do OP. Para realizá-la o COP teria que deixar de contemplar outras prioridades não alcançando talvez a execução de uma prioridade por região, que era o objetivo do grupo. Por este motivo os conselheiros iniciaram uma negociação com a secretária de educação para que a secretaria municipal realizasse uma parceria com o OP e disponibilizasse, do orçamento desta secretaria, uma parcela do valor necessário para a construção da escola. Depois de uma discussão entre conselheiros e a secretária municipal de educação ficou decidido que o OP destinaria $\mathrm{R} \$ 160.000,00$ para a construção desta escola, que era uma prioridade muito importante para a região, e a Secretaria Municipal de Educação, complementaria o valor necessário para a realização da obra. Esse fato evidencia que existia uma possibilidade de 

em Rio Claro/SP.

ultrapassar as verbas destinadas ao OP. Eles ajudavam também a destinar parte das verbas de outras secretarias municipais, pois evidenciavam necessidades que a população tinha como prioritária. Logicamente, esta negociação acontecia, desde que houvesse, por parte da secretaria municipal, uma abertura para essa discussão.

Um outro dado que observamos durante a realização das reuniões, nas diversas regiões do Município era uma diferenciação de público e das discussões realizadas nesses encontros. Observamos que, nas regiões periféricas e mais carentes, as reuniões contavam com um número elevado de pessoas e as solicitações referiam-se a pedidos mais emergenciais. Eram solicitações para resoluções de problemas vividos cotidianamente, problemas estes ligados ao mais amplo espectro de questões, sejam eles de educação, saúde, desemprego, infraestrutura urbana, etc.

Já nas regiões centrais e de população com maiores rendimentos a participação era bastante pequena. Havia sempre um número reduzido de pessoas que participavam e, estas áreas já contavam com toda gama de infra-estrutura e serviços ou, muitos dos serviços utilizados por esta população era buscado no setor privado, como escolas particulares e planos de saúde privados. Então, os problemas levantados de modo geral, nas regiões centrais são ligados a questões de manutenção dos serviços já existentes, como limpeza de ruas, praças, segurança, etc. No entanto, haviam discussões realizadas com essas poucas pessoas que compareciam ao convite da Prefeitura, que tinham um caráter mais aprofundado e mais amplo e que diziam respeito à sociedade como um todo. Podemos citar como exemplo, discussões sobre exclusão social, exclusão digital, precarização do trabalho, desemprego, meio ambiente, etc. Problemas esses que não afetavam os moradores dessas regiões diretamente, porém havia uma preocupação com o desenvolvimento da sociedade local como um todo.

De certa forma, esses temas eram levantados em quase todas as regiões, porém nas regiões periféricas a população buscava na Prefeitura uma base para solução imediata de seus problemas emergenciais e nas regiões centrais as discussões buscavam um aprofundamento nas temáticas para encontrar soluções para problemas vividos na cidade a médio e longo prazo. 


\section{Orçamento Participativo e Planejamento}

Apontamos suscintamente neste trabalho o problema referente a questão ligada ao OP e o planejamento geral da cidade, já que esses não se comunicam em nenhum momento do processo. Para a solução desta questão, Souza (2002 p.365), propõe a existência de um só conselho, que seria a junção do OP com o CDU (Conselho de Desenvolvimento Urbano). O objetivo é que planejamento e gestão se unam com o objetivo de alcançar um desenvolvimento equilibrado da cidade.

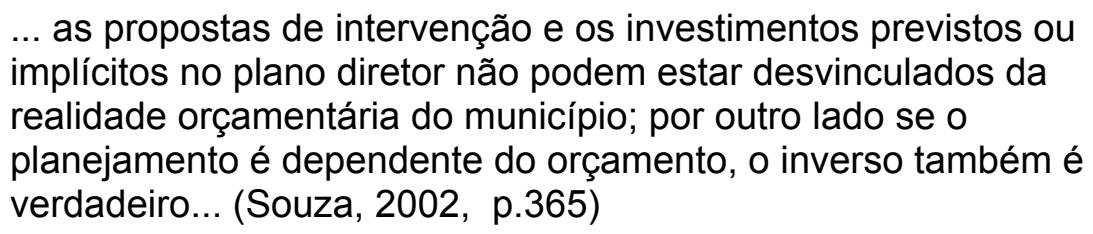

No município de Rio Claro/SP não houve uma integração entre o OP e o planejamento da cidade, o planejamento no que se relaciona ao Plano Diretor, ao PPA (Plano Plurianual) e ao Programa de Governo proposto antes das eleições. Esse fato poderia trazer conseqüências sérias para o futuro de uma cidade como Rio Claro, onde apenas uma parcela dos investimentos era discutida pelo OP. Pudemos visualizar a maneira que trabalhavam o plano diretor e o planejamento, ou seja, com a parcela restante dos investimentos que não foram decididos pelo OP, havendo uma manobra entre os diferentes processos. No entanto, em uma cidade como Porto Alegre/RS, que destina $100 \%$ dos seus investimentos ao OP, não conseguimos compreender como foi trabalhada a questão do planejamento da cidade, pois não há verba destinada para a realização de obras decididas nesse tipo de discussão. Toda ela era definida e destinada pelas prioridades do OP, que soluciona problemas emergenciais da vida das pessoas, mas que não leva em consideração, por exemplo, dados como crescimento populacional, aumento do número de crianças e então a necessidade de aumentar o número de vagas na escola. Não é objeto de nossa pesquisa discutir a experiência de Porto Alegre/RS, porém nos chamou a atenção o modo como foi realizado o trabalho entre planejamento e OP, durante todos os anos de realização do OP em Porto Alegre/RS. Souza (2002) não trata desta questão em seu livro e somente aponta a necessidade de existência de um conselho comum, o que mostra o encontro de uma dificuldade nesse campo.

Em Belém/PA, tomamos conhecimento que a alternativa encontrada pelo então prefeito, Edmilson Brito Rodrigues, foi a extinção do OP e sua substituição 

em Rio Claro/SP.

pelo planejamento participativo, através da Conferência da Cidade, que decidia o futuro de Belém/PA, através de um planejamento em médio prazo e não através de decisões anuais com obras mais emergenciais e com focalização na Lei Orçamentária Anual. Essa alternativa encontrada pela administração de uma cidade que por anos executou o OP mostra que existe uma real dificuldade em projetos que tratam da discussão pública do orçamento anual, que atende problemas imediatos, mas que não tem em consideração o crescimento e desenvolvimento futuro da cidade.

Sobre a questão de gestão e planejamento, Pintaudi (2005 p. 7) analisa as Conferências Municipais ocorridas na cidade de Rio Claro e conclui:

De outra parte, ainda que seja um importante instrumento de gestão, é necessário que obtenha uma transcendência maior que as simples demandas de reprodução imediata da vida. Há que projetar-se à um tempo mais longo, se trata de efetivamente conceber um projeto de futuro, para que se consiga efetividade como instrumento de gestão. O que está no plano da simples reprodução da vida, se encontra em um plano muito restrito, que é visto muito mais do ponto de vista individual que coletivo.

Concordamos com Pintaudi (2005) e afirmamos que o ideal seria que as discussões coletivas do OP e demais instrumentos de participação popular, como são as conferências, tratassem de questões ligadas ao futuro coletivo da cidade. Embora a experiência de Belém seja diferente do proposto por Pintaudi (2005), esta mudança revelou que somente o processo do OP não estava suprindo as necessidades da cidade. Porém em bairros e regiões onde as condições mínimas para a reprodução da vida não estão presentes, como podemos demandar à essas pessoas que discutam sobre o futuro de sua cidade? Logicamente, as questões ligadas à reprodução da vida imediata são as que surgiriam durante os debates públicos, porque elas são emergenciais e fazem parte do cotidiano dessa população. Se, por exemplo, a população não tem um sistema de educação básica público de qualidade, como podem pensar sobre a necessidade de lutar para a instalação de um campus universitário público na cidade?

Segundo Pintaudi (2005) as demandas da população estão muito próximas à solução de problemas da vida cotidiana dos cidadãos e da satisfação de suas necessidades. Não se estabelece um diálogo que vai no sentido da emancipação social e da construção coletiva da cidade. Tratam-se de projetos em curto prazo. É necessário que se obtenha uma superação das simples demandas da reprodução 
imediata da vida com a concepção de um projeto de futuro para que se consiga efetividade como instrumento de gestão. O que está no plano da reprodução da vida diária se encontra em um plano restrito, que prima pela solução individual e pontual dos problemas.

Ocorre que a reprodução imediata da vida é emergencial. Sem isso não é possível pensar no futuro. Num país como o Brasil, onde grande parte da população possui inúmeras carências básicas para a reprodução da vida, podemos pensar em criar um pensamento coletivo de futuro? É possível pensar isso conjuntamente com a população que, muitas vezes, não tem sequer alimentação e um lugar digno para viver? Como focar o pensamento sobre o debate sobre futuro das cidades também na população e não só nas elites intelectuais, políticas e econômicas? Como tornar esse debate público?

O processo do orçamento participativo, que possui um viés educativo, pode iniciar o debate sobre o futuro da cidade junto à população, no entanto, não se trata de um processo rápido. É necessário também que exista uma melhora na condição de vida da população e na educação que Ihe é direcionada. Porém é necessário que nos questionemos também sobre o interesse do poder político na emancipação da sociedade. Há interesse das instituições políticas em construir um projeto de futuro coletivo?

\section{Orçamento Municipal}

O orçamento público é um instrumento de gestão mais do que de planejamento, pois sua execução se dá no prazo de um ano e durante esse período ocorrem diversas ementas e remanejamentos de verba. Na escala local, ele é um instrumento de gestão urbana que contém uma importância social muito grande, visto que será o orçamento que definirá as políticas públicas da cidade e atenderá as carências mais pontuais e emergenciais da população. Porém, podemos afirmar que além de ser instrumento de gestão urbana é também um instrumento político, porque é através de sua manipulação que se fazem acordos e se estabelecem alianças políticas, que se privilegia o atendimento de certas prioridades em detrimento de outras. Ao analisarmos uma prefeitura que dispõe para discussão do $\mathrm{OP}$, a totalidade de seus investimentos, como é o caso da prefeitura de Porto Alegre/RS, conforme descrito por Souza $(2002,359)$, estamos tratando de um caso onde o orçamento municipal não é mais utilizado, teoricamente, como instrumento 
político, junto às alianças e negociações político-partidárias, pois ele está totalmente designado para discussão e deliberação da população. No entanto, durante todo o seu livro "Mudar a Cidade: uma introdução crítica ao planejamento e gestão", o autor não discute e não apresenta os resultados materiais alcançados com a implementação do OP na cidade de Porto Alegre/RS, embora ele assinale e, concordamos com sua afirmação, que não são exclusivamente os resultados materiais a principal conquista do OP. Devemos levar em consideração também os resultados "político-pedagógicos". No entanto, é fundamental que se apresentem os resultados materiais alcançados, ou seja, um balanço que demonstre durante os anos de realização do OP, quais foram as demandas e quais foram as obras e serviços realizados, para que possamos ter um quadro real do funcionamento desse processo e para sabermos se realmente $100 \%$ dos investimentos foram aplicados segundo as demandas da população. Também é necessário apresentar a maneira como foi dito a população quando da não realização de determinada obra ou serviço, esse é um fator muito importante, porque sabemos que orçamento não significa propriamente "dinheiro em caixa", então a arrecadação pode sofrer alterações e sempre é a parte de investimentos que sofre os primeiros cortes. Esse debate é de extrema importância para que todos tenham consciência do funcionamento real do orçamento municipal e saibam porque determinadas demandas não puderam ser atendidas.

Para retomarmos a questão do orçamento municipal sendo utilizado como instrumento para execução de acordos políticos, nos parece essencial discutir a relação do OP com o poder legislativo, ou seja, com a Câmara de Vereadores. A destinação de $100 \%$ dos investimentos para o OP pode causar uma crise com o poder legislativo municipal, pois eles perdem a margem de manobra que tinham para fazer seus acordos políticos, remanejando verbas, através de ementas, para obras e serviços que beneficiem os bairros e região eleitoral de seu domínio o que, muitas vezes, pode garantir sua reeleição. Embora, saibamos que a função de um vereador se restringe as questões legislativas e não executivas, essas práticas são comuns em inúmeras cidades e garantem coesão e base parlamentar para que o governo executivo possa executar projetos e programas. Não surge em nenhum momento da análise sobre o orçamento participativo de Porto Alegre/RS realizada por Souza (2002), como é trabalhada questão da destinação de todo investimento para decisão da população. 

em Rio Claro/SP.

Já no município de Rio Claro/SP, o OP trabalhava com a fatia de 1, 27\% do orçamento municipal, o que significava um valor em torno de $R \$ 2.000 .000,00$. Se analisarmos essa cifra, em relação, a fatia de investimentos, ela equivalia a $7,47 \%$ do total dos investimentos feitos pelo Município. Não representava uma porcentagem muito alta, porém o uso dessa verba de investimentos em Rio Claro/SP trouxe uma aproximação entre a população e a administração municipal e também uma maior compreensão por parte da administração e da população dos problemas que ambos enfrentavam. A interferência real nos investimentos é bastante reduzida e durante os sete anos de execução do processo ela não foi aumentada. Isso pode evidenciar que há um convite feito pela prefeitura para a discussão de uma pequena parte dos investimentos, mas que o objetivo maior, ao menos da prefeitura, é talvez a aproximação entre Estado e sociedade, mas não a partilha de poder. A grande parte do poder de decisão sobre os investimentos municipais continuou nas mãos do prefeito e seus assessores.

\section{Gráfico 1 - Gastos da Prefeitura de Rio Claro/2004}

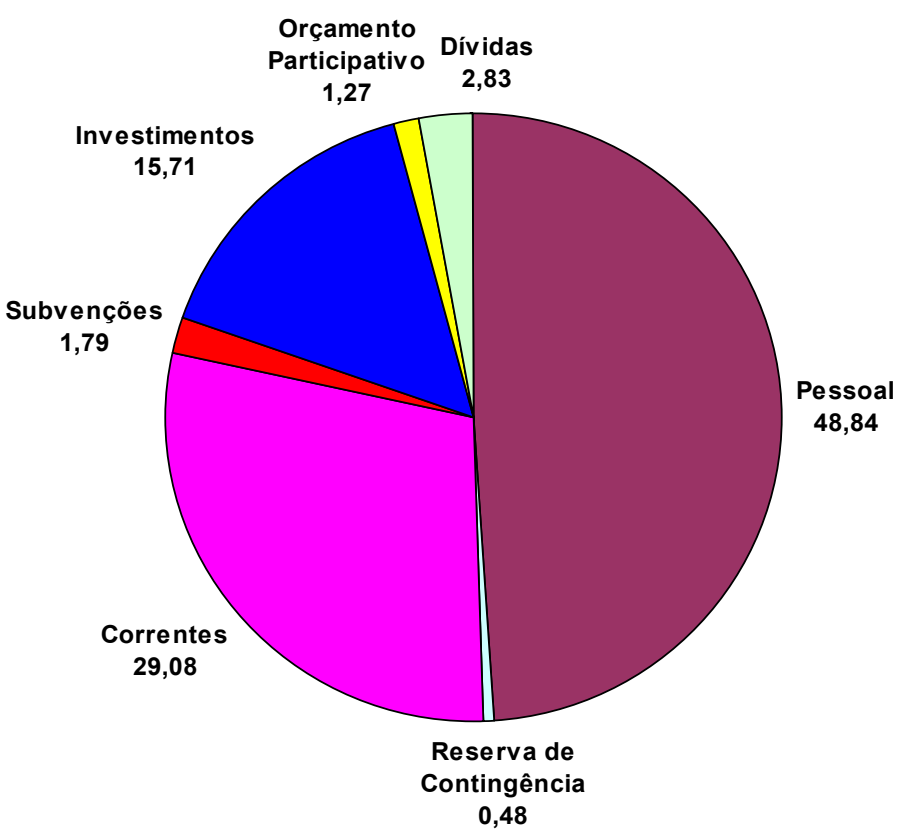

$\mathrm{Na}$ análise do gráfico acima verificamos que grande parte do orçamento municipal já estava comprometida com gastos que não podiam ser alterados. O pagamento de salários dos funcionários, aposentados e pensionistas municipais, utilizava quase $50 \%$ dos gastos da Prefeitura. A manutenção dos prédios, obras e 

em Rio Claro/SP.

serviços oferecidos pelo Município correspondiam a $29 \%$ do recolhimento financeiro da Instituição. O Município também tem uma dívida herdada de administrações passadas, que foi feita em dólares, o que também traz gastos bastante altos e instáveis, devido à variação cambial, para a Prefeitura.

Essas informações eram passadas para a população que participava das reuniões regionais, para que elas conhecessem os compromissos que a administração possuía. Para que a população pudesse compreender melhor o funcionamento do orçamento municipal utilizava-se a comparação com os gastos que as pessoas corriqueiramente têm em suas residências, gastos esses que não podiam ser modificados ou não cumpridos, como pagamento de aluguel, contas de energia, compra de alimentos, etc. Isso faz com que os cidadãos tenham uma maior aproximação e compreendam de maneira mais fácil as responsabilidades de uma prefeitura.

Uma outra questão que também era bastante discutida nas reuniões regionais com os participantes tratava-se da necessidade de manutenção e contratação de pessoal para o funcionamento das demandas da população. Muitas vezes ocorria que os cidadãos não compreendiam que para a construção de uma escola, por exemplo, não é necessária somente a construção do prédio, é necessário também que se contratem professores, merendeiras, diretores, auxiliares de serviços, etc. e também é fundamental a manutenção do prédio, como pagamento de energia elétrica, telefone, merenda e demais serviços necessários. Em tese é preciso calcular o preço de construção de uma escola e a verba de manutenção anual para cada escola construída. Essa explanação fazia com que os moradores dos bairros, aos poucos percebessem que não podiam ter uma escola, creche e/ou posto de saúde em cada bairro da cidade, o que ocorria no início do processo, como relatado por funcionários da prefeitura municipal de Rio Claro/SP. No entanto, não eram todas as pessoas que tinham essa apreensão, sendo fundamental o papel dos técnicos da Prefeitura de explicarem, muito claramente, para os moradores, quais eram as possibilidades de implantações de determinadas obras em determinadas localidades.

Um outro fator que deve ser levado em consideração, quando analisamos o $\mathrm{OP}$ em Rio Claro/SP, é que muitas vezes durante as negociações que eram feitas no COP, entre população e administração municipal, havia uma complementação de verbas quando o dinheiro destinado pelo OP, não era suficiente para a realização 

em Rio Claro/SP.

plena de uma obra considerada necessária. Como exemplo podemos utilizar a discussão em torno da construção da escola, no bairro Jardim Novo I (região 6), colocado anteriormente.

Precisamos apontar também que o investimento planejado diferia do investimento realizado/alcançado. Os investimentos planejados pela população junto ao OP, podiam não ser realizados por questões financeiras, porque se trabalhava com um orçamento e não com dinheiro "em caixa". No entanto, muitas vezes, questões ligadas às alianças políticas faziam com que as prioridades de investimento dos municípios fossem modificadas e que as reivindicações do OP não fossem prioritárias, como o discurso político diz que são. Como exemplo, podemos citar o Pacote de Obras lançado pelo município de Rio Claro em agosto de 2004, onde o investimento de $R \$ 4.000 .000,00$ contemplava apenas uma pequena parte das obras definidas pelo COP 2004. Por se tratar de um ano de eleições municipais as estratégias políticas se sobrepuseram ao que havia sido estabelecido pela população, nas diversas reuniões do OP, ficando esta à mercê do poder executivo, de suas decisões e de seu controle. Em anos anteriores este fato não ficou tão fortemente evidenciado, pois de maneira geral as reivindicações da população foram melhor atendidas, quando não atendidas, houve uma explicação aos conselheiros do porque não puderam ser realizadas as prioridades elencadas pelo OP.

\section{A Normatização dos Processos de Participação Popular}

O processo de reprodução espacial é conflitante porque contém estratégias de grupos sociais diferenciados. Como é planejado e organizado pelo Estado, o espaço revela sua estratégia, que teoricamente é objetivo e neutro, porém o espaço é utilizado como instrumento político de dominação e revela a estratégia de uma classe dominante, sob o discurso de representar toda a sociedade. Essas estratégias são claramente percebidas quando observamos a atuação dos vereadores de uma cidade, sempre defendendo os interesses do seu eleitorado que se situa em uma porção do território da cidade. A atuação dos vereadores é bem determinada por ações pontuais que visam trazer benefícios à população deste determinado local, garantindo com essa ação os seus votos e sua reeleição. Muitas vezes, não há uma defesa por interesses gerais da população, o interesse e as prioridades de atuação dos vereadores focam-se no seu eleitorado e estes trazem 
benefícios (asfaltamento, iluminação pública, etc.) para determinado local que tem um potencial eleitorado.

O Estado "tem a seu cargo a orientação e a definição de metas que planificam o espaço (tanto no plano geral da sociedade quanto no plano micro do bairro dentro da cidade)" de acordo com Carlos (2001, p. 29). Quando o Estado dá a possibilidade da população interferir na definição de metas, mesmo que seja uma interferência no plano micro-bairro, ele corre o risco de que suas estratégias sejam modificadas naquele espaço, porque a partir do momento que o Estado, tratando-se aqui de governo municipal, não define sozinho o planejamento de determinado lugar, ele será contido de estratégias diferentes que poderão não convergir com as estratégias políticas e da classe dominante.

Por isso mesmo, a maioria das cidades que executam o OP não trabalha com a definição total das verbas do orçamento municipal, o OP é define parte da verba de investimentos. A definição das verbas restantes permite o jogo de estratégias que irão culminar com a recorrente dominação do espaço pelo Estado. Fica aqui novamente nossa dúvida com a execução do OP em Porto Alegre, visto que nesta cidade, se discute através da participação popular $100 \%$ dos investimentos, porém não sabemos como fica o jogo de estratégias que está contido na ocupação do espaço.

O OP é gerenciado pelo Estado. São as prefeituras municipais que, através da vontade política de seus prefeitos eleitos, ou seja, do poder executivo, decidem implantar o processo de discussão popular de parte do orçamento municipal. Os processos do OP não têm um modelo, um padrão que deve ser seguido. Não há uma fórmula que deverá ser aplicada em todos os municípios. A questão é muito mais complexa do que isso.

Não podemos nos esquecer que sendo gerido e organizado pelo Estado, pelo poder político, o OP contém objetivo, lógica e racionalidade desse Estado, sendo todo o processo mediado e comandado por ele. A racionalidade do Estado, costumeiramente, está baseada em leis e assegurada por estas. O OP não foge a esta regra e em muitas cidades ele agora faz parte da Lei Orgânica Municipal. Esta presença na legislação municipal permite a permanência de mecanismos da política de democracia participativa, pois depois de implantada, mesmo uma administração conservadora dificilmente conseguiria criar um ambiente político favorável a eliminação do OP, pois com ele legalizado a força para reivindicar sua permanência 
é maior. Isso garante os benefícios da participação popular para uma futura gestão. Isto não aconteceu no município de Rio Claro e hoje o processo foi totalmente abandonado.

Referimo-nos aqui da institucionalização da democracia participativa, que traria à princípio uma maior normatização da participação popular, podendo resultar em um distanciamento da população em geral aos processos de participação popular e uma maior aproximação desses processos às regras e racionalidade estatal. Aqui enfrentamos um embate, porque a não institucionalização pode levar ao término e abandono das práticas de gestão democrática pelos governos avessos a esse tipo de participação. Porém a burocratização desses instrumentos pode trazer também o distanciamento e, muitas vezes, a indiferença da população, que é a mais beneficiada com essas práticas. No caso do OP em Rio Claro/SP, o que ocorreu com a troca de governo foi o abandono do processo. Durante seus 7 anos de execução a administração municipal optou por torná-lo algo acessível à todos, sem burocratizá-lo. Ao mesmo tempo, o processo não foi apropriado pela população porque sempre houve a tutela e o comando da administração pública, perpetuandose durante 7 anos devido a vontade política. Esses fatos trouxeram a extinção do processo. Mas, se tivesse ocorrido a normatização do OP em Rio Claro, se ele tivesse sido previsto em lei municipal, o que teria acontecido com o processo após a troca de governo? Muito provavelmente a lei teria sido revogada e o processo teria sido abandonado da mesma forma, pois o essencial não ocorreu, o processo não foi apropriado pela população, não se criaram as condições básicas para a permanência de um processo de participação popular.

No entanto, os processos de institucionalização já se apresentam e o Estado está cada vez mais interessado em tornar as ações de democracia participativa uma norma. Prova disso é a regulamentação dos artigos 182 e 183 da Constituição Federal, com a promulgação da lei federal $n^{\circ}$. 10.257, denominada Estatuto da Cidade, em 10 de julho de 2001.

Essa Lei, entre outras atribuições regulariza a participação da população nas decisões políticas do município, que se referem ao espaço urbano e ao seu desenvolvimento. Em diversos momentos do documento, a participação popular é uma prática defendida. No artigo $2^{\circ}$ do primeiro capítulo encontramos: 
A política urbana tem por objetivo ordenar o pleno desenvolvimento das funções sociais da cidade $\mathrm{e}$ da propriedade urbana, mediante as seguintes diretrizes gerais:

II - gestão democrática por meio da participação da população e de associações representativas dos vários segmentos da comunidade na formulação, execução e acompanhamento de planos, programas e projetos de desenvolvimento urbano;"(art. 2 , § II).

Em diversas outras partes do texto legislativo a gestão popular é assinalada. O Orçamento Participativo especificamente é citado no Capítulo II, Seção I, Parágrafo III, Ítem $f$, que dispõe sobre o planejamento municipal obrigatório e a necessidade da gestão orçamentária participativa, que deve integrar o plano plurianual, o orçamento anual, a lei de diretrizes orçamentárias para que sejam aprovadas pela Câmara Municipal.

Acontece que o Estatuto apenas cita a necessidade de integrar a participação da população nas diversas práticas de gestão das cidades, como o orçamento municipal, porém a implantação desses instrumentos fica a cargo das prefeituras municipais e são estas que deverão regular a prática participativa. Na lei federal não fica definida uma metodologia. O desafio é lançado e caberá a equipe das prefeituras implantá-lo com os critérios que os convier. Fica então o questionamento sobre como e em que bases e pressupostos esses processos serão implantados.

Em todo o seu texto, o Estatuto da Cidade fortalece a lógica que favorece a estratégia hegemônica onde, o valor de troca sobrepõe-se ao valor de uso, o que faz com que a cidade se torne não só o lugar do consumo, mas também um objeto de consumo. Dessa forma, é favorecida a produção da ilegalidade, já que, as pessoas são expulsas do centro e da cidade legal, que contém toda infra-estrutura e estão dentro da normatização institucionalizada, como: código de obras, plano diretor, etc.

Segundo Barbosa \& Limonad (2003) o Estatuto da Cidade contribui, antes de mais nada, para regulamentar e normatizar a mercantilização da cidade com a possibilidade de o poder público - no caso as prefeituras - apropriar-se de parte das rendas que gera através de sua intervenção e disciplinarização da (re) produção do espaço urbano materializado na cidade.

Como exemplo de intervenções problemáticas contidas no Estatuto podemos citar: os critérios de zoneamento que são responsáveis pela segregação residencial, preservando espaços para o uso das elites; os padrões elitistas dos códigos de obras municipais e leis de loteamentos que contribuem para a expansão da cidade 
ilegal e a correlação entre o coeficiente de aproveitamento, taxa de ocupação e gabarito, que pode levar a expulsão de pequenos proprietários não-capitalistas.

Isto faz com que se fortaleça a expulsão das pessoas com menores rendimentos das áreas mais privilegiadas e centrais da cidade, fazendo com que elas migrem para a periferia e busquem estratégias de sobrevivência que as colocam fora do "mundo legal e formal", onde a desigual distribuição dos recursos públicos é bastante evidente. O modo de produção capitalista que captura o espaço da cidade como um importante elemento do consumo é responsável pela ilegalidade e informalidade. As ações político-institucionais que operam a favor de uma classe economicamente hegemônica são os responsáveis pela desordem urbana, com a qual o Estatuto da Cidade quer acabar. Ocorre que as decisões sobre o Estatuto, principalmente as ligadas à questão da participação popular, ficam subordinadas aos interesses dos governos locais e ao compromisso político desses governos com sua população. Assim, como aconteceu com a municipalização do ensino público fundamental, o Estatuto deixa a mercê de decisões pontuais e locais as orientações de políticas públicas importantes para toda a população. Ele permite, por exemplo, que a participação popular seja utilizada apenas como um mecanismo legitimador de sua intervenção no espaço, pois possibilita sua utiliza para legitimação de ações táticas. Isto porque não regulamenta a participação popular e sua forma de implantação, deixa essa responsabilidade para os governos municipais, que então podem implantá-la da maneira que melhor convir para seus objetivos.

A normatização imposta pelo Estatuto da Cidade oculta algo que é inerente ao sistema capitalista e que se evidencia no espaço e nas reivindicações do OP. Oculta as tensões, os conflitos e as contradições que estão presentes na sociedade urbana e que se revelam no espaço urbano, que é construído socialmente e apropriado privativamente. Não contempla que, "em uma sociedade onde impera a desigualdade, aquilo que é bom para uns não necessariamente o é para outros" como coloca Barbosa \& Limonad (2003). As normatizações apresentadas por esta lei federal fazem com que as diferenças sejam apagadas e ocultadas em nome de uma padronização do espaço urbano e de sua regulamentação comum. Ocultando as diferenças se restringe a possibilidade de apropriação deste espaço e da realização do uso. A mercantilização do espaço da cidade se sobrepõe a sua apropriação coletiva. 
Porém, a obrigatoriedade da discussão do orçamento municipal nas cidades brasileiras traz um aspecto positivo que é o de propiciar a aproximação da população às questões administrativas e orçamentárias dos municípios. Isso acontece também com a discussão do plano diretor que prevê a participação dos cidadãos em sua elaboração, fiscalização e implementação. Há um maior controle das ações da administração municipal. Todas essas normas são bastante positivas e trazem um maior contato entre a sociedade civil e a administração municipal, contato esse que até então era permeado pelo clientelismo e troca de favores. $\mathrm{Na}$ verdade, toda a população pode passar a fazer parte da administração municipal, desde que ela tenha um "espaço aberto" pelo poder executivo, onde possa opinar, interferir e conhecer mais de perto o que anteriormente apenas conhecia através de algumas informações que eram veiculadas na mídia local e por contatos diretos no bairro, no local de trabalho.

Há também os aspectos negativos dessa institucionalização, um deles já apontado; é a questão do distanciamento da população devido à burocratização e normatização desses processos. A população não está acostumada e têm certa aversão às questões políticas pois as relacionam à corrupção, às irregularidades e inutilidades. Acreditam que estes temas estão muito distantes dos seus problemas cotidianos e não fazem parte de sua vida, em suma, seus problemas individuais são os que devem ser resolvidos. A atividade política está desacreditada por essa população e está também desacreditada como possibilidade de transformação da sua realidade. Dessa maneira, a institucionalização pode talvez apenas aprofundar essa imagem e esse distanciamento. $O$ uso da participação popular para legitimação de ações sem probidade, por parte de governantes que não tem compromisso com a gestão honesta e justa, também é outro aspecto negativo que pode transformar a discussão popular do orçamento em instrumento de legitimação de ações duvidosas.

Um outro problema ligado à normatização do OP e dos demais processos de participação popular é o uso improcedente dessas práticas, por parte de políticos de má fé, pois agora que se tornaram obrigatórios, estes instrumentos podem ser utilizados de maneira errônea e trazer uma manipulação da opinião das pessoas que participam. O uso incorreto desses instrumentos traria uma inversão do objetivo inicial dos processos de participação popular, que é a efetivação da democracia, pois a manipulação da vontade de participar traz de volta o problema da onipresença do poder político partidário e de sua "ideologia" na gestão municipal. Seria um 

em Rio Claro/SP.

"drible" na legalidade: a lei é cumprida, os processos são realizados e o marketing do OP é um instrumento que legitima seu governo ao mesmo tempo em que seus ideais políticos são assegurados. Dessa maneira, a democracia, aqui entendida como um regime de soberania popular onde devem ser respeitados os direitos humanos de todos os indivíduos. Entretanto, todos os direitos econômicos, sociais e culturais não são respeitados. A soberania popular é ultrajada e manipulada.

Um compromisso autêntico com a participação é indissociável de um respeito à autonomia da sociedade civil. A tentação de exercer uma influência paternalística sobre o processo precisa ser evitada. Uma tal influência, não necessariamente impositiva mas, de todo modo, manipuladora, ocorre, por exemplo, quando técnicos progressistas apresentam óbices ou obstáculos 'técnicos' para certas demandas da sociedade civil sem esclarecê-los devidamente, o que bem pode servir para viabilizar a aceitação da posição do próprio governo a respeito de dado assunto. (SOUZA, 2002 p. 399).

Essa afirmação nos coloca algumas questões. Primeiramente, um fato que nos chamou a atenção foi o da possibilidade de manipulação da população por parte dos organizadores do processo, caso não haja um devido esclarecimento frente aos obstáculos técnicos de determinada prioridade. Perguntamos-nos: qual seria esse devido esclarecimento? Sabemos que o processo de participação popular demanda principalmente tempo. Exige o compromisso de quem organiza para que a população possa se apropriar dele. Como já colocamos, o problema da apatia política que encontramos hoje na população dificulta muito os processos de participação popular. Essa é uma primeira barreira a vencer. Posteriormente, há a questão do esclarecimento técnico, que grande parte da população não possui, para se compreender as questões administrativas, financeiras e técnicas de uma prefeitura, isso traz uma série de problemas para o início de implementação de um processo de participação popular. Para ilustrar essa questão, um exemplo bastante representativo foi vivenciado no início da implementação do OP em Rio Claro/SP. As primeiras reuniões revelaram um curioso fato, a maioria dos bairros da cidade, demandavam uma creche, uma escola e um posto de saúde ou hospital no seu bairro. A necessidade de grandes deslocamentos para uma população que utiliza transportes coletivos, muitas vezes longos, e a falta de atendimento eficaz, em escolas, creches e postos de saúde para atender à todos, fez com que a população decidisse que a implantação desses equipamentos em cada um dos bairros da cidade se apresentasse como a solução ótima para a resolução de seus problemas. 

em Rio Claro/SP.

Para os técnicos da prefeitura isso se apresentava como uma solução absurda, pois eles conheciam a inviabilidade financeira dessa solução, mas a população não tinha esse esclarecimento. Ela tinha seu problema e procurava a melhor solução para resolvê-lo, no entanto, essa solução era totalmente inviável financeiramente, visto que, o município tem um limite de recursos do orçamento para pagamento de funcionários e investimentos. A partir desse fato houve um intenso trabalho de explicação e esclarecimentos por parte dos técnicos da prefeitura para mostrar e fazer com que a população entendesse o porquê é impossível construir escolas, creches, postos de saúde em todos os bairros da cidade. Esse trabalho não evitou que durante anos houvesse bairros que pedissem a construção de postos de saúde, por exemplo, onde no bairro vizinho já existia um posto de saúde. Isso indica que nem sempre a resposta técnica é devidamente esclarecedora para a população. Ela continua a acreditar que deveria se implantar postos de saúde em todos os bairros. Mas aqui aparece uma outra questão: como e quem decide onde serão implantados as novas creches, escolas e postos de saúde na cidade? Na verdade são os técnicos, já que são eles que têm a informação de quantas pessoas são atendidas por cada posto de saúde, onde há maior demanda e em qual bairro a população tem que se deslocar mais para ser atendido, qual é o bairro ou região mais carente. Embora a população viva isso cotidianamente, ela não tem a visão geral das necessidades de todos que vivem na cidade. Os técnicos encaminham ao COP o mapa de demandas da cidade para que eles determinem o local de implantação da obra. Há uma orientação para a população.

Existe uma questão dialética sobre a influência manipuladora, pois uma obra pode se apresentar como estritamente necessária à cidade, como pode também viabilizar a posição do governo ou um programa de governo. Essa é uma questão bastante delicada onde há um fio muito estreito entre honestidade técnica e manipulação da opinião e decisão popular. Pode haver uma legitimação das ações previamente definidas pelo Estado através da participação popular. Esse fato comprova que a autonomia da população, se ela existe, é bastante relativa. Uma outra questão que se apresenta quando analisamos a afirmação de Souza (2002), anteriormente citado, é relativa ao mandato político do prefeito. Até que ponto o prefeito, seu partido político e as alianças políticas estabelecidas estão dispostos a arriscar o mandato ou a vida política, dando tal autonomia à população como propõe o autor? A carreira política de um prefeito e de seu partido é marcada 

em Rio Claro/SP.

essencialmente pelas realizações e benefícios alcançados durante um mandato, sem dúvida nenhuma a implementação da participação popular na vida política de uma cidade é algo bastante louvável para um prefeito, no entanto, é suficiente para sua manutenção no poder? Não é necessário que existam também obras realizadas de grande e médio porte para que seja marcado o seu mandato? Não que concordemos com a realização de obras faraônicas, porém sabemos que a prática corrente é a realização de obras marcantes para que políticos sejam reeleitos ou elejam seus sucessores. Isso não traz nenhuma influência para a manipulação da população na hora de decidir por uma ou outra obra? Fica difícil respondermos a essas perguntas, pois cada experiência se desenvolve de maneira particular e a manipulação da população, embora não desejada e, muitas vezes, não pensada, pode acontecer de maneira bastante sutil e mascarada.

Prova de que, mesmo no OP de Porto Alegre/RS, existem diferentes interesses entre Estado e sociedade e de que a autonomia é bastante restrita ou praticamente não existe pode ser extraída do próprio texto do autor, quando ele nos relata que um conselheiro do OP de Porto Alegre/RS disse já ter pensado na importância da existência de uma equipe técnica autônoma independente da prefeitura e de que o conselheiro considera que essa equipe poderia provir até mesmo da prefeitura, desde que indicados pelo Conselho do Orçamento Participativo. Nesse momento o autor faz o seguinte comentário, entre parênteses, sobre a sugestão do conselheiro:

... coisa que não parece muito recomendável, haja vista a possibilidade de restrições à liberdade de crítica e até mesmo por causa de conflitos íntimos derivados da situação de dupla lealdade.(Souza, 2002 p. 461-462).

Este trecho nos mostra que há conflitos de interesses, e, muitas vezes, os técnicos das prefeituras estão entre estes conflitos e nitidamente haverá uma posição que pende ao interesse da administração municipal, pois é ele seu empregador e é ele também quem determina quais funcionários acompanham o processo do OP. Isso comprova que há uma presença bastante forte do Estado durante a realização do processo e mesmo que essa presença não possa votar durante as deliberações de prioridades e uso do orçamento dos investimentos, é ela quem dá todas as informações técnicas e as diretrizes das obras.

Parece-nos que a ordem distante, o poder das grandes instituições, é esquecida pelo autor, ele a ignora dando a entender, diversas vezes, que a 

em Rio Claro/SP.

população tem autonomia e age sozinha, esquece da imposição de poderes superiores que transborda ideologias dominantes e as impõe na cidade, seja ela qual for. Isto faz com que interesses alheios à população estejam presentes no debate do orçamento municipal e não permita a autonomia da população frente a um processo que é comandado e proposto pela administração municipal. 


\section{Capítulo 3 - Gestão Participativa e Cidadania}

O processo do Orçamento Participativo, mesmo com seus aspectos negativos e contradições, é um avanço e um ganho para o crescimento da participação cidadã e para o desenvolvimento e aperfeiçoamento da democracia em nosso país, porque ele possibilita um espaço de debate e a efetiva participação de pessoas, que até então, se encontravam à parte do processo de discussão sobre o orçamento municipal. Sem dúvida, ele se configura como um modo de manifestação e uma oposição ao período da ditadura militar, vivida na década de 1970 e 1980 no Brasil. No entanto, temos que ser bastante cuidadosos quando trabalhamos com esse processo e colocamos nele uma dose exagerada de otimismo e militantismo, transpondo para o processo a idéia de um instrumento emancipatório e libertador. Temos que nos lembrar que essa ainda é uma participação comandada pelo Estado. É o Estado quem produz, induz e organiza a participação que presenciamos hoje e que tem como caráter principal a reivindicação. Por se tratar de um processo induzido e comandado pelo Estado, o OP vai revelar estratégias e ações que fogem ao alcance do entendimento e da ação da população, as estratégias políticas, as alianças entre partidos aparecem durante o processo e determinam ações que não contém e não contemplam a discussão popular, pois o jogo de forças entre os poderes políticos estabelecidos institucionalmente, muitas vezes, sobrepõem-se à vontade popular.

O OP também surge frente ao contexto político que nos é apresentado por Carlos (1996, p.40): O Estado-Nação tornou-se impotente no sentido de poder definir independentemente uma política industrial, monetária ou cambial, além do que se mostra incapaz de assegurar benefícios como no passado (como por exemplo, as políticas de bem-estar social).

Esse novo comportamento do Estado é revelado nas demandas do OP. Os benefícios, principalmente os ligados ao bem-estar social, pois são esses que estão diretamente ligados às demandas das reuniões do OP, não são mais fornecidos pelo Estado, que dentro da lógica capitalista neoliberal se isenta dessas responsabilidades sociais preocupando-se com as questões econômicas, isso faz com que os municípios se depararem com novos problemas e responsabilidades e a população se remete ao poder local para solucionar seus problemas que são emergenciais e imediatos. Quando analisamos as demandas do OP de Rio 
Claro/SP, o que temos é o reflexo da afirmação acima, pois o Estado-Nação se isenta das responsabilidades sociais e os municípios as agregam.

Há aqui uma contradição pois, embora as responsabilidades dos municípios cresçam, sua autonomia também cresce frente a alguns setores, embora esses estejam sempre contidos da lógica superior global que hoje alcança todos os lugares.

Segundo Carlos, (1996 p. 42) o Estado produz o espaço regulador e ordenador que reproduz a oposição centro-periferia e onde há centros dominadores que exercem uma dominação sobre um espaço dominado e que, dessa maneira, controlam a organização, a administração, a jurisdição, a fiscalização e o político dessas periferias, ou seja, espaços dominados e conseguindo assim, coordenar e submeter às estratégias globais do Estado, reproduzindo um espaço de confrontos e conflitos.

... a democracia funciona apenas no plano institucional, na organização e derrubada de governos pelo voto. Na prática, quem manda são organismos como a Organização Mundial do Comércio e o FMI, que não são eleitos democraticamente, são instituições imperiais. Na falsa democracia mundial, o cidadão está à deriva, sem oportunidade de intervir politicamente e mudar o mundo. Atualmente somos seres impotentes diante de instituições democráticas das quais não conseguimos nem chegar perto. (SARAMAGO, 2005).

Frente a essa afirmação e aos processos de corrupção que vivenciamos atualmente, encontramos um quadro entre nossa população de uma generalizada apatia política e de participação, vista muitas vezes, como um fardo. O comodismo faz com que as pessoas, mesmo desconfiadas e cada vez mais desacreditadas dos "políticos profissionais" e seus partidos, entreguem todo seu poder de decisão a eles. Esse comportamento de comodismo e apatia é estritamente funcional para o sistema de dominação implantado na sociedade capitalista. Adiante trataremos com maior detalhe essa questão.

O grau de otimismo e valorização que se dá a processos como o OP, pode nos levar a interpretações equivocadas sobre o alcance deste instrumento. Souza (2002, p. 335) afirma que:

...assume o autor [Souza] com convicção, que a participação não é um simples acessório, nem mesmo apenas uma ferramenta útil. Participar, no sentido essencial de exercer a autonomia, é a alma mesma de um planejamento e de uma gestão que queiram se credenciar para reivindicar seriamente o adjetivo democrático. 
Discordamos de Souza, pois acreditamos que o OP é uma ferramenta, enquanto ele não for totalmente apropriado pela população e continuar a ser proposto e coordenado pelas administrações municipais, prova disto é o ocorrido no município de Rio Claro/SP. Perguntamo-nos onde está a autonomia se o processo é comandado pelo Estado, que até pode ser progressista, mas que tem seus interesses acima de tudo e que age sobre uma lógica superior que é a do capital. Mais do que afirmar que a participação contribui para o exercício da cidadania, o que também pode apresentar dúvidas, o autor afirma que participar é o exercício da autonomia.

O OP apresenta uma participação reivindicatória e não autônoma e emancipatória. Caso o Estado, no caso estudado, a administração municipal de Rio Claro, não apresentar uma resposta positiva às reivindicações colocadas, ou seja, não realizar as obras e serviços solicitados há um esvaziamento da participação. Esta população participa para ver suas reivindicações pontuais serem atendidas de maneira mais imediata e não porque se sentem parte do processo, ou porque sabem que a verba da prefeitura é pública e, portanto, pertence a população e, por isso, ela tem co-responsabilidade nos gastos municipais. Não há um sentimento de pertencimento da "coisa" pública. O OP não acontece porque partiu da reivindicação da população, de uma cobrança por seus direitos, ele ocorre porque sana necessidades emergenciais da população e por ser um dos únicos caminhos a se percorrer para conseguir a execução de prioridades, para aqueles que não possuem relações diretas com o poder público e não dominam o setor econômico.

O poder final de decisão sobre os encaminhamentos do orçamento ainda está nas mãos do Estado, porque é o Poder Executivo quem decide se encaminha ou não o fruto das discussões do COP para a votação. É o poder Legislativo, mais pontualmente, a Câmara de Vereadores, quem aprova ou não o orçamento discutido e definido pelos membros da sociedade civil e será novamente o poder Executivo quem irá aplicar o orçamento aprovado, ou seja, o poder dos cidadãos é muito pequeno e pouco definidor de políticas ou ações mais efetivas e concretas. Este poder popular, quando não organizado e não conhecedor minimamente de estratégias políticas, fica limitado à indicação de prioridades e a espera de sua execução.

A relação que se instala nesse instante é dialética, porque os vereadores costumeiramente aprovam, sem alterações, a fatia orçamentária elaborada pela 
população. E o prefeito, de maneira geral, realiza as prioridades elencadas, pois afinal é esta população que os elege e permite que eles ocupem cargos na administração municipal. A pressão exercida, deste modo, é a ligada às urnas, aos resultados eleitorais. Não há um movimento social formado espontaneamente, vindo de baixo para cima que assegure a execução do que foi reivindicado.

Uma questão que nos parece importante ser colocada é que, sendo o OP um processo de participação popular, que conta com população como seu elemento base, o OP pode ser considerado como um movimento social? Parece-nos um pouco difícil responder afirmativamente esta questão, visto que, desde sua formulação até sua organização e implementação o processo do orçamento participativo é gerido e comandado pelo Estado, no caso, pelo poder público municipal. O processo tem sua origem e funcionamento realizado de maneira vertical, ou seja, de cima para baixo. Não há, ao menos no caso estudado do município de Rio Claro, uma reivindicação e uma movimentação da população clamando pela implantação desse modo de discussão de parte do dinheiro público. É algo proposto pelo Estado e por ele pensado.

Costa (1997) define: "Os movimentos sociais apresentam perfis organizativos próprios, uma inserção específica na tessitura social e articulações particulares com o arcabouço político-institucional."

Somente a afirmação de que movimentos sociais possuem "perfis organizativos próprios" já nos coloca a impossibilidade de dizer que o orçamento participativo é um movimento social, pois a organização própria da população não aparece nos momentos do OP, é justamente pela ausência dela, ou por sua pequena expressão, que algumas prefeituras municipais convidam a população para discutir questões referentes ao bem público, juntamente com o governo e, desta forma, aproximar representantes de representados. É a ausência de movimentos sociais, a ausência da reivindicação organizada do que está posto e do que está sendo produzido unicamente pelo poder público institucionalizado, que dá margem ao início da construção democrática da cidade proposta pelo Estado.

Se as possibilidades dos movimentos sociais estão no seu enraizamento junto as esferas sociais e que é na articulação dessas esferas com as instituições, que podem emergir impulsos promissores para a construção da democracia, segundo Costa (1997), o que o OP apresenta é a possibilidade de fazer surgir, de emergir movimentos sociais que até então estavam adormecidos, devido a falta de 
oportunidades e de iniciativas da população de se relacionar e se colocar perante os problemas que enfrenta. O OP pode proporcionar a emergência de movimentos sociais que se enraízem nas esferas sociais e estabeleça articulações com as esferas institucionais que fortaleçam a construção da democracia, mas por si só, ele não é movimento. Porém, para que esses movimentos sejam legítimos, eles têm que emergir naturalmente e partindo de um movimento da população, não é possível que eles sejam criados através da indução das administrações institucionais. Há que existir uma construção natural e que parta da própria população.

O processo do OP se dá de maneira dialética e contraditória porque ao mesmo tempo em que ele possibilita a aproximação da população e de líderes de possíveis movimentos sociais, o que traz uma maior legitimidade ao processo e uma disputa de forças mais dura, pois se cria um grupo, que conhece seus direitos e as possibilidades de atuação; o OP é um processo que está carregado da lógica do Estado e que, por isso, muitas vezes, opera numa lógica contrária a do desejo da população, posto que opera na lógica político-partidária, que visa, antes de tudo, se manter ou chegar ao poder. E então, tudo que está em oposição a isto incomoda, atrapalha, e os anseios e vontades da população podem atrapalhar. O OP faz parte de um projeto administrativo de um grupo institucionalizado e político, dessa maneira, o que principalmente interessa ao grupo é aquilo que traz um efetivo apoio a seu projeto e grupo governante.

A indução da participação popular foi a alternativa encontrada por parte das administrações municipais para que existisse uma aproximação entre a sociedade civil e o governo. A busca por essa aproximação pode ser reflexo do não contentamento frente a apatia e o desinteresse político da população com aquilo que é público, e processos como o OP conseguem estabelecer essa aproximação e fazer com que exista um diálogo entre esses diferentes elementos. Porém, os interesses são contraditórios e para que a representação da população possa se colocar e se posicionar abertamente é necessário que exista um distanciamento e uma autonomia da população frente às colocações do poder público. Em nosso entendimento, a partir do momento que, nas reuniões regionais do OP a população presente elege seus representantes populares e que, depois, elegerão os conselheiros do OP, e que a aproximação desses conselheiros com a administração municipal se estreita há uma perda da autonomia e esses conselheiros passam a ser mais diretamente influenciados pelo governo. Aqui nos é apresentado que um 
projeto de democratização proposto pelo Estado tem limites que o impedem de se tornar um processo emancipatório e revolucionário e que traga mudanças importantes na base institucional.

Costa (1997), na análise dos estudos de caso das cidades mineiras de Uberlândia, Juiz de Fora e Governador Valadares, que nos anos de 1980 implantaram experiências administrativas de cunho participativo, com destaque para a criação de Associações de Moradores, tornando-se os principais interlocutores da população com as administrações municipais, pondera que:

Politicamente ela [a circunscrição da democratização da esfera pública ao seu âmbito institucional] pode representar a indução ao surgimento de atores que, apesar de serem formalmente delegados da sociedade civil, apresentam-se desvinculados dos anseios e expectativas políticas da população. Reproduzirão assim, nas arenas institucionais, sua lógica sistêmica, divulgando demandas constituídas no âmbito estrito da própria organização ${ }^{3}$.

A construção da democracia não pode estar diretamente ligada ao poder administrativo institucionalizado. Uma sociedade civil ativa e participativa não pode ser educada em um curto período de tempo. ,É necessário que exista processos de participação comunitária que envolva os diferentes setores da sociedade civil e que os envolva na vida da sociedade em todos seus âmbitos. No entanto, hoje são os processos de participação ligados ao poder público que conseguem uma maior mobilização social e que aproximam a população da administração pública e, por isso, não podem ser ignorados e não se pode deixar de dar o importante papel que eles representam para nossa sociedade hoje. Mas não se pode desejar que estes processos se tornem os principais momentos de manifestações populares. É necessária a existência de reais processos de participação popular que tenham sua origem no seio da organização e mobilização popular e que, assim, alcancem um maior grau de autonomia e independência.

Não podemos deixar de nos reportar a afirmação de Pintaudi (2005, p.07), que nos alerta:

Quando a participação cidadã é um efetivo instrumento de emancipação da sociedade, ao mesmo tempo, deixa de ser funcional ao estado. Tomando isso em conta e todo o potencial que existe nesse instrumento de gestão pública, devemos compreender melhor seus limites e capacidades para não perder suas possibilidades de contribuir para a construção de espaços urbanos mais generosos para a reprodução da vida humana. Costa $(1997$, p.14) 
A racionalidade do Estado permeia todo o processo de participação popular, que acontece durante a realização do orçamento participativo e por isso, é ela quem domina. Por isso a emancipação da sociedade não está presente nos processos de participação propostos pelo Estado, pois eles não são funcionais à ele.

O funcionamento do processo está fortemente dependente da vontade política do prefeito e de sua organização e trabalho junto aos funcionários da prefeitura, que irão dar funcionalidade ao processo. E aqui se evidencia um outro problema a ser enfrentado por aqueles que se propõe a participar, na maioria das vezes o funcionalismo público, e até mesmo os políticos eleitos, estão despreparados para executar esse tipo de ação. Os funcionários envolvidos com a organização do OP têm acesso restrito às informações sobre o orçamento municipal. $A$ informação, tida aqui como uma forma de poder e dominação, impede um trabalho mais aprofundado e claro dos funcionários com a população, isto porque parte do funcionalismo público não vê em experiências como o OP possibilidades de transformação do que está posto e avanços para a democracia, mas vê essa nova forma de gestão como trabalho à mais para ser realizado. A prática do OP é algo novo, que foge ao cotidiano dos funcionários. Há também os funcionários e, incluimos aqui funcionários que possuem cargos políticos, que vêem o OP como algo perigoso, pois trará à população informações sobre questões que até então eram omitidas. A participação popular aparece então como algo indesejado, pois poderá quebrar com a lógica burocrática que é benéfica para muitos. Por isso, muitas vezes, as informações não são bem explicadas e divulgadas. Não estamos falando aqui somente de informações sobre situação das finanças, mas também sobre o funcionamento do orçamento municipal, que traz em si, questões bastante burocráticas e técnicas. Um dos desafios dos municípios é poder capacitar seu pessoal para que ele possa enfrentar as exigências e os desafios apresentados pela implementação do OP, e enfrentar os "feudos" que se criaram dentro das prefeituras e que se utilizam de informações, e da omissão delas, para benefícios próprios.

Esta relação entre Estado e sociedade propiciada pelo OP e os diversos outros conselhos temáticos se concretiza na vida urbana e se materializa na cidade. Este contato mais direto entre o poder instituído e o instituinte revela a crise pela qual a cidade vive e lança a responsabilidade de gestão compartilhada, o compartilhamento do que aparece na cidade, ou seja, da carência. Mistura-se o plano do vivido, que é como a cidade aparece e é vivida pela população e de outro 
lado o plano da gestão, como a gestão pensa sua atuação sobre a cidade. $O$ desafio situa-se na compreensão e no vislumbramento do processo de produção do espaço da cidade, que acontece através do OP. Trata-se de um instrumento de realização real e concreta da relação entre poder público e sociedade, no espaço.

O benefício relacionado à questão da educação política e da mudança de cultura, em relação a política, é um dos grandes avanços que este processo nos traz. Com o $\mathrm{OP}$ e também com as diversas outras práticas democráticas implementadas nas administrações municipais (Conselhos Municipais Temáticos, Conferência da Cidade, entre outros), a prática democrática ultrapassa o dia das eleições para transformar-se no que podemos chamar de prática democrática cotidiana. Pois parte da população passa a ter um contato mais direto com a administração municipal e conhece as possibilidades e limitações desta instituição. O quadro atual da democracia representativa, em nosso país, confirma sua ineficiência, pois os eleitores não se sentem representados por seus representantes políticos e se distanciam de tudo aquilo que se relaciona a política. O quadro mostra que alguns cidadãos não mais estão satisfeitos com a situação de distanciamento posta e por isso, buscam atuar no seu lugar, para que a reprodução e realização da vida aconteçam com mais qualidade e dignidade. Mesmo que essa participação, em princípio, seja apenas reivindicatória e comandada pelo Estado, sem ter surgido através da organização popular e de movimentos sociais, ela traz uma maior aproximação da população ao funcionamento do Estado. A população conhece os limites e as possibilidades de atuação desta instituição e tem, ao menos, a idéia de onde reivindicar; aproxima-se das instituições públicas com mais conhecimento. Há também um desenvolvimento, que não é imediato, da cultura política e da prática cidadã. É observado no decorrer dos anos de realização do OP em Rio Claro/SP, que muitos cidadãos têm uma nova visão e uma nova consciência do papel que eles podem exercer na sociedade.

Mas, para que o processo do orçamento participativo se consolide e seja incorporado pela sociedade é preciso que a população se aproprie do processo, que ela se torne o principal elemento da ação. Por isso, a irreversibilidade do OP está lado a lado com o empoderamento da população e a compreensão da importância do processo e dos benefícios que ele traz. Para chegar a isso, fica clara a necessidade de conscientização e educação dos cidadãos. 
Os processos de participação popular, de maneira geral, têm que se desenvolver para que possam alcançar um maior poder de decisão, de realização, de mudanças na gestão e organização das cidades e de transformações na sociedade. Estes processos ainda ocorrem de maneira muito isolada entre eles. Não existe uma conexão, um contato mais forte e estreito entre os diversos conselhos municipais, entre a Conferência da Cidade e o planejamento explicitado no Plano Diretor e no Plano Plurianual da administração municipal. Trata-se aqui da cidade de Rio Claro/SP em especial, porque é nossa área destacada. Esse contato, esse maior entrosamento poderá trazer mais força e até maior autonomia para a participação popular e para o poder de decisão e transformação dos cidadãos, já que hoje eles se apresentam como uma colcha de retalhos que não tem muito sentido e ligação para a população.

O OP não traz em si uma revolução que dá autonomia para a sociedade e emancipação para os cidadãos, o processo é uma evolução em relação ao que estava posto mediante as relações entre Estado e sociedade civil, que eram totalmente distantes. Podemos identificar no OP uma lógica de melhoramento da gestão, com a participação da população nas decisões orçamentárias do município; traz uma lógica social de inversão de prioridades e de construção de novas relações entre sociedade civil e governo.

\section{Cidadania}

A questão da cidadania é sempre apontada quando tratamos da questão do OP. Em todas as reuniões, em todas as ações realizadas e conquistadas esse tema é colocado e a cidadania é afirmada como um benefício conquistado. Talvez, realmente, o processo do OP enseje avanços e evolua em relação à realização da cidadania em nosso país, exaltada e afirmada inúmeras vezes através da mídia e de nossos políticos de maneira geral.

Martins (1999) discute o tema da cidadania como fruto de uma produção através de conflitos radicais que afetam a sociedade em sua base, proporcionando conflitos muito mais profundos e significativos, que os conflitos de classes e, não como produção da cansativa repetição de palavras que designa a cidadania. Para Martins (1999 p. 12) "A cidadania não é o milagre do discurso fácil."

O que acontece em nosso país, muitas vezes, é que o discurso da cidadania é mais forte do que sua efetivação. $E$ os diversos processos de orçamentos 
participativos, em várias cidades de nosso país, podem fortalecer esse discurso. Não podemos negar o avanço que a relação entre sociedade e Estado tem com a implantação dos OP's, porém dizermos que ele realiza e concretiza a cidadania entre a população é um tanto quanto equivocado e populista. A apreensão da população com relação ao questionamento do poder do Estado, da sua participação e influencia na gestão da cidade, ao direito à cidade e ao seu papel como sociedade civil é quase inexistente e muito longe de ser alcançado.

Parece-nos necessário iniciar a discussão sobre este conceito que, assim como nos processos do OP, foi incorporado por diversos discursos políticos e, principalmente pela mídia, e é usado hoje de maneira banal o devido questionamento de seu significado original e essencial. O conceito de cidadania, que segundo Saes (2003, p. 09) se transformou em um mito, assim como a palavra globalização, está presente e difundido amplamente na opinião pública sem que exista um mínimo de crítica sobre seu significado.

Saes (2003) nos leva a um percurso pela origem do conceito de cidadania, que tem sua definição ligada ao ensaio clássico de T.H. Marshall e que continua a ser o referencial teórico fundamental para a reflexão sobre a cidadania na sociedade contemporânea. Na concepção do conceito estudado por Marshall e explicitado por Saes (2003, p. 10), cidadania é:

...a participação integral do indivíduo na comunidade política; tal participação se manifestando, por exemplo, como lealdade ao padrão de civilização aí vigente e à sua herança social, e como acesso ao bem-estar e à segurança materiais aí alcançados.

Marshall (1967), também nos propõe uma classificação de direitos, que devem ser alcançados para a conquista plena da cidadania, eles seriam "indicadores concretos da cidadania", Saes (2003 p.11). A classificação marshalliana dos direitos seria:

- Os direitos civis, que dizem respeito, principalmente, à liberdade individual, à livre movimentação, ao livre pensamento.

- Os direitos políticos que se ligam a prerrogativa de participar do poder político, ou seja, se tornar membro do governo ou escolher o governo.

- E também os direitos sociais ligados ao acesso mínimo ao bem-estar e seguranças materiais. 
Para Marshall a conquista dos direitos, que são prerrogativas para a conquista da cidadania, seria um processo de conquista natural de direitos "em escada", uma evolução natural, que a crítica feita por Saes (2003) aponta em não levar em conta, por exemplo, os diferentes papéis exercidos pelas classes trabalhadoras, as classes dominantes e a burocracia do Estado na aquisição de direitos e que, carrega consigo conflitos e contradições, visto que, as classes trabalhadoras buscam a conquista de direitos evolucionistas e a classe dominante, juntamente com o Estado, almeja que os direitos concedidos sejam aqueles suficientes para o pleno desenvolvimento do capitalismo.

Nessa análise feita por Saes (2003), através da obra de T. H. Marshall, há uma outra questão abordada e que gerou grande polêmica entre os cientistas políticos, que se refere à relação entre desenvolvimento do capitalismo e evolução da cidadania, onde o autor coloca que a instauração dos direitos civis foi peça fundamental para a implantação e sucesso do capitalismo, pois sem tais direitos as pessoas não poderiam participar livremente do mercado, seja como compradores ou vendedores de sua força de trabalho. A desigualdade social foi também extremamente importante para que as pessoas se dividissem entre capitalistas e empregados, dessa forma, cumprindo uma das exigências do capitalismo.

$\mathrm{Na}$ crítica realizada por Saes (2003) da visão evolucionista da cidadania proposta por Marshall, o autor afirma que na teoria marshalliana não está presente a possibilidade de um salto qualitativo na aquisição de direitos, ou seja, não há a possibilidade de uma "revolução da cidadania". Revoluções como a Revolução Francesa, não são consideradas como alavanques para a conquista de direitos. Há também uma desconsideração das rupturas político-institucionais na implantação e na transformação qualitativa da cidadania e na inexistência da idéia de que "a postura das classes trabalhadoras diante da cidadania, numa sociedade capitalista, tende a ser uma postura dinâmica e progressiva4." A visão marshalliana também ignora que, ao contrário, da postura da classe trabalhadora, a postura das classes dominantes vem no sentido oposto e tende a ser estagnacionista e até regressiva. Para a classe dominante a construção da cidadania visualiza o perigo de uma dinâmica contínua da criação de direitos, onde seus interesses podem ser ultrapassados aos interesses da maioria social.

$4 \quad$ Saes $(2003$, p. 16) 
Temos então, um processo de criação de direitos e cidadania conflituosos, já que os interesses da maioria social são dinâmicos e progressistas e os direitos da classe dominante são estagnacionistas e regressivos.

A crítica de Saes (2003), à visão marshalliana, que propõe reformular o conceito de cidadania proposto por Marshall, se concentra na idéia que o Estado, com o fim do modo de produção feudal absolutista, concede à população a condição de "seres individuais capazes de praticar atos de vontade", ou seja, a capacidade de ir e vir e a capacidade de serem proprietários de bens ou de si mesmos. Isso cria as condições materiais e ideológicas indispensáveis à implantação do capitalismo. A instauração dos direitos civis dá as condições para que se crie o mercado de trabalho, o assalariamento dos trabalhadores despossuídos, que são relações diretas para a constituição do capitalismo. Os direitos civis, dado a todas as pessoas são então indispensáveis para a construção e reprodução do capitalismo. Já os direitos políticos e sociais foram resultado de lutas populares e de pressão sobre a classe dominante e o Estado, para que fossem instaurados. Diferentemente dos direitos civis, os direitos sociais e políticos não são essenciais para a reprodução do capitalismo. Prova disso é que durante anos no Brasil vivemos sob a ditadura militar, onde os direitos políticos nos eram negados e os sistemas eleitorais eram restritivos e antidemocráticos e, mesmo com esse quadro, o país não deixou de ser um país capitalista. Os direitos sociais são até hoje negados à parcela significante da população, que não tem condições dignas de moradia, saúde, educação e que são conseqüências diretas da lógica do capitalismo, que traz em sua essência a desigualdade econômica e social. A busca da classe trabalhadora pela conquista de novos direitos e pela perpetuação de direitos já garantidos por lei, vem para substituir o que os direitos civis prometeram e não cumpriram, graças às exigências do sistema capitalista, que é a realização da igualdade entre os homens.

Há, porém, um agravante na luta das classes populares para aquisição de novos direitos, que está ligada à concentração de recursos políticos, já que a capacidade de pressão da maioria social é inferior a capacidade de pressão dos capitalistas, pois estes concentram o dinheiro, os meios de comunicação, instrução superior, etc.; esta diferença é fruto direto da desigualdade socioeconômica inerente ao capitalismo. A fonte básica dessa superioridade e da desigualdade na concentração dos recursos políticos está ligada a propriedade, ao controle efetivo 
dos bens de produção, que por sua vez é garantido pelo Estado e, mesmo os governos de esquerda, não conseguem romper com essa lógica.

Conforme explicitado por Saes (2003, p. 27), os governos de esquerda, governos populares, adotaram medidas reformistas como a expansão do setor público, a criação de leis sociais ou a adoção de políticas tributárias redistributivas, porém o poder político continuou nas mãos dos grandes bancos, das sociedades financeiras e das grandes empresas industriais. Os governos de esquerda tiveram que se adaptar ao poder político da classe capitalista e não puderam ultrapassar os limites fixados pelos interesses econômicos e políticos dessa classe social.

A dominação política patrimonial, no Brasil, vinculada à questão fundiária que temos presente é camuflada por um sistema moderno que lhe dá um aspecto burocrático-racional-legal, ou seja, a dominação patrimonial está ligada fortemente ao domínio racional-legal que legitima o poder do Estado. A propriedade latifundiária se apresenta como base sólida para a orientação social e política. Essa dominação patrimonial exercida pelas oligarquias políticas de nosso país leva ao controle do Estado e a um domínio político secular. Hoje, sem alianças com as oligarquias nenhum partido político pode governar o Brasil, isso faz com que o clientelismo e a troca de favores sejam intensificados e que estejam sempre presentes nas relações entre sociedade e Estado através do poder público.

Detendo a propriedade e os meios de produção, a classe dominante consegue transformar os rendimentos superiores em recursos políticos, que os ajudam a conquistar cargos políticos, sejam eles municipais, estaduais ou nacionais e também exercer forte pressão sobre as instituições públicas. A detenção da propriedade também significa controle sobre os empregos, que é um elemento decisivo na luta de forças entre a classe dominante e a população.

Segundo, Saes (2003, p.29): a primeira grande limitação ao exercício da cidadania política no capitalismo consiste no fato de que a instauração do sufrágio universal e do regime democrático não implica o estabelecimento de um efetivo controle dos governantes pela maioria social.

Embora, durante as eleições seja à população delegada a escolha de seus representantes, não há um controle social dos governantes durante a efetivação dos mandatos políticos. Pode existir, embora com um grau de coerência bastante reduzido, uma avaliação após o final do mandato, que determina a mudança do voto nas próximas eleições, o que não garante o controle sobre as ações econômicas, 
sociais e políticas realizadas durante a gestão governamental. A ausência de um controle social, do accountability social, explica as infidelidades e o descompromisso dos representantes para com seus representados.

O resultado, na democracia capitalista, de instituições que impõem caráter limitador ao exercício dos direitos políticos e a concentração de recursos políticos nas mãos de uma minoria é, para a maioria social, a apatia política e o conformismo político, que são retratados pelo desinteresse daquilo que é dito político, pelas eleições, pela vida político-partidária e que tem também, grande influência da mídia, principalmente a mídia televisiva, que denuncia as fraudes e corrupções governamentais como atrações de um "circo" sem que haja um mínimo de profundidade e reflexão crítica ao que está posto. Porém, para muitos, este quadro de apatia, desinteresse e conformismo político é o resultado ótimo para o bom funcionamento da democracia.

No entanto, existem também, práticas como o orçamento participativo, que ensejam que a "participação da maioria social no exercício do poder", conforme proposto por Marshall, deva se concretizar. O desafio se concentra em como transformar a apatia e o desinteresse político em organização para a participação política. Práticas participativas, como o $\mathrm{OP}$, mostram que a organização para a participação vem sendo em muitas vezes propostas por governos de esquerda e vislumbram a possibilidade de incorporar as necessidades da maioria social em seus planos de governo, sendo que essa participação ocorre dentro dos limites institucionais, ou seja, de acordo com as normas da democracia representativa e subordinadas à ela.

Uma das propostas do processo do orçamento participativo é justamente a da diminuição das relações clientelistas no município, a partir, do acesso da população a discussão de uma parcela dos investimentos municipais. Esse acesso traria a possibilidade da população priorizar as necessidades do seu bairro ou região e, a partir, da discussão com os demais moradores, definirem o uso dessa verba. A possibilidade de participar é aberta, ou deveria ser em princípio, a qualquer pessoa, qualquer morador, não havendo restrições, independente de a pessoa conhecer ou ter relações com vereadores e/ou prefeito. Visa a mudança, ao menos em partes, das desigualdades dadas.

Nossa sociedade está dominada pelo Estado e pelo modo de produção capitalista, ela é um instrumento dele. A história do Brasil evidência um sistema 
político baseado em relações atrasadas onde a propriedade da terra e o capital moderno - que se consolidou através de um sistema moderno fortemente ligado às relações clientelistas e oligárquicas, extremamente conservadoras - renovam esse sistema e bloqueiam a constituição de uma verdadeira sociedade civil e do exercício da cidadania.

O Estado brasileiro está baseado e fundamentado na política do favor, segundo Martins (1999). Isso não permite a distinção entre público e privado. Por este motivo, inúmeras vezes, nos deparamos com noticiários e escândalos envolvendo políticos que usam recursos e/ou o poder público para benefício próprio ou de familiares e amigos.

A lógica, moral e direito que dão legitimidade ao Estado são práticas que não foram construídas ideologicamente pela sociedade civil. São regras para uma ação prática que quer estruturar a sociedade e as relações que elas estabelecem em um quadro estatista e elitista que garanta o crescimento capitalista e, por isso não é questionado por este modo de produção.

A história de nosso país revela que herdamos essas práticas do período colonial do século XVI. As relações entre público e privado sempre se confundiram e se mesclaram fazendo com que a distinção entre essas duas categorias fosse muito pouco clara para o povo.

Com essa prática de troca de favores tão arraigada em nossa sociedade e vista de maneira tão natural, principalmente pelas populações mais carentes, que obtém muita das prioridades básicas que necessita através dessa ação, fica bastante difícil falarmos de cidadãos e de sociedade civil. Muitos dos deveres, que tinham de ser exercidos pelo setor público, figuram como realização de favores realizados por políticos corruptos para a população e aparecem como se esses políticos estivessem usando de recursos ou bens privados para realizar uma ação que Ihes é obrigatória. São beneficiados pessoas ou grupo de pessoas que mantêm estreitas relações com os eleitos, ou através do compromisso de voto para o candidato a um cargo público. Os bens públicos são usados, desta maneira, como bens privados para trazer benefícios a determinados indivíduos que se utilizam da cultura da troca de favores. Isto ocorre porque o patrimônio pessoal - se é que estes o possuem - já não dá mais conta do eleitorado, devido à democratização cada vez maior do voto. Observa-se que os eleitos para cargos públicos utilizam-se de verbas públicas para cumprirem promessas de campanha ou assegurarem sua reeleição. 
$\mathrm{Na}$ última eleição municipal, alguns moradores do município de Rio Claro/SP, declaravam que a eleição municipal de 2004 foi a eleição da cesta básica. Isto porque, dias antes da votação, ocorrida no dia 03 de outubro, candidatos a vereadores estacionavam caminhões nas ruas dos bairros mais periféricos e mais carentes da cidade e realizaram ampla distribuição de cestas básicas de alimentos com os "santinhos" que continham o número eleitoral e a foto desses candidatos. Essa atitude fez com que candidatos que não eram cotados por pesquisas eleitorais e até mesmo por seus partidos para ocupar a Câmara de Vereadores, mudassem esse quadro.

Observamos que para a nossa sociedade:

Aparentemente, é insuportável para amplas parcelas da população brasileira estabelecer relações sociais de qualquer natureza, políticas ou não, com base unicamente nos pressupostos racionais do contrato social e com base no pressuposto da igualdade e da reciprocidade como princípios que regulam e sustentam as relações sociais. (MARTINS, 1999 p. 43)

A população espera ainda de seus candidatos, a qualquer cargo político, algum benefício em troco do seu voto. $O$ voto não é visto como um importante instrumento para exercício da cidadania. A população, diversas vezes, não tem consciência da importância da valorização do voto e não vê as conseqüências que seu voto traz para o futuro do município e muito menos do estado ou do país. Encara o ato de votar como um compromisso e obrigação moral, sem levar em consideração definições políticas e ideológicas. E por isso, sempre busca algo em troca de seu voto e nunca vê o ato de votar como um direito estabelecido.

\section{Educação e Cultura Política}

O voto popular e as eleições periódicas, que foram grandes conquistas alcançadas com a Proclamação da República e com a declaração dos direitos civis e políticos, não fizeram com que a população participasse ativamente da vida pública. A implementação e a ampliação da democracia participativa pode trazer a apropriação, por parte do povo, da participação na vida política e pública. Não queremos pregar aqui o descarte, nem a diminuição da democracia representativa, que é base para a nossa sociedade atual, o que pretendemos é defender e discutir a coexistência horizontal dessas duas formas de exercício da democracia. Coexistência essa que seria o passo inicial para uma possível efetivação da democracia participativa em toda a sociedade. Em nossa sociedade atual a 
democracia representativa e a democracia participativa devem trabalhar de maneira horizontal e conquistar a igualdade de deveres e direitos para todos os cidadãos de nossos municípios, mesmo apresentando formas diferentes de se exercer a democracia e a cidadania. A população precisa participar e acompanhar o governo que ela elegeu. A autonomia cidadã, a auto-gestão e a soberania popular seriam conquistas futuras após a apreensão da forma de governabilidade acima explicitada, isto porque, hoje a consciência popular da necessidade de participação nos processos decisórios e a educação política são questões ainda embrionárias na sociedade, são questões que devem ser mais bem aprimoradas, melhor divulgadas e articuladas em todos os municípios.

O cidadão só poderá participar inteligentemente da vida democrática com esforço. A democracia requer esforço. O autoritarismo, não; nele é tudo mais rápido e bem mais simples. Mas a democracia é difícil e trabalhosa, de forma que, para se informar, se comunicar e interagir o cidadão tem que se esforçar, deve ter uma disposição genuína para se envolver nas questões de interesse público. Tudo faz parte da educação política. (BENEVIDES, 2003 p. 94)

Esse é o desafio para a população que quer participar, que quer mudar sua realidade através da ação participativa e comunitária, junto à administração pública e quer envolver sua comunidade, seu bairro, sua rua, seus vizinhos e fazer com que essa população perceba que não adianta lutar por interesses próprios, individuais. Fazer com que as pessoas entendam que o exercício da cidadania passa pela solidariedade e pela idéia de que não vivemos isolados. É também um desafio para o poder público que quer agregar seus cidadãos na gestão da cidade, nos processos decisórios, que envolvem os interesses de seu governo e de sua comunidade.

O OP instaura uma nova prática de gestão política, aproveitando as contribuições que podem ser dadas pelos cidadãos e utilizando de maneira mais coerente os recursos públicos municipais, que não tem mais somente seu destino definido apenas pelo gabinete e/ou setor técnico, tem agora uma melhor distribuição, com um efeito redistribuitivo, à medida que as regiões mais pobres são as mais participativas e recebem maior quantidade de recursos.

O orçamento participativo pode ser visto como um aprimoramento da prática cidadã, que muitas vezes é pouco praticado, como uma bem sucedida experiência de participação popular. Nele obtém-se a co-gestão de uma pequena parcela do fundo público; um sistema de partilha de responsabilidades e a redistribuição de 
recursos, mesmo que seja parcial e construída democraticamente entre o poder executivo e a sociedade civil. O OP também possibilita a participação aberta de todos os cidadãos, sejam eles organizados ou não; os próprios participantes devem ter a possibilidade de definir as regras internas do processo; há uma compatibilidade entre as decisões e as regras estabelecidas pela comunidade participante e as exigências técnicas e legais colocadas pelo Estado, tendo sempre que respeitar os limites financeiros, impostos pelo poder público.

O OP traz para a administração municipal um ganho interno, muito importante e até então pouco alcançado, que é a articulação e integração setorial da prefeitura, visto que é um elemento demandado naturalmente pelo processo, devido ao caráter específico do OP, que trabalha com diversos temas e setores administrativos da prefeitura num mesmo processo. Este é mais um desafio, colocado pelo processo, pois a setorização tecnocrática e clientelista que existe em diversas secretarias municipais tendem a ser amenizadas, porque há um trabalho mais integrado que é fundamental para que as obras e serviços reivindicados sejam atendidos. É necessário quebrar os núcleos de poder em que se transformaram alguns setores municipais já que estes possuem a informação que é necessária para que o processo se consolide, isso pode ser conquistado em alguns setores, porém o trabalho junto a educação do funcionalismo público municipal é que irá trazer maiores conquistas nesta direção.

A informação é um outro desafio para a efetivação dos processos de participação popular. É direito do cidadão receber a informação e a comunicação de maneira clara e correta. Num país como o nosso não é exagero afirmar que o que é veiculado pela televisão se confunde com as idéias do poder político, econômico e social. Discutir a televisão é tratar do espaço público, é discutir democracia. Hoje, a televisão é fonte de poder político, com ela as pessoas tornam-se receptáculos, espectadores e ouvintes passivos das idéias vinculadas pelo Estado ou pelas emissoras.

A população recebe informação com pouca qualidade, principalmente a população de baixa renda, que é a população que mais participa das reuniões do OP. Como proceder, como fazer com que essa população tome consciência e compreenda os processos burocráticos e legais que envolvem as ações da prefeitura? Esse é um outro desafio para os governantes: saber trabalhar de maneira clara e transparente para que, aqueles que participam, possam 
compreender todo o processo que envolve a gestão de uma cidade. Dessa maneira os políticos poderiam ter um maior contato com as reais necessidades da população e investir na cidade de maneira mais legítima e mais concreta, as ações partiriam de decisões conjuntas entre a população e o setor político. Porém não podemos nos esquecer dos interesses políticos partidários, que estão presentes em todas as gestões municipais, estaduais e federais e, que na maior parte das vezes não permite essa gestão desinteressada e aberta.

Hoje encontramos a realidade do "cidadão de sofá" que é aquele que assiste à televisão e vota em alguma questão que foi levantada pela TV e que é indiferente a ele, e que nada interfere em sua vida, apenas aperta um botão ou liga para os 0800 e 0300 que são amplamente difundidos em nossa sociedade e "opina"; participa dessa votação sem se preocupar com a busca da boa informação, sem discutir com outras pessoas e sabendo que seu voto não mudará em nada na sua vida. Casos típicos são os programas reality show de televisão.

No mínimo a proliferação da participação popular nas diversas administrações municipais é uma ação concreta contra a arraigada política oligárquica e patriarcal da nossa sociedade. É também a possibilidade de mudança dos costumes e das mentalidades que estão acostumadas com o mando, o favor, o privilégio, a exclusão e o clientelismo. É a possibilidade da transição do "cidadão de sofá" para o cidadão político. A falta de educação política leva a uma imensa proliferação de desorganizados, que agora com o aumento dos espaços públicos de participação popular, podem integrar-se à sociedade como cidadão. A existência desse espaço público de participação é condição indispensável para a democracia, que é exercida através da cidadania. A democracia se constrói a cada dia e envolve processos bastante complexos, envolve o exercício cidadão.

Outro fato marcante é que os processos de participação são importantes para a sociedade, independentemente do resultado prático que eles tragam, porque a educação política é alargada à medida que a população é chamada para conhecer e opinar em assuntos que anteriormente eram de difícil acesso. Mesmo que as pessoas não participem das reuniões, as próprias chamadas para a participação, o material de divulgação distribuído por toda a cidade já tem ação informativa e educativa, a pessoa através dele irá tomar uma posição de aceitar ou não o convite à participação. As reivindicações feitas e que não entram na peça orçamentária também tem papel muito importante porque são discutidas publicamente, são 
esclarecidas questões e dúvidas. As reuniões devem ser um espaço aberto de proposta, reflexão e debate entre a população e o setor executivo que está presente em todas as reuniões do OP e que então, responde as perguntas, ouve as reivindicações, reclamações e as esclarece. Esta é uma grande contribuição para a educação política do cidadão. Todo o processo é um instrumento para a busca da legitimidade política.

O Estado moderno buscando legitimidade política através da racionalidade legal e burocrática incluiu em seu sistema tarefas complexas e técnicas que somente afastou os cidadãos e implantou uma relação autoritária entre governantes e governados. Esta relação causa indiferença e até mesmo a hostilidade da população, em relação, ao que é político e ao que é público e as práticas de democracia participativa desmistificam essa imagem que está vinculada ao político, trazendo a possibilidade de mudança da cultura política e aproximando a população de conhecimentos nacionais e até mesmo internacionais, que afetam seu cotidiano e que antes eles não tinham consciência disto.

Não se pode ter a ilusão que o OP e as demais práticas de democracia participativa acabam com as relações clientelistas e as trocas de favores, mas também não podemos ter uma visão pessimista e pensar que essas ações não interferem em nada nas relações que ocorrem em nossa sociedade. Com essas práticas a cultura política se modifica e vai se consolidando em nosso país de maneira mais justa e mais democrática e cria condições para que a democracia se concretize e avance no sentido da justiça e da igualdade social. O povo passa a ter papel de destaque central em nossa sociedade. 


\section{Considerações Finais}

O espaço urbano é produto, condição e meio da reprodução das relações sociais. Ele é produzido histórica e socialmente e, por isso, o espaço não se apresenta apenas como quadro físico ou palco para a realização das relações sociais. "As relações sociais se materializam enquanto relações espaciais, concretamente na cidade." (CARLOS, 2005 p. 224).

A mesma cidade que é produzida socialmente, é apropriada privativamente, sendo resultado do processo de reprodução do modo de produção capitalista, que transforma a cidade em mercadoria. O solo urbano passa a ser utilizado como objeto de troca, em detrimento do uso, logo, o uso encontra-se em segundo plano e é o mercado consumidor, apoiado pelo Estado e seu poder político, que dita as regras para ocupação do espaço urbano. A reprodução continuada do ciclo do capital faz com que o mercado defina o uso dos lugares da cidade e determine o tipo de ocupação que cada lugar irá receber. Assim, a posição que o indivíduo ocupa no mercado de trabalho determinará o lugar que ele ocupará na cidade e quais bens e serviços urbanos ele receberá.

A análise realizada nesta dissertação sobre a produção do espaço urbano da cidade de Rio Claro e a evidência trazida por um processo de participação popular, mostrou a existência de um espaço produzido desigualmente e carregado de contradições. Mostrou a desordem da cidade e como a população encontra alternativas para se reproduzir e viver nesse espaço.

O orçamento participativo, que é o processo de participação popular analisado nesta dissertação, foi implantado pela prefeitura municipal de Rio Claro, assim como em outras prefeituras brasileiras, na tentativa de aproximar o poder público da sociedade e de administrar a carência na cidade. A privação dos habitantes à educação, saúde, trabalho é o que movimenta o processo do OP, é o que faz com que as pessoas saiam de suas casas e debatam seus problemas, que são enfrentados cotidianamente.

Os diversos processos de participação popular emergidos no mundo nas últimas décadas têm motivações comuns entre si. Bacqué, Rey e Sintomer (2005, p.304) apresentam três motivações principais:

1. A crise pela qual passa a democracia representativa. Santos (2006) afirma que "os cidadãos se sentem cada vez menos representados pelos seus 
representantes e acham que as decisões mais importantes dos seus governos escapam à sua participação democrática";

2. Um questionamento da ação pública tradicional;

3. Uma impulsão causada pela mundialização neoliberal.

Bacqué, Rey e Sintomer (2005, p.306) apontam que os dispositivos participativos apresentam também expectativas e interesses diversos. Existem casos em que são os funcionários públicos que desejam reformar a burocracia pública e abrir o Estado para que este não dependa mais dos mecanismos do mercado; há os que são impulsionados por movimentos sociais militantes que buscam uma democracia radical e uma outra maneira de produzir e repartir as riquezas; há os dispositivos participativos que interessam a organismos internacionais, caso do Banco Mundial; há os representantes políticos que buscam nova legitimidade; e ONG's que buscam mudanças através da ética da solidariedade.

Já Carlos (2005 p.240) afirma que na realidade a gestão democrática é "condição da reprodução capitalista em seu novo estágio de desenvolvimento" e aponta que o “objetivo é permitir o 'ajustamento' das economias em desenvolvimento às necessidades de expansão do neoliberalismo." O que convergiria com um dos apontamentos feitos por Sintomer (2005 p.306).

No caso do orçamento participativo, especificamente da cidade de Rio Claro, nos parece que o objetivo inicial foi o de aproximação maior com a sociedade, na busca por uma nova legitimidade do poder público municipal e o compartilhamento da gestão da carência na cidade. É claro que o interesse de organismos internacionais, como o Banco Mundial, em práticas participativas e especialmente no orçamento participativo, nos leva a uma série de questionamentos e nos leva a afirmação de Carlos (2005, p. 240) segundo a qual a gestão democrática da cidade estaria produzindo um ambiente propício à reprodução da lógica neoliberal.

Continuando neste mesmo raciocínio, de reprodução da lógica neoliberal, voltamos para uma questão colocada no início desta dissertação, que se refere ao sucesso alcançado pelo OP comparado aos outros processos de participação popular. Este sucesso não tem estreita relação com o sistema de produção capitalista? O OP discute orçamento para investimentos na cidade, ele dá a oportunidade, que talvez seja a única, para que a população reivindique melhorias para a sua região. Ele diz respeito à gestão de recursos frente a um espaço, que é a cidade, onde se deve administrar a carência. Ao mesmo tempo, o processo supre 
uma carência, resultado do processo privado de apropriação da cidade e que produziu um espaço desigual e até mesmo desumano, onde as pessoas não exercem nem seus direitos civis, nem sociais. A população participa porque está no limite da sobrevivência, vive uma vida degradada, em espaços degradados e não tem consciência política do processo. A participação é mediada pela reinvindicação.

É necessário que exista extremo cuidado ao tratar com afirmações feitas por teóricos, que apontam a gestão democrática da cidade como revolucionária, emancipatória e libertadora. A proclamada conquista da cidadania foi apropriada pelo discurso neoliberal e é utilizada por diversos elementos da sociedade e, então hoje, qualquer ação solidária é aclamada como conquista cidadã. A banalização do conceito faz com que muitos pesquisadores o abandonem.

A cidadania foi discutida durante esta dissertação baseada na teoria de Marshall (ano), tomando como pressuposto que ela se concretiza com a conquista dos direitos civis, políticos e sociais. Essa teoria é contestada por autores como Saes, (2003) e Carvalho (2004) que acreditam que a cidadania possa se efetivar sem a conquista destes três direitos, mas ela só será exercida plenamente fora do sistema capitalista. Heller (1983, p. 143 apud CARLOS, 2005, p. 241) aponta que a cidadania é um dos carecimentos radicais criados pelo capitalismo e este carecimento só poderá ser satisfeito com a superação da sociedade capitalista.

E assim como a cidadania, a democracia plena também dificilmente poderá ser alcançada dentro do sistema capitalista. Santos (2006) afirma que quem melhor definiu o ideal de democracia foi Rousseau e esta definição hoje entra em conflito com as democracias reais. "Uma sociedade só é democrática quando ninguém for tão rico que possa comprar alguém e ninguém seja tão pobre que tenha de se vender a alguém." Seguindo este critério e se nos basearmos no exposto nesta dissertação, percebemos que estamos longe de alcançar esta democracia.

Santos (2006) aponta quatro principais desafios para que a democracia se efetive:

1. Diminuição das desigualdades sociais entre ricos e pobres, para que o ideal republicano de igualdade jurídico-política não se torne uma hipocrisia social constitucionalizada;

2. O reconhecimento da diversidade cultural;

3. O bloqueio das imposições econômicas e militares dos países dominantes, que são cada vez mais drásticas e menos democráticas e; 
4. Condições de participação democrática aos cidadãos, para superar esse último desafio são necessárias três condições: a garantia de sobrevivência, a liberdade e a informação.

Afirmar que os processos de participação popular, em especial o OP, são efetivações da democracia e da cidadania é equivocado. Frente às constatações que apresentamos, a real efetivação destes dois elementos se torna praticamente impossível dentro do sistema de produção capitalista. Verificamos que o OP avança em relação ao que estava posto no sistema político das cidades, que era o total afastamento das decisões públicas em relação à sociedade. $O$ resultado deste distanciamento, praticado durante décadas na administração pública, pode ser visto na análise das regiões da cidade, realizada nesta dissertação. Encontramos grandes desigualdades na paisagem urbana e na população que ocupa essas regiões. As reivindicações feitas nas reuniões do OP nos ajudaram a revelar o quão cruel são as desigualdades e o quão perverso é o sistema capitalista, que na sua ação de apropriação privada e especulação do solo urbano, expulsa para as periferias mais distantes e degradadas a população mais carente. Carência esta causada pela inexistência da propriedade privada e que, então, é ainda mais dificultada pelo não acesso à alimentação, à educação e à saúde, que são elementos básicos para a reprodução desta população.

O processo do orçamento participativo garante à população a oportunidade de exercer alguns direitos, como o de exercício político e a luta por direitos sociais. Porém a noção de direito que está contida no processo do OP é o de direito a discutir, direito de morar e de reivindicar serviços públicos básicos para a sua vida. "É o 'direito a cidade' que o Estado está disposto a ceder para a gestão da cidade." (CARLOS, 2005, p. 4). Há uma compreensão limitada do direito a cidade, onde o habitar em sua dimensão plena é deixado de lado.

Sentidos como "dignidade, distribuição, festa, poesia, alegria de viver que é o sentido último da idéia de direito a cidade exposto por Henri Lefebvre" expostos por Carlos (2005, p. 7) estão para além da sociedade capitalista e não contemplados nos atuais processos de participação popular.

Portanto, se analisarmos somente o processo do orçamento participativo implantado na cidade de Rio Claro, durante o período 1998 a 2004 - ele começa a ser executado no segundo ano do primeiro mandato - podemos identificá-lo como um momento ímpar na cidade, onde a população pôde se aproximar da gestão 
administrativa municipal e participar de decisões acerca de uma parcela do orçamento municipal. Foi um período diferente na história da cidade, em que as contradições espaciais se evidenciaram e a produção desigual, que valoriza a propriedade privada em detrimento ao uso da cidade, ficaram evidentes.

Porém o processo do OP na cidade de Rio Claro, após o término do governo de 1997 a 2004, terminou e aparentemente não deixou vínculo com a população, pois em nenhum momento houve manifestação destas pessoas, nem mesmo dos conselheiros do OP, com a extinção do processo e o abandono de suas decisões. Isto dá ao processo do OP o caráter de um momento onde existiu a gestão diferenciada do governo municipal. Foi um momento de abertura para a prática democrática, onde as pessoas puderam opinar, decidir e participar da administração da cidade e os governantes puderam conhecer as expectativas e demandas sociais diretamente. No entanto, este momento evidencia também a descontinuidade das políticas públicas, que ficam dependentes totalmente da vontade política dos governantes e de seu compromisso político junto à população. A população sem conseguir se mobilizar e formar um movimento social reivindicatório fica a mercê das trocas de poder, que acontecem nos setores públicos.

O que expusemos nesta dissertação é uma análise realizada sobre uma experiência vivida que trouxe para nós a revelação das contradições existentes no espaço urbano e a segregação da sociedade, que são resultado do desenvolvimento desigual das relações capitalistas de produção. A dinâmica e as constantes transformações do espaço revelam a necessidade de compreensão deste momento real e cabe ao geógrafo desvendar este movimento constante. Esta dissertação traz uma contribuição na reflexão sobre a produção do espaço e suas possibilidades. Há ainda um longo percurso a ser trilhado na busca da elucidação das dinâmicas espaciais, que são construídas socialmente. 
ALFOSIN, B. M. e MOTTA, J. - Gestão democrática em Porto Alegre: dificuldades e oportunidades para avançar uma experiência exitosa. Disponível em: $\quad<h t t p: / / w w w . u r b a r e d . u n g s . e d u . a r / e x p e r i e n c i a s-p r e s e n t a c i o n . p h p ?$ expid=2> Acesso em 04 de novembro de 2005.

BACQUÉ, M. H.; REY, H. ; SINTOMER, Y. - Gestion de proximité et démocratie participative : une perspective comparative. Paris : La Découverte, 2005.

BARBOSA, J. L. e LIMONAD, E. - Entre o ideal e o real rumo a sociedade urbana algumas considerações sobre o "Estatuto da Cidade". Revista GEOUSP - Espaço e Tempo, FFLCH/USP n 13, 2003.

BENEVIDES, M.V.; KERCHE, F. e VANNUCHI, P. (orgs.) - Reforma Política e Cidadania. São Paulo: Perseu Abramo, 2003.

BILAC, Maria Beatriz Bianchini - As Elites Políticas de Rio Claro: recrutamento e trajetória. Piracicaba/Campinas: Unimep/Unicamp, 2001.

BONDUKI, Nabil - A Luta pela Reforma Urbana no Brasil: do regime militar à criação do Ministério das Cidades. In. Memória do VI Seminário Internacional da Unidade Temática de Desenvolvimento Urbano. Buenos Aires, 2003.

BRASIL. Lei $\mathbf{n} . \mathbf{1 0 . 2 5 7}$, de 10 de julho de 2001. Regulamenta os artigos 182 e 183 da Constituição Federal, estabelece diretrizes gerais da política urbana e dá outras providências. Disponível em: <http://www.planalto.gov.br/ccivil/LEIS/LEIS_2001L10257.htm.> Acesso em: diversos acessos.

CABANNES, Yves (coord.) - Financiamento Local e Orçamento Participativo. Porto Alegre. Documento de Base - Rede 9 / Urb-AL - Prefeitura de Porto Alegre, 2004.

CANETTI, Elias - Massa e Poder. São Paulo: Companhia das Letras, 1995.

CARLOS, Ana Fani Alessandri - A ( $R$ e) produção do Espaço Urbano: o caso de Cotia. São Paulo. Tese de Doutorado - USP, 1987.

- O lugar no/do mundo. São Paulo: Hucitec, 1996.

- A Cidade. São Paulo: Contexto, $3^{\mathrm{a}}$ edição, 1997.

- Espaço-tempo na Metrópole: a fragmentação da vida cotidiana. São Paulo: Contexto, 2001. 1ª edição, 2004.

- O Espaço Urbano: novos escritos sobre a cidade. São Paulo: Contexto, 
CARLOS, Ana Fani Alessandri - La utopía de la "gestión democrática de la ciudad". In. VII Coloquio Internacional de Geocrítica "Los agentes urbanos y las políticas sobre la ciudad" - Santiago de Chile, 24 - 27 de mayo 2005. Disponível em:<hhtp://64.4.51.250/cgibin/getmsg/textoFani.htm?curmbox=00000000\%2d0000\% 2d00... >. Acesso em 01 de junho de 2005.

CARVALHO, José Murilo - Cidadania no Brasil: o longo caminho. Rio de Janeiro: Civilização Brasileira, 2004.

COSTA, Sergio - Movimentos Sociais, Democratização e a Construção de esferas públicas locais. In. Revista Brasileira de Ciências Sociais, vol. $12, n^{\circ} 25$, fevereiro 1997.

DIAS, Márcia Ribeiro - Sob o Signo da Vontade Popular: o Orçamento Participativo e o dilema da Câmara Municipal de Porto Alegre. Belo Horizonte: Editora UFMG, 2002.

DIAS, Romualdo - Democracia Participativa em Rio Claro, Brasil. Quito: Cuaderno de Trabajo, 109: PGU - UN-HABITAT, marzo 2003.

GENRO, Tarso e SOUZA, Ubiratan de. - Orçamento Participativo: a experiência de Porto Alegre. São Paulo: Perseu Abramo, $3^{\circ}$ edição, 1997.

GODOY, T. M. P. de - O Espaço da Produção Solidária dos Catadores de Materiais Recicláveis: usos e contradições. Dissertação de Mestrado, IGCE/UNESP, Rio Claro, 2005.

LE GOFF, Jacques - Por Amor às Cidades. São Paulo: Editora UNESP, 1998.

LEFEBVRE, Henri - O Direito à Cidade. São Paulo: Centauro, $1^{\text {a }}$ edição, 2001.

LUCCA, C. S. T. et alli. - Aspectos da Expansão Urbana de Rio Claro : renda da terra e o poder político. Trabalho de Graduação. UNESP/IGCE/DPR, Rio Claro, 1981.

MARTINS, José de Souza - O Poder do Atraso: ensaios de sociologia da história lenta. São Paulo: Hucitec, $2^{a}$ edição, 1999.

MARSHALL, T. H. Cidadania e classe social. In: Cidadania, classe social e status. Rio de Janeiro: Zahar, 1967.

PINTAUDI, Silvana - Participação Cidadã e Gestão Urbana. Revista Cidades. Presidente Prudente, vol. 2, n² 2, julho 2004.

- Participación Ciudadana en la Gestión Pública: los desafíos políticos. In. VII Coloquio Internacional de Geocrítica "Los agentes urbanos y las políticas sobre la ciudad" - Santiago de Chile, 24 - 27 de mayo 2005. Disponível em: $<$ hhtp://64.4.51.250/cgibin/getmsg/textoSilvana.htm?curmbox=00000000\%2d0000\%2...>. Acesso em 01 de junho de 2005. 
PIZZIRANI, Fabiane - Rio Claro: o exercício da democracia participativa através do Orçamento Municipal. 2001. Trabalho de Graduação. Universidade Estadual Paulista, Rio Claro, 2001.

RONCAYOLO, Marcel - La Ciudad. Barcelona : Ediciones Paidos, 1988 - La ville et ses territoires. Paris : Gallimard, 1990

SAES, Décio. Cidadania e capitalismo: uma crítica à concepção liberal de cidadania. Crítica Marxista, São Paulo, Boitempo, n 16, p. 9-38, março 2003.

SANTOS, Boaventura de Sousa (org.) - Democratizar a democracia: os caminhos da democracia participativa. Rio de Janeiro: Civilização Brasileira, 2002.

- 0 Futuro da Democracia. Disponível em: <http://cartamaior.uol.com.br/templates/colunaMostrar.cfm?coluna_id=3302>. Acesso em 06 de setembro de 2006.

SANTOS, Milton - Metrópole Corporativa Fragmentada: o caso de São Paulo. São Paulo: Studio Nobel, 1990.

SARAMAGO, José - Desventuras em série. São Paulo. In: Revista Epoca, edição 389, 31/10/2005.

SARTORI, Giovanni - Homo videns: televisão e pós-pensamento. Bauru: EDUSC, 2001.

SILVA, F. M. A. da - A Expansão da Malha Urbana de Rio Claro: suas implicações histórico-geográficas (1835-1984). Trabalho de Graduação. UNESP/IGCE/DPR, Rio Claro, 1984

SOUZA, Celina - Construção e consolidação de instituições democráticas: papel do orçamento participativo. In. São Paulo em Perspectiva, vol. $15, n^{\circ} 4$. São Paulo, outubro/dezembro 2001. Disponível em: <http://www.scielo.br/scielo.php>. Acesso em 12 de julho de 2006.

SOUZA, Marcelo Lopes de - Mudar a Cidade: uma introdução crítica ao planejamento e gestão. Rio de Janeiro: Bertrand Brasil, 2002.

SLOTERDIJK, Peter - No Mesmo Barco: ensaio sobre a hiperpolítica. São Paulo: Estação Liberdade, 1999.

- O Desprezo das Massas: ensaio sobre lutas culturais na sociedade moderna. São Paulo: Estação Liberdade, 2002. 


\section{Glossário dos Partidos Políticos}

PV - Partido Verde. Fundação em 17 de janeiro de 1986.

PT - Partido dos Trabalhadores. Fundado em 10 de fevereiro de 1980.

PMDB - Partido do Movimento Democrático Brasileiro. Fundado em 24 de março de 1966.

PC do B - Partido Comunista do Brasil. Fundado em 18 de fevereiro de 1962, após a cisão com o Partido Comunista Brasileiro (PCB).

PPS - Partido Popular Socialista. Fundado em 1992. Substitui o PCB.

PDT - Partido Democrático Trabalhista. Fundado em 17 de junho de 1979.

PSC - Partido Social Cristão. Fundado em maio de 1985. 